\title{
De constitutionele positie van politieke partijen in Nederland
}

\author{
Met een toegift over hun constitutionele positie in de \\ Europese Unie
}

Bettie Drexhage en Remco Nehmelman ${ }^{1}$

I De vraagstelling en wat daarbij verder komt kijken

I.I Inleiding

Al meer dan een eeuw wordt de Nederlandse politiek gedomineerd door politieke partijen, maar in het positieve staatsrecht komen we ze eigenlijk niet tegen. In sommige landen is dat anders. De European Commission for Democracy through Law van de Raad van Europa (Venice Commission) onderscheidt op dit punt twee tradities:

'(...) The first one defines a political party as a free association of individuals, with minimal state regulation, oversight, financial support etc (UK experience) or it may be that of a specific association with precise duties, responsibilities and prerogatives (German model). Parties in Europe have evolved from one or other concept and are on a converging path, but cultural differences are still significant. Hence, in many countries, any state regulation is still seen as interference, whilst in others there is less hesitation about political engineering through party law, registration procedures etc.' ${ }^{2}$

De Nederlandse benadering komt uit de als eerste genoemde traditie. Toch zijn de partijen sinds de jaren zeventig van de vorige eeuw met een toenemend aantal overheidsregels geconfronteerd door achtereenvolgens de introductie van subsidies, ${ }^{3}$ het nieuwe rechtspersonenrecht in het Burgerlijk Wetboek ${ }^{4}$ en de herziening van de Kieswet. ${ }^{5}$ In dit verband is wel gesproken van 'sluipende constitutionalisering', in weerwil van tegelijkertijd bij herhaling ingenomen standpunten waarin regulering

I Betty Drexhage is ambtenaar bij de afdeling Constitutionele Zaken van het Nederlands ministerie van Binnenlandse Zaken en Koninkrijksrelaties. Remco Nehmelman is universitair hoofddocent Staats- en Bestuursrecht bij de Universiteit Utrecht.

2 Venice Commission 2006.

3 Vanaf 1972 . Zie paragraaf 6.

4 In 1976 . Zie paragrafen 4 en 5.

5 In Ig89. Zie paragraaf 4. 
van politieke partijen principieel van de hand werd gewezen. ${ }^{6}$ Het lijkt een bevestiging van de constatering van de Venice Commission dat de verschillen tussen landen kleiner worden, maar dat de uiteenlopende grondhoudingen herkenbaar blijven.

Ook de staatsrechtelijke literatuur over ons onderwerp is betrekkelijk karig. Sinds het proefschrift van Elzinga uit $\mathrm{I}_{982}$ is geen omvattende studie naar de staatsrechtelijke positie van politieke partijen verschenen. ${ }^{7}$ De literatuur die er is, is verspreid en deels achterhaald. Alleen al daarom is het een goed moment om weer een keer de balans op te maken. Wij zien daarvoor nog twee andere redenen. Ten eerste werd het eerste decennium van deze eeuw gekenmerkt door nogal wat rumoer aan het Nederlandse partijenfront, waardoor vragen rond de interne organisatie en de financiering van partijen, de verhouding tussen partij en volksvertegenwoordiger en het partijverbod opnieuw op de politieke agenda kwamen. Ten tweede werd er de afgelopen tijd druk uitgeoefend vanuit internationale organen om de Nederlandse wetgeving over politieke partijen en de uitvoering daarvan aan internationale maatstaven aan te passen. Het ging daarbij om gespecialiseerde organen die zich bezig houden met respectievelijk het tegengaan van corruptie ${ }^{8}$ en de naleving van het Vrouwenverdrag van de Verenigde Naties. ${ }^{9}$ De rol die dit type organen speelt in het aanjagen van nationale discussies is een betrekkelijk nieuw fenomeen dat een impuls kan blijken te zijn voor verdere convergentie van nationale rechtsstelsels en dus, in ons geval, voor verdere 'sluipende constitutionalisering' van politieke partijen in Nederland. Hoewel hun aanbevelingen niet bindend zijn, gaat er een aanzienlijke druk van uit doordat regeringen zich moeten verantwoorden en doordat nationale pressiegroepen er een handvat aan ontlenen.

Wij willen hierna proberen in kaart te brengen op welke punten de Nederlandse wetgeving zich meer of juist minder met het fenomeen politieke partij zou moeten inlaten teneinde hun constitutionele positie, of die van anderen ten opzichte van hen, te waarborgen of te veranderen. Daarvoor zijn nodig: een uiteenzetting over wat wij meer precies verstaan onder 'de constitutionele positie van politieke partijen', een afbakening van ons onderwerp en een plan van aanpak, benevens enkele normatieve uitgangspunten op basis waarvan wij kunnen beredeneren of de huidige wetgeving nog voldoet.

\section{I.2 Het onderwerp}

Dat de politieke partijen in het staatsrecht nauwelijks voorkomen, wil niet zeggen dat ze geen staatsrechtelijke (constitutionele) positie hebben. Enerzijds wordt die positie bepaald door hun relatie met de Staat, waarin de verenigingsvrijheid centraal staat maar waar soms ook in die vrijheid kan worden ingegrepen. Anderzijds

6 Koole i992, hoofdstuk 6.

$7 \quad$ Elzinga 1982.

8 Group of States against Corruption (GRECO), zie paragraaf 6.

9 Committee on the Elimination of Discrimination against Women (CEDAW). Zie paragraaf 4 . 
wordt die positie bepaald door de grenzen die aan de werkzaamheden van politieke partijen worden gesteld door de staatsrechtelijke positie van anderen: de kiezers en de overheidsambten bij de bemensing waarvan de partijen een rol spelen en op wier werkzaamheden ze invloed uitoefenen. Over deze relaties gaat dit preadvies.

De eerste vraag die zich daarbij aandient, is of de rol die politieke partijen in deze relaties spelen, niet aan sterke verandering onderhevig is. Wat in dit verband te denken van de ontwikkelingen die worden gesignaleerd in de sociologische en politicologische literatuur over politieke partijen: sterk afgenomen ledenaantallen en de teloorgang van een deel van de (veelheid aan) 'functies' die wel aan partijen is toegedacht, waarbij de ideaaltypische 'massapartij-uit-de-hoogtijdagen-van-de-verzuiling' als referentiekader dient. ${ }^{\mathrm{IO}}$ Die ontwikkelingen kunnen niet worden ontkend. Ze hebben de positie van politieke partijen veranderd, maar per saldo niet verzwakt. Het tegendeel kan zelfs goed worden volgehouden. ${ }^{\text {II }}$ Politieke partijen blijven onontbeerlijk voor het functioneren van een representatieve democratie in elke enigszins complexe samenleving. ${ }^{12}$ Dit is niet alleen een empirisch gegeven, het kan ook beredeneerd worden. Politieke groepsvorming is ten eerste nodig om kandidaten aan te dragen voor overheidsambten, zeker in een kiesstelsel als het Nederlandse, dat is gebaseerd op evenredige vertegenwoordiging. Wil het daarbij ook tot een vorm van verantwoording tegenover de kiezers komen, dan moet die groepsvorming bovendien enige permanentie hebben. Daarnaast is groepsvorming op basis van inhoudelijke argumenten en standpunten in het parlement onmisbaar voor de organisatie van meerderheden teneinde tot besluitvorming te komen. Die besluitvorming is noodzakelijk omdat een volksvertegenwoordiging een besluitvormend orgaan van de overheid is, en niet alleen maar een spreekbuis van de bevolking tegenover de overheid. Een gemeenteraad in een kleine homogene gemeente laat zich nog wel denken als een verzameling wijze mensen die naar bevind van zaken beraadslaagt en beslissingen neemt, maar een nationaal parlement zou op zo'n manier machteloos zijn, omdat het niet een functionerende regering in het zadel zou kunnen helpen en houden en het evenmin tot zinvolle en begrijpelijke wetgeving zou kunnen komen. ${ }^{13}$ Via de constructie van meerderheden in het parlement op basis van inhoudelijke standpunten en, in een parlementair stelsel als het onze, via de vorming van een regering met een regeerprogramma kan een verbinding worden gelegd met de door de verschillende groeperingen aan de kiezers voorgelegde (pakketten van) politieke keuzen. Om het noodzakelijke verband tussen al deze zaken te bewaren is doelgerichte organisatie nodig. Dat is waarin politieke partijen in de praktijk ple-

Io Zie Raad voor het openbaar bestuur 2009 en de daar vermelde literatuur.

II Koole 2006b.

I2 Over de vraag of we het in Nederland in de toekomst ook wel zonder partijen kunnen stellen o.a.: Voerman I994, Tromp 2002 en Elzinga 2004.

I3 Goodin 2008. Zie daarin paragraaf Io.I met als titel No-party democracy, waarin de auteur ook uiteenzet dat politiek zonder partijen meer personalistisch en cliëntelistisch zou zijn, meer gebaseerd op patronage en op demografische onderscheidingen en belangen en dat het daarin vooral over bestuurlijke zaken zou gaan en niet over politieke keuzes. 
gen te voorzien. Voor zover wij weten heeft nog nooit iemand een goed alternatief daarvoor bedacht en komt dit in de wereld ook niet in duurzame vorm voor. ${ }^{\mathrm{I4}}$

De in de sociologische en politicologische literatuur geschetste ontwikkelingen zijn relevant voor het staatsrecht, maar bij de gedachtevorming over het specifieke onderwerp van de constitutionele positie van de politieke partijen, bleek het geen noemenswaardig verschil te maken of wij deze nu wel of niet in de beschouwingen betrokken. Dat komt deels doordat de staatsrechtelijke blik precies op die 'functies' focust die het minst ter discussie staan: de rekrutering van bestuurders en volksvertegenwoordigers en het formuleren van een politiek programma. Het komt ook doordat het centrale vraagstuk in dezen, namelijk de vraag of de toegang van burgers tot de politieke besluitvorming vergroot moet worden of anders moet worden georganiseerd, ons onderwerp te buiten gaat. De voorstellen die in dat verband wel worden gedaan, zoals referenda en burgerfora, het burgerinitiatief, participatieve en deliberatieve besluitvormingsprocedures, zijn alle relevant, zowel voor het staatsrecht als voor de positie van politieke partijen, maar daarop in te gaan zou een geheel andere en vooral ook een veel omvangrijker opzet (en veel meer tijd van uw preadviseurs) hebben gevergd, terwijl het er in Nederland bovendien niet naar uitziet dat op dit punt in de komende tijd daadwerkelijk doorbraken zullen plaatsvinden. ${ }^{15}$ Wij laten deze invalshoek daarom in dit preadvies buiten beschouwing.

\section{I.3 Afbakening en plan van aanpak}

Wij definiëren een politieke partij als: een groepering die zich heeft georganiseerd teneinde kandidaten te stellen voor verkiezingen voor publieke ambten en die dat ook daadwerkelijk doet. ${ }^{16}$ In Nederland gaat het daarbij uitsluitend om de verkiezing van volksvertegenwoordigers, zowel landelijke als provinciale en gemeentelijke. ${ }^{17}$ Daartoe zullen wij ons dan ook beperken, en daarbinnen eenvoudshalve tot de nationale volksvertegenwoordiging, tenzij anders vermeld. Voor de Belgische lezers voegen wij hieraan toe dat het Nederlandse parlement uit twee kamers bestaat, waarvan de Tweede Kamer, die via rechtstreekse verkiezingen wordt samengesteld, verreweg de belangrijkste is. Onze senaat, Eerste Kamer genaamd, wordt getrapt gekozen door de provinciale volksvertegenwoordigers en heeft minder bevoegdheden.

Bij onze onderwerpkeuze zijn we pragmatisch te werk gegaan. Al gauw was duidelijk dat een aantal thema's aan de orde zou moeten komen, omdat juist daarover in Nederland discussie bestaat. Die thema's te behandelen binnen de ons toegemeten ruimte, leek al een zodanige opgave, dat we hebben afgezien van een meer systematische aanpak. We gaan dus in de volgende paragrafen nagenoeg onmiddellijk over

\footnotetext{
I4 Over representatie zonder partijen: Lucardie $200 \mathrm{I}$.

I5 Voor een belangrijk deel doordat veel politieke partijen er een bedreiging van hun eigen positie in lijken te zien.

I6 Vergelijk Koole I992, p. I8 en Venice Commission 2004.

I7 Strikt genomen moeten we hier ook de waterschappen noemen, maar die betrekken we niet in ons betoog, omdat dat een verhaal apart is en omdat hun voortbestaan bovendien onzeker is.
} 
tot een thematische behandeling van achtereenvolgens de verhouding tussen partij en volksvertegenwoordiger (paragraaf 3), de interne organisatie van politieke partijen (paragraaf 4), het partijverbod (paragraaf 5) en de financiering van politieke partijen (paragraaf 6). Dit wordt alleen nog voorafgegaan door een historische paragraaf over het Nederlandse staatsrecht en de politieke partijen (paragraaf 2). Van een algemene slotbeschouwing zagen wij af, omdat de thematische paragrafen elk hun eigen conclusies bevatten. Wel volgt na paragraaf 6 nog een korte toegift over de constitutionele positie van politieke partijen in de Europese Unie (paragraaf 7).

De thematische paragrafen hebben steeds eenzelfde opbouw. ${ }^{\mathrm{I}} \mathrm{Na}^{\mathrm{N}} \mathrm{een}$ korte introductie van de thema's, zetten wij eerst het relevante positieve recht uiteen. Vervolgens gaan wij in op de praktijk en ten slotte gaan wij over tot de behandeling van de vraag of de wetgeving nog voldoet, dan wel gewijzigd zou moeten worden of een andere toepassing zou moeten krijgen. Om die laatste paragrafen te kunnen schrijven hebben wij enkele normatieve uitgangspunten gehanteerd. Daarover gaat de volgende paragraaf.

\section{I.4 Vier normatieve uitgangspunten}

Volgens goed of althans ruimtebesparend gebruik in de juridische literatuur zullen wij in ons betoog zo nu en dan een beroep doen op normatieve overwegingen die wij niet allemaal vooraf hebben afgeleid en gesystematiseerd. Vier uitgangspunten willen we echter vooraf benadrukken, omdat ze bij verschillende thema's een rol spelen en omdat we ze belangrijk vinden.

Het eerste uitgangspunt is de notie dat het streven naar politieke machtsverwerving legitiem is in een democratie. Daarbij maakt het in beginsel geen verschil of dat gebeurt om de zittende macht te ondersteunen of om die omver te werpen, het bestaande rechtsstelsel te behouden of het door iets heel anders te vervangen: ook afwijkende maatschappijopvattingen en radicale voorstellen moeten in beginsel een kans krijgen in het politieke debat te worden gehoord. Hieruit leiden wij af dat grote terughoudendheid moet worden betracht bij het ingrijpen in de vrijheid van vereniging van politieke partijen. Dat geldt niet alleen voor de opvattingen, maar ook voor de organisatie van een politieke partij, die niet los gezien kan worden van de inhoudelijke opvattingen. Inherent daaraan is dat er altijd nogal wat mensen zullen zijn, waaronder juristen die in vakbladen publiceren, die bepaalde politieke groeperingen met afschuw gadeslaan én die soms ook om ingrijpen door bestuur, rechter of wetgever zullen vragen. Het zou verbazend zijn als dat niet zo was, maar het betekent dus ook niet zoveel. Ingrijpen ligt niet gauw voor de hand en het zwaarste middel, een partijverbod, is alleen toelaatbaar als de grondslagen van de democratische rechtsstaat daadwerkelijk dreigen te worden aangetast. ${ }^{19}$

I8 Alleen paragraaf 6 kent een extra subparagraaf.

I9 Zie o.a. Burkens 200I, p. 20I-202. 
Het tweede uitgangspunt is een notie die onder andere tot uitdrukking komt in de zuiveringseed die volksvertegenwoordigers bij hun aantreden dienen af te leggen en in de regels over stemonthouding en openbaarmaking van nevenfuncties, namelijk dat politieke macht niet te koop mag zijn. Bij verkiezingen weegt elke stem even zwaar en de kiezers moeten ervan kunnen uitgaan dat de personen waarop zij een stem uitbrengen, staan voor (een visie op) het algemeen belang en dat zij niet op de achtergrond en onzichtbaar worden gestuurd door heel specifieke belangen van maatschappelijk of economisch machtige personen of organisaties. Hieruit leiden wij af dat partijen noch kandidaten financieel afhankelijk mogen zijn van concrete belanghebbenden bij de politieke besluitvorming. Op zijn minst moeten dergelijke relaties zichtbaar worden gemaakt, zodat de kiezer er rekening mee kan houden bij het uitbrengen van zijn stem.

Ons derde uitgangspunt vloeit voort uit de hierboven betoogde noodzaak van groepsvorming in het parlement en van een relatie tussen die groepsvorming en de standpunten van politieke partijen. Dit betekent dat wij het in de literatuur vaak impliciet nog rondwarende ideaal van de volstrekt onafhankelijke volksvertegenwoordiger die tegenwoordig helaas in fractieverband moet opereren, afwijzen. Een volksvertegenwoordiger is weliswaar onafhankelijk, maar hij is (per definitie) niet onpartijdig. Zijn onafhankelijkheid is gewaarborgd doordat in de Grondwet en de daarop gebaseerde wetgeving zijn staatsrechtelijke positie is geregeld. Daarmee zijn de grenzen gemarkeerd waarop hij en anderen acht hebben te slaan. Daarbinnen heeft hij echter vrijheid van handelen. Dat betekent dat we niet een enkel ideaalbeeld als uitgangspunt mogen nemen. Het is ook niet zo dat hij het binnen de hem toegemeten ruimte 'beter' doet naarmate hij zich zelfstandiger opstelt ten opzichte van zijn fractie of partij of van andere maatschappelijke verbanden waarin hij deelneemt.

Met behulp van deze uitgangspunten kunnen wenselijkheden geformuleerd worden, maar dat betekent nog niet dat er dan ook vanzelf een taak voor de wetgever ligt. Wij willen proberen om deze twee zaken scherp uit elkaar te houden. Ook de Venice Commission deed dat, waar zij aan de ene kant een Code of Good Practice publiceerde met tamelijk gedetailleerde adviezen aan politieke partijen, en aan de andere kant in haar Guidelines on legislation on political parties de regeringen van de lidstaten opriep zeer terughoudend te zijn met regelgeving op dit punt. ${ }^{20}$ De stap van normatieve oordelen naar wettelijke bepalingen is niet vanzelfsprekend. Bij het overwegen van die stap moet verder onder ogen worden gezien dat de wetgever niet tot het onmogelijke in staat is en dat wetgeving al gauw niet beoogde neveneffecten heeft die de remedie soms erger maken dan de kwaal die verholpen moest worden. Ons vierde uitgangspunt is daarom dat wetgeving achterwege behoort te blijven als er geen reële mogelijkheid bestaat om deze te handhaven of als ze het ermee beoogde doel niet naderbij zal brengen, dan wel tot niet aanvaardbare neveneffecten leidt.

Venice Commission 2009a en 2004. 


\section{$2 \quad$ Het staatsrecht en de politieke partijen}

\section{I Inleiding}

Politieke partijen zijn in het Nederlandse recht altijd beschouwd als vrij gevormde en vrij opererende maatschappelijke organisaties, waarop in beginsel slechts de regels van het privaatrecht van toepassing zijn. Toch heeft het staatsrecht grote invloed gehad op hun functioneren en is er in de staatsrechtelijke wereld zo nu en dan ook de nodige discussie geweest over het verschijnsel van de politieke partij en over de vraag of dit vermelding in de Grondwet en regeling bij wet behoeft. Daarover gaat deze paragraaf. ${ }^{21}$

\subsection{Voor 1917}

De grondwetswijziging van 1848 is in veel opzichten een keerpunt geweest in het Nederlandse staatsrecht. ${ }^{22}$ Eén van de belangrijkste veranderingen was de invoering van rechtstreekse verkiezingen voor de Tweede Kamer. Daartoe werd Nederland in enkelvoudige districten ingedeeld; in ieder district werd één Kamerlid verkozen. ${ }^{23}$ Het actief kiesrecht was overigens nog beperkt. Men moest een bepaald bedrag aan belastingen betalen om kiesgerechtigd te zijn, en vrouwen konden sowieso niet stemmen. In de Grondwet van I 848 werd tevens, zij het nogal angstvallig, ${ }^{24}$ de vrijheid van vereniging en vergadering verankerd. Een en ander bleek een belangrijke impuls voor de vorming van regionale kiesverenigingen die kandidaten voordroegen en stemadviezen gaven aan de kiesgerechtigden in hun district. Van landelijke coördinatie was daarbij aanvankelijk nog nauwelijks sprake, al werden daartoe al gauw wel de eerste pogingen ondernomen. ${ }^{25}$ Destijds is in de staatsrechtelijke literatuur met argusogen naar deze ontwikkeling gekeken. Illustrerend daarvoor is het volgende citaat van een vooraanstaand staatsrechtgeleerde uit die periode:

'In kiesverenigingen waarvan het publiek de leden niet kent, worden met meerderheid van stemmen candidaten gesteld, en dikwijls heeft de meerderheid van één enkele stem in een weinig talrijk bezochte vergadering over de candidatuur beslist. In advertenties worden de candidaten aanbevolen, uit naam van het bestuur der vereeniging. De kiezers stemmen dikwijls, omdat zij in de namen van het bestuur vertrouwen stellen, terwijl het vaak gebeurt, dat de aanbevolen kandidaat niet is de door de bestuurders gekozene, zodat de kiezers misleid worden.'

2I Voor een uitvoerig overzicht van de ontwikkeling van politieke partijen in Nederland: Koole 1995 .

22 Over de grondwetsherzieningen in de negentiende en het begin van de twintigste eeuw: Bannier 1936. Zie ook de website www.denederlandsegrondwet.nl.

23 Zie over de invoering van het districtenstelsel in 1848 en de daaropvolgende periode tot igI7: Loots 2004 .

24 Koekkoek 2000, p. 137. Het was een revolutiejaar in Europa.

25 Boogman 1978 , p. 72 e.v. 
Deze opvatting kan worden gezien als gemeengoed van die tijd. ${ }^{26}$ De kiesverenigingen, als aanzetten tot partijvorming, werden daarnaast gezien als een bedreiging voor de eenheid van de staat en de onafhankelijkheid van het parlement. ${ }^{27}$ Ondanks deze scepsis kwam het in het laatste kwart van de negentiende eeuw tot de ontwikkeling van meer hechte partijorganisaties. Maatschappelijke tegenstellingen en problemen vormden hiervoor een vruchtbare voedingsbodem: calvinisten en katholieken wensten gelijkstelling van het bijzonder en openbaar onderwijs (de zogeheten schoolstrijd); de katholieken streefden naar opheffing van hun achterstand in het overwegend protestants-christelijke Nederland; liberalen eisten herziening van het kiesrecht (de kiesrechtkwestie) en de opkomende arbeidersklasse begon zich op basis van de 'sociale kwestie' te organiseren.

Met de constituerende vergadering van de Antirevolutionaire Partij (ARP) ${ }^{28}$ op 3 april I879, was de eerste politieke partij in Nederland een feit. De socialisten, liberalen en katholieken zouden geleidelijk aan dit voorbeeld volgen. De charismatische voorman en oprichter van de antirevolutionaire partij, Abraham Kuyper, lichtte de oprichting ervan toe met de stelling dat een volksvertegenwoordiger van zijn partij de drager is van de (partij)beginselen, die de kiezers duidelijk maakt waar hij voor staat en die bij de kandidaatstelling een 'onbewimpelde beginselverklaring' aflegt. ${ }^{29}$ Intussen nam het aantal kiezers in Nederland toe doordat steeds meer burgers belasting betaalden en doordat in 1887 een beperkte wijziging van het kiesrecht had plaatsgevonden, waardoor ook andere tekenen van geschiktheid dan het betalen van belasting, zoals de genoten opleiding, recht gaven om te stemmen..$^{30} \mathrm{De}$ groei van het aantal kiezers was een extra stimulans voor de partijvorming. Binnen de andere politieke stromingen realiseerde men zich, evenals Kuyper, dat een sterkere organisatie noodzakelijk was geworden.

\subsection{De periode 1917-1945}

Naast I848 is ook 1917 een belangrijk jaar voor de staatsrechtelijke geschiedenis van Nederland. Bij de grondwetswijziging van 1917 werd niet alleen het algemeen kiesrecht ingevoerd, ${ }^{3 \mathrm{I}}$ ook het kiesstelsel ondervond een drastische wijziging: het districtenstelsel werd verruild voor een stelsel van evenredige vertegenwoordiging. ${ }^{32}$ De invoering van dit stelsel werd beargumenteerd met de stelling dat verkiezing op basis van evenredige vertegenwoordiging een parlement zou opleveren dat beter dan voorheen uitdrukking zou geven aan de onder de bevolking levende wensen

26 Elzinga I982, p. 24 e.v., waaraan ook het citaat is ontleend, J. de Bosch Kemper, Handleiding tot de kennis van het Nederlandse Staatsregt en Staatbestuur, Amsterdam I865, p. I77-I78.

27 Elzinga I982, p. 25.

28 De partij was calvinistisch en keerde zich tegen de 'geest' van de Franse revolutie, vgl. Van der Pot 2006, p. I50.

29 Kuyper 1879 , p. I30.

30 De grondwetsbepaling waarin dit zijn beslag kreeg, werd het 'caoutchouc-artikel' genoemd, omdat de wetgever er volgens de cynici alle kanten mee op kon; zie ook Nehmelman 2007, p. I35.

3I Aanvankelijk alleen voor mannen (voor vrouwen slechts het passief kiesrecht). In I9I9 werd ook het algemeen vrouwenkiesrecht in Nederland ingevoerd.

32 Uitvoerig over de grondwetsherziening van I9I7: Huart I925. 
en beginselen. Waarschijnlijk heeft ook meegespeeld dat evenredige vertegenwoordiging voordeliger is voor politieke stromingen met een over het gehele land verspreide aanhang. ${ }^{33}$ Sommigen verwachtten dat het nieuwe kiesstelsel het partijwezen zou tegengaan en dat het gemakkelijker zou worden voor niet-partijgebondenen om een parlementszetel te verwerven, maar de ervaring heeft geleerd dat van deze verwachting niet veel is terecht gekomen. ${ }^{34}$

Voor de partijvorming in Nederland is het nieuwe kiesstelsel van grote betekenis geweest. ${ }^{35}$ Onder het districtenstelsel, waarbij het absolute meerderheidssysteem werd gebruikt ('winner takes all'), waren de verkiezingen voor de vertegenwoordigende lichamen sterk op de persoon van de afgevaardigde gericht. Dit werd geheel anders met de invoering van het stelsel van evenredige vertegenwoordiging, dat een directe verhouding schept tussen het aantal stemmen dat op de kandidatenlijsten van politieke partijen wordt uitgebracht, en het aantal zetels dat aan de partijen wordt toebedeeld. De volksvertegenwoordiging werd daarmee een vrij nauwkeurige afspiegeling van de politieke krachtverhoudingen. De kiezer stemde vanaf nu primair op een politieke partij. Binnen de kandidatenlijst van een partij kon hij nog wel zijn voorkeur voor een bepaalde kandidaat aangeven, maar in de praktijk werden en worden de meeste stemmen op de lijsttrekker uitgebracht, waarmee de door de partij vastgestelde volgorde van de kandidaten bepalend werd voor de bezetting van de parlementszetels. Het partijwezen veranderde sterk door de invoering van het nieuwe kiesstelsel. Er kwamen landelijke verkiezingsprogramma's landelijke verkiezingscampagnes en landelijke lijsttrekkers en kandidatenlijsten. Dit bevorderde een centralisering en oligarchisering van de al onder het oude kiesstelsel ontstane partijorganisaties. Het betekende in feite een erkenning van de politieke partijen. ${ }^{36}$

Het nieuwe kiesstelsel veroorzaakte een sterke toename van het aantal partijen en fracties met als gevolg dat de regeringsvorming moeilijker werd en de besluitvorming moeizamer. Dit bleek een goede voedingsbodem voor de in het interbellum sterk toenemende kritiek op het fenomeen politieke partij, die overigens niet een typisch Nederlands verschijnsel was. In de jaren dertig werden het veelpartijensysteem en de gevolgen daarvan voor de politieke besluitvaardigheid ook onderwerp van politieke agitatie. De voorman van de Nederlandse fascisten, Mussert, ageerde op dit punt het felst: de machtsbegeerte van de politieke partijen zou naar zijn oordeel leiden 'tot de tyrannie van eenige cliques van partijleiders, aan welker dictatuur het geheele Volk en ook de Kroon onderworpen is'. ${ }^{37}$ Hoewel in de literatuur politieke partijen veelal werden gezien als een bestaansvoorwaarde voor de parlementaire democratie, vreesden sommigen ook dat door de toename van het aantal partijen en daarmee van het aantal partijtwisten de democratie uiteindelijk

33 Bovend'Eert \& Kummeling 2004, p. 68.

34 Elzinga I982, p. 3 I en 32 , noot 35.

35 Elzinga I982, p. 3 I.

36 Elzinga I982, p. 3 I.

37 N.S.B. (Nationaal-Socialistische Beweging) brochure, nr. 5, Utrecht, 1936, citaat uit: Elzinga I982, p. 33 . 
te gronde zou gaan. $3^{8}$ Toch waren er vanuit de staatsrechtbeoefening ook andere geluiden waarneembaar. Zo stelde Van der Pot, de oorspronkelijke auteur van het nog steeds gezaghebbende Handboek van het Nederlandse Staatsrecht, dat hij de geuite bezwaren op het evenredig kiesstelsel en het daaruit voortvloeiende disfunctioneren van de politieke partijen overtrokken vond. ${ }^{39}$ Onder degenen die zich in de jaren van de Duitse bezetting bezonnen op de vormgeving van het staatsbestel na de bevrijding en die daarover brochures, boeken of zelfs nieuwe Grondwetten schreven, waren er niet weinigen die de voorkeur gaven aan partijloze varianten waarin niet politieke verdeeldheid, maar juist de nationale eenheid tot uitgangspunt werd genomen. ${ }^{4^{\circ}} \mathrm{Zij}$ hebben op de naoorlogse ontwikkelingen echter geen invloed gehad. Direct na de bevrijding organiseerden de vooroorlogse politieke stromingen zich opnieuw in partijorganisaties, zij het soms onder een nieuwe naam of een iets veranderd profiel.

\section{$2.4 \quad$ Na 1945}

In de periode na 1945 is het kiesstelsel niet meer ingrijpend gewijzigd. Het bestaansrechtvan politieke partijen staat dan niet meer ter discussie. In politiek en staatsrecht rijst juist de vraag of de politieke partij niet een plaats diende te krijgen in het positieve recht. Een voorstel hiertoe werd in 1950 gedaan door een Staatscommissie die zich over de herziening van de Grondwet had gebogen, de Staatscommissie Van Schaik..$^{4 \mathrm{I}}$ De commissie stelde voor om een nieuw grondwetsartikel op te nemen, luidende:

'De wet kan, in het belang van een zuiver politieke wilsvorming, regels stellen omtrent politieke partijen.'

De Staatscommissie motiveerde het opnemen van een dergelijke bepaling met de belangrijke plaats die politieke partijen in het staatsbestel innemen en hun grote invloed op de staatkundige wilsvorming. Het trof de commissie als een anomalie, dat de Grondwet in geen enkele bepaling gewag maakt van deze partijen: 'Het beeld dat de Grondwet van onze staatsinrichting geeft is daardoor niet reëel', aldus de commissie. De voorgestelde bepaling zou niet alleen reliëf geven aan het partijwezen, maar zou tevens moeten bevorderen 'dat de gewone wetgever zich bezint op de vraag of het raadzaam is een wettelijke regeling betreffende de politieke partijen tot stand te brengen. ${ }^{42}$ De aanbeveling van de Staatscommissie Van Schaik had tot gevolg dat de regering een nieuwe Staatscommissie instelde die zich speciaal

\footnotetext{
38 Bijvoorbeeld Kranenburg I928, p. II5.

39 Van der Pot I940, p. 205.

40 Elzinga i982, p. 36. Simons ig66.

4I Staatscommissie ter herziening van de grondwet, I950. Van Schaik was ten tijde van het schrijven van het rapport vicepremier van het kabinet Drees/Van Schaik, hij was lid van de Katholieke Volkspartij (KVP). De benaming Staatscommissie wordt in Nederland soms gebruikt voor tijdelijke commissies, ingesteld door de regering en samengesteld uit prominent geachte leden.

Eindrapport Staatscommissie ter herziening van de grondwet, Den Haag I950, p. 55.
} 
zou moeten bezighouden met het kiesstelsel en met de wettelijke regeling der politieke partijen. Deze nieuwe Staatscommissie, naar haar voorzitters ook wel de Staatscommissie Teulings/Donner genoemd, adviseerde echter om af te zien van een wettelijke regeling van het partijwezen. Een wettelijke regeling van het partijverbod vond de commissie niet opportuun. Wettelijke eisen over de openbaarheid van financiën en over de controle op herkomst en besteding van partijgelden wees ze eveneens af, omdat van misstanden niet was gebleken en omdat controle niet effectief zou kunnen zijn. Regeling van de interne organisatie van politieke partijen achtte de commissie niet gewenst. De slotconclusie van de Staatscommissie luidde dientengevolge, dat

'alles samengenomen, althans voor het tegenwoordige, gegeven de toestand van het Nederlandse partijwezen, moet worden geoordeeld, dat voor enigerlei wettelijke regeling met betrekking tot het politieke partijwezen niet voldoende aanleiding bestaat. ${ }^{24}$

Telkens wanneer in latere jaren de vraag naar wetgeving weer eens opdook, werd deze uiteindelijk in gelijke zin beantwoord. ${ }^{44}$ In deze zelfde lijn adviseerde in 2009 een adviesorgaan van de Nederlandse regering, dat

'een grondwettelijke regeling (...) zou kunnen bijdragen aan - het beeld van 'verstatelijking' van politieke partijen en zou omgekeerd afbreuk kunnen doen aan - het beeld van - politieke partijen als particuliere organisaties (die weliswaar vitale functies vervullen voor het staatsbestel)'. ${ }^{45}$

De Staatscommissie Grondwet die in 2009 werd geïnstalleerd, heeft niet de opdracht gekregen om zich over dit onderwerp te buigen. Bijna was dat wel het geval geweest. Naar aanleiding van de discussies in de Tweede Kamer over de weerbaarheid van de democratie, die in paragraaf 5 nog ter sprake komen, en naar aanleiding van het advies dat de Raad van State uitbracht over de opdracht aan de Staatscommissie, had de regering het onderwerp in de conceptopdracht opgenomen. De Tweede Kamer vond een dergelijke vraag echter niet geschikt voor een Staatscommissie en verzocht de regering om op dit punt zelf het initiatief te nemen..$^{46}$ Daar is het tot nu toe bij gebleven.

43 Eindrapport Staatscommissie van advies inzake het kiesstelsel en wettelijke regeling der politieke partijen, Den Haag I958, vooral p. 29 e.v.

44 Zo kwam de Staatscommissie van advies inzake de Grondwet en de Kieswet (Staatscommissie Cals/Donner) in I97I in haar eindrapport tot eenzelfde conclusie als de Staatscommissie Teulings/Donner. Overigens is laatstgenoemde Donner de vader van eerstgenoemde Donner.

45 Raad voor het Openbaar Bestuur 2009, p. 52.

46 Kamerstukken II 2008-2009, 3I 570, nr. 6. 


\section{De verhouding tussen politieke partij en volksvertegenwoordiger}

\section{I Inleiding}

Een volksvertegenwoordiger pleegt weliswaar samen met anderen door een politieke partij te worden voorgedragen, maar hij dankt zijn benoeming aan de kiezers. Dit gegeven roept vanzelf de vraag op in hoeverre hij gedurende zijn zittingstermijn geheel zelfstandig is, of zich iets moet laten zeggen door de kiezers, de partij die hem heeft voorgedragen, of zijn partijgenoten die tegelijk met hem verkozen zijn. Daarover wordt verschillend gedacht en ook dat is een uiting van politiek pluralisme. Vanouds wordt de zelfstandigheid vooral door de liberalen benadrukt en vinden de socialistische partijen het vanzelfsprekend dat veel zaken collectief in de fractie worden beslist en dat de partij een belangrijke invloed heeft, ook in de periode tussen verkiezingen. Het staatsrecht stelt hieraan zekere grenzen, zoals we hierna zullen zien, maar laat ook ruimte voor verschillen in benadering.

Kwesties en thema's die hiermee verband houden, leveren periodiek stof voor discussie op in de politieke wereld of stof voor verbazing onder de burgerij. Een voorbeeld van dat laatste toonden de honderdveertig burgers die zich in 2006 op verzoek van de regering over de toekomst van het Nederlandse kiesstelsel beraadden, toen zij niet konden geloven dat een volksvertegenwoordiger die zijn fractie verlaat, gewoon in de Kamer kan blijven zitten. Hoewel hen daarover geen advies was gevraagd, namen zij in hun eindrapport hierover toch een standpunt in: ze beschouwden het als kiezersbedrog en deden een appel op politieke partijen en op de volksvertegenwoordigers om het niet zo ver te laten komen. ${ }^{47}$ Onder journalisten lijkt juist een wat romantisch ideaalbeeld van de onafhankelijke, eigenzinnige volksvertegenwoordiger de overhand te hebben. Sommige parlementariërs zien dit ook zo, maar voor de meesten lijkt 'fractiediscipline' geen thema..$^{8}$

Staatsrechtelijk zijn vooral die kwesties interessant waarbij men zich kan afvragen of er strijd bestaat met letter of geest van het samenstel van Grondwetsartikelen dat de positie van de volksvertegenwoordiger bepaalt. Uit de afgelopen tijd noemen wij drie voorbeelden. Het eerste betrof het al genoemde thema 'zetelroof': een volksvertegenwoordiger die partij en fractie verlaat maar zijn zetel niet opgeeft. Daarover is in $200 \mathrm{I}$ in de Tweede Kamer kortstondig gediscussieerd, nadat zich bijna een nogal buitenissig geval daarvan had voorgedaan. Het tweede betrof een verrassend verlopen verkiezing van de getrapt gekozen senaat in 2007 die ertoe leidde dat verschillende partijen druk uitoefenden op hun met voorkeurstemmen gekozen senatoren om hun zetel weer af te staan. Het derde voorbeeld betrof de zogenoemde 'partijafdrachtregeling' van de Socialistische Partij. Die partij laat haar volksvertegenwoordigers een overeenkomst tekenen, op grond waarvan hun volledige bezoldiging rechtstreeks in de partijkas wordt gestort. Daaruit ontvangen zij

47 Burgerforum 2006.

48 Thomassen \& Andeweg 2006. 
vervolgens een aanzienlijk lagere bijdrage om te voorzien in hun levensonderhoud. De regering heeft voorgesteld om dit bij wet te verbieden.

\subsection{De verhouding partij en volksvertegenwoordiger naar positief recht}

Het vierde artikel van de Nederlandse Grondwet geeft iedere Nederlander het recht om deel te nemen aan algemene verkiezingen en om te worden verkozen tot lid van de algemeen vertegenwoordigende organen, behoudens bij de wet gestelde beperkingen en uitzonderingen. Grondwet noch Kieswet reppen in dit verband van politieke partijen. Elke kiezer die bevoegd is deel te nemen aan een verkiezing, kan een kandidatenlijst indienen, mits de daarop voorkomende kandidaten hiermee instemmen en mits hij voldoende schriftelijke steunbetuigingen van andere kiezers kan overleggen (doorgaans dertig) en bovendien een waarborgsom betaalt. ${ }^{49}$ In de praktijk vergt een en ander dus de nodige voorbereiding en organisatie, al kan die in beginsel tamelijk elementair en tijdelijk zijn. Soms is ze dat ook, maar doorgaans pleegt de kandidaatstelling uit te gaan van al langer gevestigde politieke partijen of van partijen die nieuw zijn opgericht met het doel om een langer leven te leiden dan alleen de aankomende verkiezingsperiode. De wetgever heeft dit onder ogen gezien, waar hij zei dat 'het in de praktijk veelal een fictie is, dat het initiatief tot de indiening van een kandidatenlijst zou worden genomen door individuele kiezers die te zamen een lijst ondertekenen'. Toch achtte hij dit uitgangspunt van groot belang, omdat daardoor 'immers wordt gewaarborgd, dat de deelname aan de verkiezingen openstaat voor iedereen, ongeacht of hij al dan niet is aangesloten bij een politieke partij'..$^{\circ}$

Wie tot volksvertegenwoordiger wil worden gekozen, moet in de praktijk dus lid zijn van een bestaande politieke partij, of een nieuwe partij oprichten, en zien te bereiken dat hij door die partij kandidaat wordt gesteld. De manier waarop een partij de kandidatenlijst vaststelt, is een zaak die ze zelf mag bepalen. Het staatsrecht laat zich daarover niet uit. Is een kandidatenlijst eenmaal ingeleverd, dan is er in het staatsrecht geen enkele rol meer weggelegd voor degenen die daaraan, buiten de kandidaten zelf, een bijdrage hebben geleverd. De verkiezingsuitslag en de aanvaarding van hun benoeming door de gekozen kandidaten is maatgevend voor de bezetting van plaatsen in de volksvertegenwoordiging, waarbij de kiezers de volgorde van kandidatenlijsten nog kunnen doorbreken door het uitbrengen van voorkeurstemmen. Grondwet en Kieswet regelen de zittingsduur van de volksvertegenwoordiging. ${ }^{\text {II }}$ Aan het lidmaatschap komt daarbuiten slechts een einde door overlijden, door ontslagname, of indien onherroepelijk is komen vast te staan dat een lid een van de vereisten voor het lidmaatschap niet bezit of dat hij een met het lidmaatschap onverenigbare betrekking vervult en die niet wil opgeven..$^{2}$ Een

49 Kieswet, Hoofdstuk $\mathrm{H}$.

50 Kamerstukken II I987-I988, 20 264, nr. 3, blz. 25.

5 I Grondwet, artikelen 52 en I29, vierde lid. Kieswet, artikelen $\mathrm{Cr}_{\mathrm{I}}$ en $\mathrm{C}_{4}$.

52 Grondwet, artikelen 56 en 57 . Kieswet, artikel XI. 
volksvertegenwoordiger die uit zijn fractie stapt of eruit gezet wordt, of die zijn partijlidmaatschap opzegt of door zijn partij wordt geroyeerd, verliest zijn zetel dus niet. Bij het vervullen van opengevallen plaatsen is opnieuw de verkiezingsuitslag maatgevend..$^{53}$ Het grondwettelijk gebod om te stemmen 'zonder last' brengt tot uitdrukking dat de leden van de volksvertegenwoordiging op eigen titel stemmen en dit dus ook naar eigen overtuiging kunnen doen. ${ }^{54}$ Het Reglement van Orde van de Tweede Kamer deelt de Kamerleden in fracties in volgens de lijsten waarop zij gekozen zijn, tenzij betrokken Kamerleden zelf melden dat daarin verandering is gekomen, bijvoorbeeld doordat er een of meer leden zijn uitgetreden. 55 De indeling in fracties heeft in het reglement overigens alleen een functie voor de zitplaatstoedeling, de spreektijdverdeling en voor de op het reglement gebaseerde regeling voor financiële ondersteuning van de fracties..$^{6}$ Schadeloosstellingen en onkostenvergoedingen voor volksvertegenwoordigers komen uit de staatskas en zijn wettelijk geregeld. Datzelfde geldt voor wachtgelden en pensioenen voor volksvertegenwoordigers of hun nabestaanden. ${ }^{57}$

Met het voorgaande is de staatsrechtelijke verhouding tussen volksvertegenwoordiger en politieke partij geschetst. Het maakt allemaal een wat onthechte indruk, die niet als beschrijving van of als norm voor de werkelijke relatie tussen beide mag worden gezien. Een volksvertegenwoordiger is uit de aard der zaak immers ook deelnemer in het organisatorisch verband dat de politieke partij is, een verband met gedeelde politieke ideeën en een gedeelde geschiedenis. Hij is partijlid en lid van een fractie, bestaande uit zijn partijgenoten in de volksvertegenwoordiging, en hij staat dus ook in een sociaalpsychologische en deels een privaatrechtelijke verhouding tot zijn partijgenoten, zijn partij en de organen en leden daarvan. Daar zijn de relaties vaak hecht en de onderlinge afspraken kunnen tamelijk dwingend zijn. Dat is begrijpelijk en daar is ook niets op tegen. Integendeel: het komt zowel de politieke duidelijkheid als de besluitvaardigheid en de invloed van de volksvertegenwoordiging ten goede. Men kan het staatsrechtelijk bezien problematisch vinden, als het dusdanige vormen aanneemt dat in feite ongekozen partijleden of partijorganen (of nog anderen) vanuit de coulissen van de volksvertegenwoordiging aldaar de dienst zouden uitmaken of als de volksvertegenwoordiger de eigen verantwoordelijkheid voor zijn aandeel in de besluitvorming niet meer tot gelding kan brengen. De eerder geschetste regels zijn bedoeld om dat te voorkomen, doordat ze in geval van een conflict de gekozen volksvertegenwoordiger staatsrechtelijk bezien altijd het laatste woord geven: hij alleen bepaalt of hij zijn benoeming aanvaardt, voor zijn inkomen is hij van niemand afhankelijk, niemand kan hem naar huis sturen en elke

53 Artikelen WI-W6 Kieswet.

54 Grondwet artikel 67, derde lid.

55 Artikel II, Reglement van Orde van de Tweede Kamer der Staten-Generaal.

56 Reglement van Orde, respectievelijk artikel 5I, artikelen 43, 44a en 64, en artikel Io, derde lid, alsmede de op laatstgenoemde bepaling gebaseerde Regeling financiële ondersteuning fracties Tweede Kamer.

57 Artikel $6_{3}$ Grondwet, Wet schadeloosstelling leden Tweede Kamer, Wet vergoedingen leden Eerste Kamer en Algemene pensioenwet politieke ambtsdragers. 
door hem uitgebrachte stem is onaanvechtbaar. Zo heeft de Grondwetgever van 1983 het nadrukkelijk gewild en de grondwettelijke regels laten over de staatsrechtelijke kant van de zaak geen twijfel bestaan. Over de vraag of hiermee tevens grenzen zijn gesteld die doorwerken in de privaatrechtelijke verhoudingen tussen partij en volksvertegenwoordiger, bieden Grondwet noch grondwetsgeschiedenis duidelijkheid..$^{8}$

Privaatrechtelijk wordt de verhouding tussen partij en volksvertegenwoordiger, in zijn hoedanigheid van partijlid, beheerst door de statuten en reglementen van de partij, eventueel aangevuld met overeenkomsten die organen van de partij met (kandidaat)volksvertegenwoordigers hebben gesloten. Dergelijke overeenkomsten, bijvoorbeeld over afstand van de zetel als men de partij of de fractie verlaat, zijn in veel partijen gebruikelijk. Dat de autoriteiten op dergelijke reglementen en overeenkomsten geen acht hebben te slaan bij de toepassing van de staatsrechtelijke regels, spreekt voor zich en dat was in 1982 ook al eens bevestigd door de bestuursrechter. ${ }^{59}$ De vraag of partijen burgerrechtelijk wel nakoming kunnen vorderen van door hen aan (kandidaat)volksvertegenwoordigers opgelegde of met hen overeengekomen verplichtingen die de onafhankelijke positie van de volksvertegenwoordiger aantasten, is pas in I988 door de Hoge Raad beantwoord: de in het geding zijnde overeenkomst over afstand van zetels was nietig wegens strijd met het beginsel van het vrije mandaat en omdat de regeling van de gevallen dat een volksvertegenwoordiger moet aftreden, als uitputtend moet worden beschouwd. ${ }^{60}$ Lagere rechters oordelen sindsdien in gelijke zin: in rechte kan geen nakoming worden gevorderd. ${ }^{6 r}$

Over de vraag of de fracties verenigingen met burgerrechtelijke rechtspersoonlijkheid zijn, en ze dus in beginsel hun leden kunnen binden en met hen overeenkomsten kunnen sluiten, wordt in de staatsrechtelijke literatuur getwist, ${ }^{62}$ maar zelfs als dat zo zou zijn, dan zou voor de door de fractie genomen besluiten en voor de door haar gesloten overeenkomsten hetzelfde gelden als voor besluiten van en overeenkomsten met de partij zelf. ${ }^{63}$

\subsection{De praktijk}

\subsubsection{Zetelroof}

Het komt geregeld voor dat fracties na onenigheid een of meer leden verliezen die vervolgens op eigen houtje verder gaan. We zien dit het meest in nieuwe partijen en

58 De gedachtewisselingen blonken niet uit door helderheid, aldus Kortmann I987, p. 224, en Beers in Koekkoek 200o, p. 368.

59 Bepalingen van de Kieswet zijn van dwingend recht, zodat daaraan niet bij overeenkomst de kracht kan worden ontnomen, aldus de Afdeling rechtspraak van de Raad van State 6 september I982, AB I983, II4 (verkiezingsafspraak Beesel), m.nt. Eskes.

60 Hoge Raad I8 november I988, AB I989, I85 (verkiezingsafspraak Aruba) m.nt. FHvdB.

6 I Kantonrechter Groningen 3I januari 2002, NJ 2002, 238 (afdrachtregeling HoogezandSappemeer) en Voorzieningenrechter Haarlem 28 januari 2003, Gemeentestem 2003, 84 (zetelroof Haarlem) m.nt. Dölle.

62 Zie Bovend'Eert \& Kummeling 2004, p. III, en de daar vermelde literatuur.

63 Vgl. Elzinga \& Wisse I988, p. I83 en Dölle ig8I. 
in de vele lokale partijen die in gemeenteraden vertegenwoordigd zijn. Sinds ${ }^{2} 66_{5}$ liet de Tweede Kamer bijna dertig afsplitsingen zien, waarbij zo'n 45 Kamerleden betrokken waren. ${ }^{64}$ Slechts een enkeling vertrok daarna ook gelijk uit de Kamer. Nog minder komt het voor dat men overstapt naar een andere al bestaande fractie. Het overgrote deel ging zelfstandig verder. Bijna twintig nieuwe partijen kwamen hieruit voort, die op twee na allemaal meededen aan de daarop volgende verkiezingen, maar slechts vier keer heeft een dergelijke nieuwe partij ook zetels behaald. ${ }^{65}$ Een eenmansfractie kan ook ontstaan doordat een gekozene die in aanmerking komt voor vervulling van een tussentijds opengevallen zetel, inmiddels de partij heeft verlaten, maar zijn benoeming wel aanvaardt (dat is sinds 1946 één keer gebeurd) ${ }^{66}$, of al gelijk bij tussentijds aantreden niet tot de fractie wordt toegelaten (ook één keer gebeurd) ${ }^{67}$. Zelfs een Kamerlid dat uit zijn fractie en zijn partij stapt en gelijk ook de Kamer verlaat, kan nadien weer in aanmerking komen voor vervulling van een opengevallen zetel via de lijst van die partij. Dit is één keer bijna gebeurd, maar betrokkene bedacht zich op de valreep nadat er de nodige commotie over zijn plan was ontstaan. ${ }^{68}$

Deze laatste kwestie leidde in 200 r tot een discussie in zowel de Tweede Kamer als de senaat. In de Tweede Kamer werd de discussie aangezwengeld door twee prominente leden van grote fracties, de liberalen en de christendemocraten. Onder de kop 'Maak zetelroof onmogelijk' hadden zij in een artikel in een landelijk dagblad wijziging van de Kieswet op dit punt bepleit. ${ }^{69}$ In dat artikel vergeleken ze een Kamerfractie met een voetbalploeg, waarvan iedereen snapt dat het ongehoord zou zijn als een speler staande de wedstrijd naar het andere kamp zou overlopen, en waarin de trainer gedurende de wedstrijd ook gewoon spelers mag wisselen als hij dat nodig vindt. De minister van Binnenlandse Zaken wees erop dat de gronden voor beëindiging van het Kamerlidmaatschap limitatief in de Grondwet zijn geregeld. Hij vond het goed om over dit soort kwesties indringende discussies te voeren, maar wees wijziging van de Grondwet af. Wij moeten ons partijensysteem, dat een belangrijke rol speelt bij verkiezingen, niet zo dominant maken dat het erop neerkomt dat de partij alles uitmaakt, aldus de minister, en hij voegde daaraan toe dat de zetels in essentie van de kiezers zijn en niet van partijen. Naar zijn mening moest dat het uitgangspunt blijven..$^{0}$

64 Overzichten op de websites van het Documentatiecentrum Nederlandse Politieke Partijen (www. rug.nl/dnpp), en van de Tweede Kamer (www.tweedekamer.nl) en in Lucardie 2006.

65 Dat waren de Politieke Partij Radicalen (PPR) ontstaan in 1968, de Democratisch Socialisten '70 (DS'70) in I970, de Centrumdemocraten (CD) in I984 en de Partij voor de Vrijheid (PVV) in 2004.

66 Het Kamerlid Huyssen, dat in 1976 via de lijst van de Christelijk-Historische Unie in de Tweede Kamer kwam.

67 Het Kamerlid Van Oudenallen, dat in 2006 via de Lijst Pim Fortuyn in de Tweede Kamer kwam.

68 Jacques de Miliano, die in 200 I via de lijst van de christendemocraten opnieuw in de Kamer wilde komen, nadat hij de Kamer en de partij in 1998 had verlaten. Dit leidde tot krantenkoppen als 'IJdeltuit De Miliano pleegt zetelroof' (NRC Handelsblad ig januari 200I).

69 Ruud Luchtenveld en Maria van der Hoeven, Maak 'zetelroof' onmogelijk, in: Algemeen Dagblad, I7 oktober 2001 .

70 Handelingen II I8 oktober 200I, nr. I5, p. 843; zie ook Handelingen II 3I oktober 200I, nr. I7, p. II 25 (behandeling wetsvoorstel 27673 tot wijziging van de Kieswet). 


\subsubsection{Afspraken over de bezetting van zetels}

De Nederlandse senaat bestaat uit 75 leden en wordt getrapt gekozen door de provinciale volksvertegenwoordigers. Om alles in goede banen te leiden, plegen de politieke partijen deze verkiezingen nauwkeurig te orkestreren. Een element daarvan is, dat van de provinciale vertegenwoordigers wordt verwacht dat zij netjes op de lijsttrekker stemmen, zodat de door de partijorganen vastgestelde lijstvolgorde niet door hun voorkeurstemmen wordt verstoord. Via partijreglementen of te ondertekenen verklaringen wordt dit soms kracht bijgezet. Bij de verkiezingen van 2007 ging dit bij vijf partijen anders dan verwacht: doordat er toch voorkeurstemmen werden uitgebracht, werd in elk van die partijen een van de kandidaten louter op basis daarvan gekozen en had een hoger geplaatste kandidaat dus het nakijken. De getroffen partijen reageerden hier verschillend op. ${ }^{71}$ In twee partijen ontstond weliswaar enige commotie, maar werd verder geen actie ondernomen. Het partijcongres van de christendemocraten drong erop aan om alsnog te zorgen dat de gepasseerde kandidaat de laatste zetel zou bezetten. Daarop zegde de met voorkeurstemmen gekozen senator toe dat hij halverwege de zittingsperiode zijn plaats weer zou vrijmaken, hetgeen ook gebeurd is. Het partijbestuur van de Partij van de Arbeid deed een beroep op de met voorkeurstemmen gekozen senator om haar zetel af te staan en wees er daarbij op dat zij een verklaring had ondertekend dat zij het besluit van het partijcongres over de volgorde van de kandidatenlijst zou respecteren. Zij deed echter geen afstand van haar zetel en ze zit nog steeds voor deze partij in de senaat. Bestuur en partijraad van de Socialistische Partij reageerden in gelijke zin, maar ook in hun geval hield de met voorkeurstemmen gekozen senator voet bij stuk. Dat leidde er uiteindelijk toe dat hij werd geroyeerd. Hij vormt nu een eenmansfractie in de senaat.

Twee leden van de fractie van de Partij voor de Vrijheid in de Tweede Kamer, die zelf geen partijgenoten in de senaat hebben, vonden dat de partijen die druk hadden uitgeoefend op hun senatoren, hiermee het staatsrecht geweld hadden aangedaan. Zij noemden dit 'Oostblokachtige achterkamertjespraktijken'. ${ }^{72}$ De regering was van mening dat staatsrecht noch kiesrecht geschonden waren: de vijf met voorkeurstemmen gekozen senatoren konden, net als alle andere gekozen senatoren, aanspraak maken op een zetel in de senaat. Het stond hen ook vrij om hun benoeming niet te aanvaarden. $\mathrm{Zij}$ hadden dat alle vijf wel gedaan en meer viel er niet over te zeggen. ${ }^{73}$

\subsubsection{Afdracht van bezoldiging}

De meeste politieke partijen verwachten van hun volksvertegenwoordigers dat zij bovenop hun partijcontributie een flink bedrag doneren aan de partij. Sommige

7I Gegevens ontleend aan Lucardie \& Voerman 2008.

72 Vragen van de leden Wilders en De Roon (beiden PVV) aan de minister van Binnenlandse Zaken en Koninkrijksrelaties, 6 juni 2007, Aanhangsel Handelingen II 2006-2007, nr. Igor.

73 Inmiddels is wel een wetsvoorstel ingediend (Kamerstukken 32 I9I) en door de Tweede Kamer aangenomen, waarin onder andere de voorkeurdrempel bij senaatsverkiezingen wordt verhoogd om het moeilijker te maken de lijstvolgorde te doorbreken. 
partijen laten dit geheel aan de discretie van betrokkenen over en roepen slechts op om gul te geven. Andere hanteren centraal vastgestelde normbedragen voor een vrijwillige bijdrage. Verschillende partijen hebben een meer verplichtende regeling vastgelegd in besluiten van partijorganen waaraan de partijleden gebonden zijn en/ of laten kandidaat-volksvertegenwoordigers schriftelijk verklaren dat zij aan de vastgestelde afdrachtregeling zullen voldoen als zij verkozen worden. Deze laatste praktijk is in de literatuur omstreden, omdat ze volgens sommigen op gespannen voet staat met de zuiveringseed die volksvertegenwoordigers bij hun aantreden moeten afleggen. ${ }^{74}$ Een kantonrechter die eens over een statutaire afdrachtregeling te oordelen kreeg, oordeelde dat die regeling in strijd was met de openbare orde en daarom onverbindend, omdat ze de financiële onafhankelijkheid van de gemeentelijke volksvertegenwoordiger aantastte en zo diens vrije mandaat in gevaar bracht.

De Socialistische Partij gaat nog een stap verder. Prominent op haar website vermeldt deze partij:

'Alle volksvertegenwoordigers van de SP dragen hun vergoedingen af aan de partij, die daarvan weer activiteiten, campagnes en bijzondere initiatieven financiert. Zo maken we tevens duidelijk dat politici geen zakkenvullers hoeven te zijn.'

In ruil voor deze loyaliteit ontvangen de volksvertegenwoordigers van de partij een tegemoetkoming ter hoogte van een modaal inkomen. Een en ander pleegt te worden geregeld in een cessieovereenkomst tussen partijbestuur en volksvertegenwoordiger. Gevolg is dat de bezoldiging door de administratie van de volksvertegenwoordiging direct in de partijkas wordt gestort, zonder tussenkomst van de volksvertegenwoordigers. Enkele staatsrechtgeleerden hebben in publicaties gesteld dat de cessieovereenkomsten nietig zijn omdat zij van de volksvertegenwoordiger een werknemer in loondienst maken en aldus zijn zelfstandigheid aantasten. Zij riepen alle overheden op om niet hun medewerking hieraan te verlenen en de bezoldiging dus gewoon aan de volksvertegenwoordigers over te maken. ${ }^{75}$ Doordat jurisprudentie over deze casus ontbreekt, bracht dat die overheden in een lastig parket en zij gingen hier verschillend mee om. Zeven senatoren van vijf verschillende partijen verzochten de minister van Binnenlandse Zaken en Koninkrijksrelaties om de rechtstreekse stortingen in de partijkas onmiddellijk stop te (doen) zetten. ${ }^{76}$ De minister kondigde aan te zullen bezien hoe wettelijk geregeld kan worden dat bezoldigingen alleen nog aan de ambtsdragers zelf worden betaald. Een daartoe strekkend wetsvoorstel is in behandeling bij de Tweede Kamer. ${ }^{77}$

74 Die eed is geregeld in de Wet beëdiging ministers en leden Staten-Generaal, artikel 2, en bevat de volgende passage: 'Ik zweer (verklaar) dat ik, om tot lid van de Staten-Generaal te worden benoemd, rechtstreeks noch middellijk, onder welke naam of welk voorwendsel ook, enige gift of gunst heb gegeven of beloofd.'

75 Elzinga 2006 en Schutgens 2007a.

76 Vragen van de leden Rehwinkel (PvdA), De Vries (PvdA), Hermans (VVD), Schaap (VVD), Schuurman (Christenunie), Holdijk (SGP) en Engels (D66) van ro oktober 2007, Aanhangsel Handelingen I 2007-2008, nr. 3.

77 Kamerstukken 32220. 


\subsection{Moet de wetgeving aangevuld worden?}

Deze vraag diende zich hiervoor op twee geheel verschillende manieren aan. Enerzijds zagen we het pleidooi om partijen tegen 'zetelroof' te beschermen en hen of althans de fracties dus meer greep op hun volksvertegenwoordigers te geven. Anderzijds zagen we een voorstel om de greep van partijen op hun volksvertegenwoordigers juist te verminderen, namelijk op het punt van de partijafdrachten. Beide invalshoeken komen hieronder apart aan de orde.

De consternatie die in de fracties van de volksvertegenwoordiging zo nu en dan ontstaat over opvallende gevallen van 'zetelroof' is begrijpelijk. Hoewel er goede redenen kunnen bestaan voor een afsplitsing gepaard gaand met aanblijven, bijvoorbeeld bij een scheuring in de partij, kan daaraan in andere gevallen getwijfeld worden. Voor het vertrouwen in de politieke instituties en in de daarin benoemde personen is het in elk geval niet goed als volksvertegenwoordigers die nota bene tot dezelfde politieke richting behoren, al niet in staat blijken om hun onderlinge onenigheden op te lossen. De verbijsterde reacties van de leden van het 'Burgerforum Kiesstelsel' zijn hiervan een illustratie. Maar valt er iets tegen te doen, anders dan een moreel appel op betrokkenen en een zorgvuldige rekrutering door de politieke partijen zelf?

De liberale woordvoerder in het hiervoor vermelde Kamerdebat over dit onderwerp zag de door hem voorgestane wetswijziging als volgt voor zich:

'Iemand die om politieke redenen een fractie en ook het vertegenwoordigend lichaam verlaat, moet niet meer in dezelfde periode terug kunnen keren. (...) Daarnaast moet iemand die een fractie verlaat niet meer het recht hebben zich bij een andere fractie aan te sluiten of voor zichzelf in het vertegenwoordigend lichaam zitting te blijven nemen. ${ }^{78}$

Hij erkende daarbij ruiterlijk dat de kwestie van de partij die zelf het initiatief tot verwijdering wil nemen, veel ingewikkelder is.

Hiertegen pleit dat een regeling die aan het uittreden uit de fractie het verlies van de zetel verbindt, als praktisch gevolg zou hebben, dat minderheidsstandpunten binnen de fractie gemakkelijker kunnen worden genegeerd. Men kan daartegen inbrengen dat dit nu in feite ook al in hoge mate het geval is, maar twijfelende Kamerleden die vrij zijn hun eigen geweten te volgen en die daaraan desnoods de consequentie van vertrek kunnen verbinden, zal men proberen te overtuigen en dat leidt toch tot een ander type gedachtewisselingen dan als zij zonder meer overstemd kunnen worden. Juist de vrees voor 'afvallers' kan hier een gezonde invloed op de discussies hebben. Uiteindelijk komt dit de kwaliteit van de volksvertegenwoordiging ten goede. Het is bovendien de vraag of de voorgestelde regeling wel

78 Handelingen II 3I oktober 200I, nr. I7, p. III6. 
het beoogde gevolg zou kunnen hebben. Ze kan evengoed tot gevolg hebben dat dissidente fractieleden niet uit eigen beweging de fractie verlaten, maar wel afwijkend gaan stemmen en in de pers met afwijkende standpunten aan het woord komen, uiteindelijk de fractie geen andere keus biedend dan hen uit de fractie te verwijderen. Dat laatste leidt in het voorstel niet tot zetelverlies. Het aantal uittreders zou dus wel eens niet kunnen verminderen. Alleen het proces dat aan de uittreding voorafgaat zou onverkwikkelijker kunnen worden. Tenzij men er natuurlijk voor zou kiezen om ook aan de door de fractie opgelegde verwijdering toch maar zetelverlies te verbinden. Dat zou de fracties en daarmee de fractiemeerderheden pas echt oppermachtig maken, waarmee het grondwettelijke verbod van last in het geding zou komen. Het daarin neergelegde beginsel dat de volksvertegenwoordiger een eigen verantwoordelijkheid heeft voor zijn bijdrage aan de besluitvorming, verzet zich er niet tegen dat die bijdrage in wisselwerking met anderen wordt voorbereid en daardoor vaak verregaand wordt beïnvloed, maar het verzet zich wel tegen het zonder uitweg overdragen van de verantwoordelijkheid aan het collectief van de fractie en daarbij zou deze optie wel erg dicht in de buurt komen.

Een tweede bezwaar tegen het voorstel is, dat de wetgever vermoedelijk niet zou kunnen volstaan met uitsluitend voor het punt van desertie een regeling te ontwerpen. ${ }^{79}$ De huidige Grondwet regelt limitatief hoe het lidmaatschap van de volksvertegenwoordiging aanvangt en eindigt. In elk geval zouden dus de daarop betrekking hebbende bepalingen gewijzigd moeten worden. Een dergelijke grondwetswijziging vergt tevens de introductie van het begrip fractie in de Grondwet en er moet een verband gelegd worden tussen kandidatenlijsten en fracties ${ }^{80}$ Het werken met voorkeurstemmen is ineens misschien ook niet meer zo handig in een systeem dat geen desertie toestaat, omdat het een extra individuele legitimatie aan volksvertegenwoordigers kan geven. Zoals we zagen kan tevens het lastverbod ter discussie komen en zo vallen er nog wel wat onderwerpen te bedenken die in het verlengde hiervan waarschijnlijk (anders) geregeld of in elk geval opnieuw doordacht zouden moeten worden. Per saldo zou de uitkomst van een dergelijke operatie wel eens kunnen zijn, dat de invloed van de regering en van partijorganen op geestverwante fracties aanzienlijk zou worden versterkt. Die machtsverschuivingen zouden in geen verhouding meer staan tot de eenvoudige wens om incidentele gevallen van desertie uit de fracties tegen te gaan.

Ten slotte zou het ook internationaal gezien op zijn minst een aandacht trekkende verandering zijn. Blijkens een rapport van de Venice Commission zijn er maar weinig democratische stelsels waar de wetgeving gevolgen verbindt aan de desertie van volksvertegenwoordigers uit partij of fractie..$^{8 \mathrm{I}}$ In de landen die dit wel kennen, lijkt

\footnotetext{
79 Wat overigens al moeilijk genoeg is, omdat het verschil tussen ongeoorloofde desertie en reële gevallen van partijscheuring, die uiteraard zullen moeten worden toegelaten, niet anders dan door botte kunstgrepen (percentages afvallers e.d.) eenduidig valt te operationaliseren.

8o Merk op dat het nog steeds niet nodig zou zijn om politieke partijen in de Grondwet te vermelden.

8I Venice Commission 200gb.
} 
de situatie die aanleiding was om het te introduceren, bovendien onvergelijkbaar met de enkele incidenten die we in Nederland op dit punt hebben gehad. ${ }^{82}$ Het ging daar om zeer hoge percentages parlementariërs die van blok wisselden, vaak meerdere keren in één zittingsperiode en vaak tegen betaling of in ruil voor andere tegenprestaties of beloften. ${ }^{83}$ Het rapport noemt in dit verband binnen het gebied van de Raad van Europa alleen de Oekraïne en daarbuiten Nepal, Nigeria, Fiji, Bangladesh, Pakistan, India en Malawi. ${ }^{84}$ De Venice Commission ziet desertie dan ook vooral als een corruptieprobleem, maar is desondanks geen voorstander van dit type maatregelen:

'Even though the aim pursued by this kind of measures (i.e. preventing the 'sale' of mandates to the top payer) can be sympathetically contemplated, the basic constitutional principle which prohibits imperative mandate or any other form of politically depriving representatives of their mandates must prevail as a cornerstone of European democratic constitutionalism. ${ }^{85}$

Ze is nog beduidend negatiever over de mogelijkheid van het terugroepen van volksvertegenwoordigers door de partijorganen (recall):

'The complete dependence of the individual deputy on the party or electoral bloc is not compatible with the role a deputy has to play in a free parliamentary system. ${ }^{86}$

Voor het afzetten van corrupte volksvertegenwoordigers is een rechterlijke procedure het aangewezen middel.

Andersom rijst soms de vraag of volksvertegenwoordigers niet beter beschermd zouden moeten worden tegen hun politieke partij. Komt hun onafhankelijkheid niet in gevaar door allerlei interne partij- en fractieregels en door de verklaringen die ze voorafgaande aan hun kandidaatstelling ter tekening voorgelegd krijgen? Vooral in de jaren tachtig van de vorige eeuw zijn hieraan in de staatsrechtelijke literatuur de nodige kritische beschouwingen gewijd. ${ }^{87}$ In het licht van de hiervoor vermelde jurisprudentie past op deze vraag een genuanceerd antwoord.

82 De situatie op dit punt in Nederland lijkt overigens erg vergelijkbaar met die in de ons omringende landen. Zie daarover Lucardie 2006.

83 Het rapport van de Venice Commission vermeldt onder andere over India: 'In the time period from I967 to 19732,700 elected members crossed the floor. The biggest number did this towards governing parties. From the 2,700 members who crossed the floor in India during this period, 2I2 became ministers in the party that they crossed to.' En over de Oekraïne: 'According to some sources, between the 3 rd and 4 th legislatures (1998-2002 and 2002-2006), about 60\% of Ukrainian parliamentarians switched their party affiliation at least once. In some extreme cases, MPs changed their parliamentary group as much as Io times.'

84 Van der Hulst 2000 meldt op basis van een wereldwijde survey naast de genoemde landen ook nog: Kaapverdië, Jamaica, Namibië, Trinidad \& Tobago, Zambia, Zimbabwe en Ivoorkust.

85 De slotzin van Venice Commission 2009b.

86 Citaat uit hetzelfde rapport. Zie hierover ook Venice Commission 2007.

87 Elzinga I982, hoofdstuk 8, Elzinga \& Wisse I988, hoofdstuk 7, Dölle I98I. Daarin ook veel voorbeelden uit de praktijk. 
Voor het bewaren van de onafhankelijkheid van volksvertegenwoordigers, is het een belangrijk gegeven dat partij- of fractiereglementen en overeenkomsten met volksvertegenwoordigers, staatsrechtelijk geen effect hebben en ook bij de burgerlijke rechter niet afdwingbaar zijn gebleken voor zover ze op gespannen voet staan met de grondwettelijke en kiesrechtelijke bepalingen die de onafhankelijkheid waarborgen. Dat ontneemt de scherpte aan de vraagstelling, mits natuurlijk de betrokkenen zich dit zelf ook bewust zijn, maar dat lijkt over het algemeen wel zo te zijn. Het lijkt, zo bezien, dus wel mee te vallen. Maar dit maakt de geschetste praktijken natuurlijk alleen maar merkwaardiger. Juist als beide partijen weten dat een volksvertegenwoordiger zich niet mag en dus ook niet kan binden, krijgt het iets onfris om hem wel allerlei verklaringen te laten ondertekenen. Het zou beter zijn als partijen hun gebruiken slechts als een soort bijsluiter aan de kandidaten zouden meegeven. Voor de afdwingbaarheid maakt dat geen verschil: die is er in beide gevallen niet. Daarnaast zien we nog twee aspecten die een meer kritische benadering nodig maken.

Dat een belofte niet in rechte afdwingbaar is, wil niet altijd zeggen dat deze oorbaar is. De tekst van de door volksvertegenwoordigers bij hun aantreden af te leggen zuiveringseed spreekt eenvoudig van 'beloofd'. Er wordt verschillend gedacht over de vraag of het wel verenigbaar is met deze eed om een kandidaat-volksvertegenwoordiger voorafgaand aan zijn kandidaatstelling een verklaring te laten ondertekenen waarin hij belooft bij verkiezing een gedeelte van zijn bezoldiging te zullen afstaan. ${ }^{88}$ Met de letter van die eed staan dergelijke verklaringen inderdaad op gespannen voet. Dit is een extra reden om dit type beloften vooraf niet meer te vragen.

Een tweede punt is het feit dat soms derden gevolgen ondervinden van afspraken die zijn gemaakt tussen partij en (kandidaat)volksvertegenwoordigers. Zo valt het wel te begrijpen dat een partij de zorgvuldig vastgestelde lijstvolgorde liever niet te zeer verstoord ziet worden door voorkeurstemmen, maar ons kiesstelsel kent nu eenmaal de mogelijkheid om voorkeurstemmen uit te brengen. Het gewicht daarvan is de afgelopen tijd juist verhoogd om de kiezers meer invloed op de persoonskeuze te geven. Zeker als het om directe verkiezingen gaat, moet de kiezer die overweegt hiervan gebruik te maken, ervan kunnen uitgaan dat het ook betekenis heeft. Partijen die dit met het oog op de zorgvuldige samenstelling van hun fracties niet gewenst vinden, moeten maar voorstellen om het kiesstelsel op dit punt te veranderen.

Ook bij de hiervoor vermelde cessieovereenkomsten kunnen op dit punt vraagtekens worden gezet, al is ons bezwaar in dit geval niet van staatsrechtelijke aard. Dat het om hoge afdrachten gaat en dat het ingewikkelde rekenwerk dat er vermoedelijk aan te pas komt aan de partijadministratie wordt uitbesteed, dat zijn zaken die geheel

88 De wetgever vond in beginsel van wel, maar enkele staatsrechtelijke auteurs denken daar anders over: Kortmann I987, p. 214, Bovend'Eert \& Kummeling 2004, p.96-97, Leenknegt in Koekkoek 2000, p. 350, en (zeer uitgesproken) Schutgens 2007b; anders: Dragstra 2008, p. 315-320. 
passen in de opvattingen en de stijl van de Socialistische Partij. De volksvertegenwoordigers van die partij kunnen ook vast van het geld dat zij overhouden nog goed rondkomen, want er is niet gebleken dat zij bijbaantjes moeten nemen. Uit staatsrechtelijk oogpunt is het wel noodzakelijk dat de cessieoverenkomsten te allen tijde eenzijdig door de volksvertegenwoordiger kunnen worden opgezegd, maar dat is vermoedelijk ook het geval. Als de overeenkomst immers niet zelf al een dergelijk beding bevat, zal ze in de ogen van de rechter, in lijn met de vermelde jurisprudentie, nietig en dus niet afdwingbaar zijn.

De volksvertegenwoordiger kan er dus hoe dan ook op elk moment weer van af. Maar zo lang wij dat laatste niet heel zeker weten, delen de bezoldigingsadministraties van de volksvertegenwoordigingen in die onzekerheid en kunnen zij in situaties belanden waarin zij niet meer weten waartoe zij wel of niet rechtens verplicht zijn. Het zou beslist netter zijn om hen hierin niet te betrekken en dat kan natuurlijk ook best. Een cessieovereenkomst is voor het beoogde doel in het geheel niet nodig en, als de Socialistische Partij dit onder ogen ziet en haar praktijk anders vormgeeft, wetgeving evenmin.

Ter afronding nog dit: de vrijheid van handelen van de volksvertegenwoordiger binnen de hem toegemeten ruimte, geldt ook voor zijn fractie en zijn politieke partij. Wat we zien is, dat de onderlinge variatie in organisatiepatronen en organisatieculturen van politieke partijen ongeveer gelijk op gaat met de variatie in inhoudelijke standpunten, en het een staat hen in beginsel evenzeer vrij als het ander. Het levert doorgaans slechts aardige staaltjes partijfolklore op, eerder dan strijd met de grondregels van het staatsrecht, al verschillen de politieke partijen zelf daarover uit de aard der zaak van mening.

\section{$4 \quad$ De interne organisatie van politieke partijen}

\section{I Inleiding}

De Nederlandse wetgever heeft zich tot nu toe altijd op het standpunt gesteld, dat een politieke partij in beginsel zelf mag uitmaken wie zij als leden toelaat, welke rechtsvorm zij kiest en hoe ze de zaken verder intern organiseert. Net als de programmatische vrijheid werd dit gezien als een uitvloeisel van de vrijheid van vereniging, al zal hierna blijken dat praktische overwegingen de wetgever dit ook wel eens even hebben doen vergeten.

Twee onderwerpen waren de afgelopen tijd aanleiding voor pleidooien om deze terughoudendheid op te geven. Het eerste was de opkomst van enkele populistische partijen die nadrukkelijk geen leden wilden hebben, maar slechts sympathisanten, donateurs, kiezers en volksvertegenwoordigers. Dit riep de vraag op of een politieke partij die deel wil nemen aan democratische verkiezingen, zelf niet ook democratisch georganiseerd zou moeten zijn. Het tweede onderwerp betrof een kleine orthodox-protestantse partij die haar principiële standpunt dat vrouwen niet in bestuur of volksvertegenwoordiging thuishoren, binnen de eigen partij in praktijk brengt door hen uit te sluiten van plaatsing op de kandidatenlijsten. Nadat hierover 
door vrouwenorganisaties een hele serie gedingen tegen de Staat was aangespannen, heeft de Hoge Raad onlangs uitgesproken dat de Staat dit niet mag tolereren. De regering bezint zich nog op een reactie op dit arrest.

\subsection{Rechtsvorm en interne organisatie naar positief recht}

De wet eist niet een bepaalde rechtsvorm voor de oprichting en instandhouding van een politieke partij. Nochtans zijn de meeste politieke partijen, in elk geval de gevestigde partijen die landelijk opereren, rechtspersoonlijkheid bezittende verenigingen die zijn ingeschreven in het handelsregister. Voor een ledenorganisatie is de vereniging nu eenmaal de meest voor de hand liggende rechtsvorm en inschrijving in het handelsregister heeft het voordeel dat registergoederen kunnen worden verkregen, dat de vereniging erfgenaam kan zijn, en dat de bestuurders en ex-bestuurders niet naast de vereniging hoofdelijk aansprakelijk zijn voor schulden van de vereniging. ${ }^{89}$ Sinds de wijziging van de Kieswet van 1989 is deze rechtsvorm ook om andere redenen de meest aantrekkelijke geworden. Een politieke groepering die haar naam of een aanduiding daarvan wil laten registreren teneinde vermelding daarvan op de stembiljetten te bewerkstelligen, moet sindsdien een in het handelsregister ingeschreven vereniging zijn..$^{\circ}$ Deze eis is destijds uitsluitend ingevoerd om allerlei praktische verwikkelingen rond de naamsregistratie te verhelpen. Ze gaat verder dan voor dat doel nodig geweest zou zijn. ${ }^{91}$ Doordat andere wetten hierbij aanknoopten, is ze ook gaan gelden voor de toedeling van subsidie en van zendtijd aan politieke partijen. ${ }^{92}$ Wat de interne organisatie van de politieke partijen betreft, heeft de wetgever hiermee zijn principiële terughoudendheid in feite nogal terloops laten varen en is het burgerrechtelijk verenigingsrecht van dominante betekenis geworden, zoals de Raad van State in zijn advies over het wetsvoorstel tot subsidiëring van politieke partijen constateerde. ${ }^{93}$ Hoewel ook in de staatsrechtelijke literatuur hiervoor was gewaarschuwd, ${ }^{94}$ vonden de toenmalige regering en de parlementaire fracties dit destijds geen punt, omdat in de praktijk alle in het parlement vertegenwoordigde partijen aan het vereiste voldeden. Het minimum aantal leden dat in 1999 als voorwaarde voor subsidiëring werd ingevoerd (zie paragraaf 6) heeft deze keuze nog versterkt.

Het burgerrechtelijk verenigingsrecht heeft sinds 1976 een uitgebreide regeling in het Burgerlijk Wetboek. Sinds dat jaar hoeven verenigingen voor het verkrijgen van rechtspersoonlijkheid geen koninklijke goedkeuring meer te vragen. Wel regelt de wet sindsdien enkele hoofdlijnen van de organisatie van verenigingen, waarvan

89 Burgerlijk Wetboek, Boek 2, artikelen 26 tot en met 30.

go Kieswet, artikelen $\mathrm{G}_{1}, \mathrm{G}_{2}$ en $\mathrm{G}_{3}$.

9I Het was voldoende geweest om te eisen dat de groepering een geregistreerde vorm van rechtspersoonlijkheid heeft.

92 Artikel I, onderdeel b, van de Wet subsidiëring politieke partijen en artikel I.I van de Mediawet. Zie over subsidies en zendtijd ook paragraaf 6.

93 Kamerstukken II I997-I998, 25 704, A, p. I-2.

94 Zie Elzinga 1997, hoofdstuk 9, p. I2 e.v, en de daar aangehaalde literatuur. 
niet zonder meer bij de statuten kan worden afgeweken. Zo gaat de wet ervan uit dat elke vereniging als organen ten minste een algemene ledenvergadering en een bestuur kent. Als bevoegdheden van de algemene ledenvergadering noemt de wet benoeming, schorsing en ontslag van bestuurders, het goedkeuren van de financiële stukken, statutenwijziging en ontbinding, alsmede toelating tot het lidmaatschap en beslissing in beroep tegen ontzetting uit het lidmaatschap. ${ }^{95}$ De algemene ledenvergadering kan bestaan uit de leden of uit door de leden gekozen afgevaardigden. In het eerste geval heeft ieder lid toegang tot de vergadering en heeft ieder lid daar één stem. Bestaat de algemene vergadering uit afgevaardigden dan moet ieder lid aan hun verkiezing kunnen deelnemen. ${ }^{6}{ }^{6}$ Buiten eventueel in de statuten geregelde opzeggingsgronden, kan het lidmaatschap door de vereniging worden opgezegd als niet langer wordt voldaan aan de in de statuten genoemde vereisten van het lidmaatschap of als 'redelijkerwijs van de vereniging niet gevergd kan worden het lidmaatschap te laten voortduren'. Ontzetting (royement) kan alleen plaatsvinden als een lid in strijd met de statuten, reglementen of besluiten van de vereniging handelt, of de vereniging op onredelijke wijze benadeelt. Dit laatste is dus een disciplinaire maatregel. Er moet binnen de vereniging beroep tegen openstaan. ${ }^{97}$

Ook verenigingen die niet in het handelsregister zijn ingeschreven kunnen in het Nederlandse burgerlijk recht rechtspersoonlijkheid hebben. Men duidt ze over het algemeen aan als 'informele verenigingen'. Een enigszins georganiseerd samenwerkingsverband dat een herkenbare identiteit heeft en dat als zodanig aan het rechtsverkeer deelneemt (bijvoorbeeld een bankrekening heeft, een zaal huurt), is al snel zo'n informele vereniging en heeft dus rechtspersoonlijkheid, zij het dat de bestuurders naast de vereniging hoofdelijk aansprakelijk zijn en dat men als vereniging geen registergoederen kan verwerven noch kan erven. ${ }^{8}{ }^{8}$ Voor het overige zijn de bepalingen van het Burgerlijk Wetboek normaal op een dergelijke vereniging van toepassing en kan ze dus bijvoorbeeld ook ontbonden worden als haar werkzaamheid in strijd is met de openbare orde (zie paragraaf 5 ). Voor een politieke partij die haar naam vermeld wil zien op de stembiljetten en die aanspraak wil maken op subsidie en zendtijd, is deze figuur echter niet geschikt, zoals uit het voorgaande blijkt. Dat laatste geldt tevens voor andere rechtsfiguren dan de vereniging, zoals de stichting.

Daarnaast zijn politieke partijen in het maatschappelijk verkeer aan dezelfde regels gebonden als ieder ander. Voor zover politieke partijen personeel in dienst hebben, geldt voor hen in beginsel dus hetzelfde regime als voor andere werkgevers. Naast het arbeidsrecht en de arbeidsomstandighedenwetgeving, is bijvoorbeeld ook de wetgeving inzake gelijke behandeling, die discriminatie verbiedt, op hen

95 Asser-Maeijer 1997 , p. 208.

96 Burgerlijk Wetboek, boek 2, artikelen 38 en 39.

97 Burgerlijk Wetboek, boek 2, artikel 35.

98 Zie Asser-Maeijer I997, p. 240 e.v. De enige manier om in zo'n geval geen vereniging-rechtspersoon te worden, is het oprichten van een van de andere rechtspersonen die het Burgerlijk Wetboek kent, bijvoorbeeld de stichting. 
van toepassing in hun rol van werkgever. Op basis van die wetgeving mogen partijen eisen stellen die, gelet op hun doel, nodig zijn voor de vervulling van een functie, maar die eisen mogen niet leiden tot onderscheid op grond van het enkele feit van ras, geslacht, nationaliteit, hetero- of homoseksuele gerichtheid of burgerlijke staat. ${ }^{99}$ Onderscheid naar politieke gezindheid ligt bij veel partijfuncties uit de aard der zaak juist voor de hand, evenals onderscheid naar godsdienst bij partijen op confessionele grondslag. Op die beide punten hebben politieke organisaties in de wet daarom meer ruimte gekregen dan gewone werkgevers. ${ }^{100}$ Het interne verenigingsrecht wordt niet bestreken door de wetgeving inzake gelijke behandeling. De Commissie Gelijke Behandeling, die op naleving van deze wetgeving toeziet, laat zich dan ook in beginsel niet uit over zaken als de in de statuten neergelegde eisen voor lidmaatschap, de statutaire stemrechtregelingen of de toelating tot het bestuurslidmaatschap van de vereniging. ${ }^{\text {Ior }}$ Ook op de kandidaatstelling door politieke partijen ziet de gelijkebehandelingswetgeving niet. ${ }^{\mathrm{102}}$

\subsection{De praktijk}

\subsubsection{Interne democratie}

Tot voor kort kenden de meeste Nederlandse politieke partijen structuren en procedures die ertoe leidden dat de invloed van de leden hoofdzakelijk tot gelding kwam via de algemene ledenvergadering, meestal 'partijcongres' genoemd. Dat congres bestond doorgaans uit afgevaardigden die in de partijafdelingen waren gekozen. Alleen bij de in I966 opgerichte partij D66 kunnen vanouds alle leden de bijeenkomsten van het partijcongres bezoeken en daar ook meestemmen. Binnen de partijen speelt de partijtop (fractie en partijbestuur) doorgaans een overheersende rol, die sinds de jaren zeventig van de vorige eeuw bovendien nog aanzienlijk is versterkt. De congressen hebben zich steeds meer ontwikkeld tot fora voor verantwoording en controle achteraf. ${ }^{103}$

In reactie op verkiezingsnederlagen zijn bijna alle gevestigde partijen de afgelopen jaren gaan experimenteren met mogelijkheden voor rechtstreekse deelname aan de besluitvorming door de partijleden: soms door, net als D66, alle leden toe te staan het partijcongres bij te wonen, soms door partijreferenda over bepaalde onderwerpen uit te schrijven en soms door rechtstreekse verkiezingen van lijsttrekker en van partijvoorzitter. ${ }^{104}$ Vooral de verkiezingen van personen, per internet of brief, lieten een redelijk hoge opkomst zien, soms meer dan vijftig procent van het

99 Algemene wet gelijke behandeling, artikel 5, tweede lid, onderdeel b.

Ioo Kamerstukken II I990-I99I, 22 oI4, nr. 3, p. I7.

IOI Daarover o.a. Hertogh \& Zoontjens 2006, p. I8I e.v.

I02 Commissie Gelijke Behandeling 2I december 200I, oordeel 200I-I50. Zie hierover ook de antwoorden op de vragen van het Tweede-Kamerlid Van der Ham (D66) over het bericht dat de ChristenUnie een kandidaat van de kieslijst weert vanwege een homoseksuele relatie. Aanhangsel Handelingen II 2009-2010, nr. 1069.

I03 Koole r992.

I04 Daarover Voerman 2005, waaraan hier het nodige is ontleend. 
aantal partijleden. Op de ledencongressen is echter zelden meer dan vijf procent van de leden aanwezig, al zijn er flinke uitschieters naar boven als bijvoorbeeld het al of niet (verder) deelnemen aan een regeringscoalitie aan de orde is. In de politicologische literatuur wordt deze ontwikkeling met gemengde gevoelens gadegeslagen. Enerzijds wordt het toegejuicht dat partijen proberen ook de gewone leden actiever bij de besluitvorming te betrekken. Maar aan de andere kant worden ook risico's gesignaleerd die aan de nieuwe plebiscitaire methoden verbonden zijn: ze kunnen de macht van het partijbestuur juist versterken ten koste van het middenkader en volgens sommige auteurs zijn ze daar ook voor bedoeld, de partij wordt kwetsbaarder voor acties door interne minderheden, een gekozen lijsttrekker zal zich minder aan het partijprogramma gelegen laten liggen, enzovoort. Voor een definitief oordeel vinden de meeste auteurs het nog te vroeg. ${ }^{105}$

De vermelde ontwikkeling is geheel voorbij gegaan aan de nog jonge populistische Partij voor de Vrijheid (PVV), opgericht door Geert Wilders, nadat hij in 2004 uit de liberale fractie in de Tweede Kamer was gestapt wegens onenigheid over zowel de inhoud van zijn opvattingen als de nogal eigengereide stijl van zijn optreden. Hij behield zijn zetel in het parlement. De partij, toen nog 'Groep Wilders' genoemd, begon zijn bestaan dus gelijk met één volksvertegenwoordiger. Nog in 2004 richtte Wilders een stichting op, waarvan hijzelf het enige bestuurslid is, om geld voor zijn campagne in te zamelen. Vanwege het eerder vermelde vereiste van de Kieswet, richtte hij daarnaast in 2005 een vereniging op, zodat er voortaan een aanduiding van zijn partij boven de kandidatenlijst op de stembiljetten mocht worden geplaatst. Omdat voor het oprichten van een vereniging twee oprichters nodig zijn en ten minste één lid, werd ze opgericht door Wilders zelf én door de eerdergenoemde stichting waarvan hij het enige bestuurslid is. De vereniging had en heeft nog steeds maar één lid, tevens enig bestuurder, namelijk Wilders. ${ }^{106}$ Bij de verkiezingen in 2006 kwam de partij met negen zetels in het parlement. Sinds de verkiezingen van 2010 heeft ze 24 zetels. ${ }^{107}$ Op dit moment ${ }^{108}$ is de fractie van de PVV betrokken bij de formatie van een nieuw kabinet, al zal de partij daarvoor zelf waarschijnlijk geen ministers leveren.

Op de websites van de PVV wordt niets over het lidmaatschap van de partij gezegd. Wel wordt talent geworven om voor de partij kandidaat te staan bij de verkiezingen van de provinciale volksvertegenwoordigingen en van de senaat in 20II. Ook donateurs, vrijwilligers en stagiairs kan de partij goed gebruiken. Staatssubsidie krijgt de partij niet, omdat ze daarvoor niet voldoende leden heeft (zie daarover paragraaf. 6). Wel komt de fractie in aanmerking voor de financiering van fractieondersteuning in het parlement.

I05 Zie Voerman 2005 en de daarin besproken literatuur, en ook Koole 2006.

Io6 Gegevens ontleend aan Raad voor het openbaar bestuur 2009, p. 24 en aan Joep Dohmen, 'Alleen Wilders lid PVV', NRC Handelsblad 2I april 2007.

I07 Daarnaast sinds 2009 vier afgevaardigden in het Europese parlement.

Io8 3r augustus 2010. 
Het ledenloze karakter van de PVV is niet uniek. Enkele verwante populistische partijen, die echter niet voldoende stemmen hebben gehaald om vertegenwoordigd te worden in het parlement, hadden een vergelijkbare opzet. ${ }^{109}$ Naast de karakters van de oprichters en hun afkeer van de gevestigde politiek en van het vooruitzicht van langdurige vergaderingen met moties en amendementen uit alle uithoeken van het land, lijkt daarbij ook het voorbeeld te hebben meegespeeld van de verwante Lijst Pim Fortuyn (LPF), wier korte bestaan (2002-2008) een aaneenrijging was van onderlinge ruzies, afsplitsingen en rechtsgedingen. In de motivering die Wilders zelf voor het ledenloze karakter van zijn partij geeft, komen al deze motieven samen:

'Ik heb mijn lesje geleerd van de LPF. Ik weet hoe het fout kan gaan als je een partij te snel openstelt voor leden. Als de mensen met de verkeerde agenda of portemonnee een partij kapen. (...) Dus heeft de PVV geen leden en liet ze dit jaar een flinke subsidie aan zich voorbijgaan. (...) Trouwens, als wij morgen de partij open zouden stellen voor leden, hadden we er morgenavond al duizend. Maar hoe zorg je dat die eerste groep een beetje te vertrouwen is? Je móet iets organiseren, maar je moet het zorgvuldig doen. De vraag is bovendien in welke vorm. Moet dat geïnstitutionaliseerd, met allemaal lokale partijbaronnen? Ik krijg nu nog blindedarmontsteking als ik denk aan hoe dat bij de VVD ging. Om je te kandideren moest je het hele land door, alle voorzitters van de Kamercentrales af en tegen de grootste idioot zeggen dat hij geniaal was.' ${ }^{\text {II }}$

Het nieuwe fenomeen van de ledenloze partijen heeft vooral in de media sterk de aandacht getrokken. De journalistieke reacties in de algemene kranten en tijdschriften kenmerkten zich over het algemeen door verbazing en soms hilariteit. Enkele sociale wetenschappers spraken zich uitgesproken kritisch uit. De politicoloog Koole is van mening dat ledenpartijen beter zijn voor de democratie dan partijen zonder leden, omdat een partij zonder interne democratie ongeloofwaardig is en bovendien geen leerschool biedt voor komende politici. ${ }^{11 I}$ De socioloog Van Doorn zag er een expliciete keuze in voor een autoritair politiek systeem, en achtte het moeilijk verenigbaar met wat in een democratie het meest wezenlijke wordt geacht: georganiseerde inspraak en tegenspraak op alle vertegenwoordigende niveaus. De bijval ervoor bevestigde hem in zijn opvatting dat het met de democratie in ons land niet goed gesteld is. ${ }^{\text {I2 }}$ Zijn collega Zijderveld, tot voor kort lid en 'ideoloog' van de christendemocratische partij, viel hem daarin bij. Dat sympathisanten geen lid kunnen worden en geen invloed kunnen uitoefenen binnen de partij, vond hij een gevaarlijke ontwikkeling die hem deed denken aan de opkomst van de Nationaal-Socialistische Beweging (NSB) in de jaren dertig van de vorige eeuw. ${ }^{\mathrm{II} 3}$ Enkele liberale en christendemocratische oud-politici vermeldden de ondemocratische organisatie van de PVV als een van de redenen waarom zij vonden dat hun partij geen coalitie met de PVV

Io9 Zie Raad voor het openbaar bestuur 2009, p. 25.

IIO Geciteerd in: Koen Haegens, “Ik wil echt niet de Kim Il Sung uithangen”. Hoe nieuw wordt Wilders' nieuwe beweging?’ in De Groene Amsterdammer, 2 mei 2007.

III Koole 2007. Zie ook Koole 200I.

II2 Van Doorn 2009, p. 516.

II3 De Telegraaf, 27 april 2009, 'PVV net NSB'. 
zou moeten vormen. ${ }^{114}$ Opwinding over het ledenloze karakter van de PVV komen we verder vooral tegen in de vaak zeer vele reacties op internetpublicaties over deze partij en in allerlei weblogs. Ten minste een van de vele bloggende commentatoren heeft zijn opinie tevens in een landelijk dagblad geplaatst weten te krijgen. Hij zag er voldoende reden in om te concluderen dat het nu tijd is geworden voor een Wet op de politieke partijen. ${ }^{\text {II }}$

\subsubsection{Gelijke behandeling}

Onder de 150 Tweede-Kamerleden zijn op dit moment 62 vrouwen. Dat is iets meer dan veertig procent. Dat percentage kan nog iets stijgen als een kabinet is geformeerd, omdat enkele prominente Kamerleden dan minister of staatssecretaris zullen worden en hun plekken zullen worden opgevuld door lager geplaatsten op de kandidatenlijsten. Maar het ooit geformuleerde streven om in 2010 een percentage van vijftig procent te halen, welk doel later al eens verlaagd was naar 45 procent, ${ }^{116}$ zal zeker niet bereikt worden. Toch is het resultaat al mooi als je het vergelijkt met zo'n vijftig jaar geleden toen gehuwde vrouwen in Nederland nog maar net juridisch handelingsbekwaam waren geworden en voor ambtenaressen nog maar net het ontslag van rechtswege zodra zij in het huwelijk traden, was afgeschaft. ${ }^{\text {II7 }}$

Bijna alle politieke partijen leverden een bijdrage aan deze toename. Eén partij deed dat om principiële redenen niet: de Staatkundig Gereformeerde Partij (SGP). Dit is een orthodox-protestantse partij met een kleine maar stabiele aanhang, opgericht in I9I8 uit onvrede met de ontwikkelingen in de toen bestaande protestantse partijen, onder andere wegens hun weigering om het vrouwenkiesrecht te blokkeren. ${ }^{\text {II8 }}$ In de Tweede Kamer heeft de partij steevast twee of drie zetels. Op veel terreinen heeft de partij standpunten die buiten de eigen kring niet goed begrepen worden, laat staan enige weerklank vinden. Wat het kiesrecht betreft, is de SGP de enige partij die van oordeel is dat dit niet zou moeten worden toegekend aan individuen, maar aan verbanden zoals het gezin. ${ }^{\text {II }}$ Het algemeen kiesrecht zoals wij dat kennen, gaat in de ogen van de SGP ten diepste uit van individualisering, die de organische opbouw van de samenleving miskent. Dit uitgangspunt en de opvattingen van de partij over vrouwenemancipatie ${ }^{120}$ werken door in de positie van vrouwen in de partij. Tot voor kort konden vrouwen slechts buitengewoon lid van de partij

II4 Zie onder andere 'Voorhoeve kritisch over samenwerking met PVV' in De Telegraaf, I5 augustus 20Io, en 'Aantjes: kabinet met PVV is slechtste optie' in Nederlands Dagblad, zo juni 2010.

II5 Jan Dirk Snel, 'Het is tijd voor een wet op de politieke partijen', in NRC Handelsblad, I2 mei 20 Io.

II6 Meerjarenbeleidsplan emancipatie 2006-20I0, Kamerstukken II 2005-2006, 30 420, nr. 2, p. 37.

II7 Namelijk sinds respectievelijk I januari en 24 december 1957.

II8 Daarover Dölle 2006.

II Artikel 8 van het Program van beginselen van de partij luidt: 'De overheid regeert bij de gratie Gods en dient dit ondermeer tot uitdrukking te brengen in het ambtsgebed. Zij ontleent dus haar gezag niet en kan dat ook nimmer ontlenen aan het volk. Haar ambt oefent de overheid evenwel uit onder medewerking van het volk. Die medewerking wordt verkregen door het kiesrecht toe te kennen. De overheid behoort een organisch kiesrecht te bevorderen dat rekening houdt met het gezin als cel van de samenleving.'

I20 In artikel 7 van het Program van beginselen staat onder meer: 'Maatregelen ter erkenning van de gelijkwaardigheid van mannen en vrouwen worden positief beoordeeld. Elk emancipatiestreven 
worden en nog steeds stelt de SGP om principiële redenen geen vrouwen kandidaat bij verkiezingen.

Deze situatie bestond dus al op het moment dat Nederland in I99I partij werd bij het VN-Vrouwenverdrag, ${ }^{\mathrm{I2I}}$ waarvan artikel 7 de Staat verplicht 'alle passende maatregelen' te nemen 'om discriminatie van vrouwen in het politieke en openbare leven van het land uit te bannen'. De Staat verplichtte zich daarbij in het bijzonder om vrouwen onder meer het recht te verzekeren om op gelijke voet met mannen verkiesbaar te zijn in alle openbare lichamen en deel te nemen aan verenigingen op het gebied van het politieke leven. Tijdens de plenaire behandeling van de goedkeuringswet voor het verdrag is de betekenis van de laatstgenoemde verplichting voor de positie van politieke partijen aan de orde geweest. De regering stelde zich op het standpunt dat de betekenis van die bepaling moet worden gezien in samenhang met bepalingen in andere verdragen over onder meer de vrijheid van vereniging en vergadering. Om die reden achtte zij een grote terughoudendheid geboden bij het stellen van wettelijke regels voor politieke partijen omdat de aan deze organisaties toekomende democratische rechten en vrijheden behoren tot de grondslagen van onze rechtsorde. Krachtens andere verdragen is een dergelijk ingrijpen slechts onder zeer strikte voorwaarden aanvaardbaar en die voorwaarden waren op dat moment niet aanwezig. Een voorbehoud bij het verdrag op dit punt, leek de regering niet nodig, nu er immers ruimte voor afweging was. ${ }^{\text {I22 }}$ Dat de rechter een rechtstreeks beroep op de bepaling op termijn ooit eens zou honoreren, achtte de regering niet uitgesloten, maar zij leek zich daar weinig zorgen over te maken. En waarom zou zij ook? Iedereen wist dat deze in abstracte termen gevoerde discussie betrekking had op de SGP en van de vrouwen uit de SGP-achterban zou uit de aard der zaak niet snel een dergelijk beroep op de rechter verwacht kunnen worden. Mocht het ooit zo ver komen, dan was de tijd daar misschien ook wel rijp voor.

Vanaf de inwerkingtreding voor Nederland van het Vrouwenverdrag is de situatie bij de SGP in vaak scherpe bewoordingen aan de orde gesteld in de verslagen en rapportages over de uitvoering van het verdrag. De eerste nationale rapportage in I997 wees in dat verband al gelijk op de mogelijkheden van stopzetting van subsidie en van het partijverbod. ${ }^{23} \mathrm{Na}$ vele latere rapportages, ook van de kant van de VN zelf (Committee on the Elimination of Discrimination against Women), en vele acties en gedingen tegen zowel de SGP als de Nederlandse Staat, heeft dit begin 2010, mede dankzij de in 1994 geïntroduceerde mogelijkheid van de collectiefbelangactie in het burgerlijk recht, uiteindelijk geleid tot een uitspraak van de Hoge Raad,

dat de van God gegeven roeping en plaats van mannen en vrouwen miskent, is revolutionair en moet krachtig worden bestreden.'

I2I Verdrag inzake de uitbanning van alle vormen van discriminatie van vrouwen, New York, 6 oktober i999.

I22 Kamerstukken II I984-I985, I8950 (R I28I), C, p. I9; I986-I987, I8950 (R I28I), nr. 6, p. 30; I988I989, I8 950 (R I28I), nr. 9, p. I4; en Kamerstukken I I990-I99I, I8 950 (R I28I), nr. 72, p. 3. Eenzelfde conclusie trok de regering bij de totstandkoming van de Algemene wet gelijke behandeling en van de Wet subsidiëring politieke partijen.

I23 Groenman I997, paragraaf 4.2.4. 
uitgelokt door een groot aantal belangengroepen uit de vrouwenbeweging en uit de grondrechtenhoek. De Hoge Raad was van oordeel (dat het Hof tot de conclusie had kunnen komen) dat de wijze waarop de SGP bij de kandidaatstelling voor de algemeen vertegenwoordigende organen haar opvatting in praktijk brengt, in het licht van het Vrouwenverdrag niet kan worden aanvaard, dat de Staat gehouden is om maatregelen te nemen die er daadwerkelijk toe leiden dat de SGP het passief kiesrecht aan vrouwen toekent en dat de Staat daarbij een maatregel moet inzetten die effectief is en tegelijkertijd de minste inbreuk maakt op de grondrechten van de (leden van de) SGP. ${ }^{124}$ Op de aard van die maatregelen bezint de regering zich nog.

\subsection{Is ingrijpen door de wetgever gewenst?}

Degenen die zich zodanig aan de geschetste praktijken ergeren dat zij gelijk maar een partijverbod in overweging geven, ${ }^{\mathrm{I} 25}$ komen niet toe aan de vraag of die praktijken aanleiding moeten zijn voor de wetgever om in te grijpen. Zoals uit paragraaf 5 kan worden afgeleid, is zo'n verbod echter volstrekt niet aan de orde. Wij beperken ons daarom hier verder tot de vraag naar de wenselijkheid van ingrijpen door de wetgever.

\subsubsection{Ledenloze partijen en interne democratie}

In de literatuur wordt aangenomen dat het burgerrechtelijk verenigingsrecht garant staat voor een minimum aan interne democratie binnen de geregistreerde politieke partijen. Een enkele auteur spreekt zelfs van 'tamelijk stringente eisen aan de interne democratie', ${ }^{126}$ maar dat geldt uit de aard der zaak alleen voor klassieke partijen met leden en afdelingen en niet voor een ledenloze partij als de PVV. Toch heeft die partij zich zo te zien netjes gehouden aan de bepalingen van het Burgerlijk Wetboek. De crux zit hem in het al of niet toelaten van extra leden en dat is iets wat een vereniging zelf mag bepalen uit hoofde van de verenigingsvrijheid.

Hoe erg moeten we dit eigenlijk vinden en is het reden voor de wetgever om in te grijpen? Om te beginnen mogen we het ontbreken van interne democratie niet gelijk stellen met het hebben van kwalijke opvattingen over de democratie in staatsverband. Een partij met een ondemocratisch programma zal intern doorgaans ook niet democratisch georganiseerd zijn, maar het omgekeerde hoeft niet het geval te zijn. Verder is het een gegeven dat een nieuwe partij die enig succes heeft, per definitie een charismatisch leiderschap heeft. Los van de formele structuur en de vergadergebruiken zal een dergelijke partij daardoor intern nooit erg democratisch func-

I24 Hoge Raad 9 april 20Io, NJ 20I0, 388 (m.nt. Alkema), AB 20Io, I9o (m.nt. Van Ommeren), JB 20I0, II5 (m.nt. Schutgens en Sillen), NTM/NJCM-Bulletin, jrg. 35, nr. 5, p. 485-500 (m.nt. Woltjer en Nehmelman).

I25 Zie in de SGP-kwestie: Groenman I997. Daarnaast, vermeld in Dölle 2006: H.U. Jessurun d'Oliviera in Trouw, 8 januari 2002. Ook Barkhuysen lijkt wel te voelen voor een partijverbod. Zie Barkhuysen 2004.

I26 Koole I992, p. 4II. Zie (uitgebreid) ook Buys \& Groeneveld-Louwerse I996, p. I03-II2. 
tioneren. ${ }^{127}$ Het is voorspelbaar dat dit na enige tijd weer zal veranderen en er zijn inmiddels ook al signalen dat het onderwerp binnen de PVV-gelederen aan de orde wordt gesteld. Een charismatische partij die zich niet breder organiseert en die de organisatie niet tijdig consolideert, wat altijd gepaard gaat met het delen van zeggenschap, overleeft het vertrek van zijn leider niet. Alleen al daarom zal de interne druk om hier iets aan te doen, met de tijd vanzelf toenemen. Tenslotte is het begrijpelijk en zelfs wel verstandig als een succesvolle nieuwe partij zich vooreerst op het werven van kandidaten en kiezers concentreert in plaats van op de uitbouw van de partijorganisatie en op discussies met de ongetwijfeld grote toestroom leden uit alle uithoeken van het land. Voor de PVV komt daar nog bij dat de aanhang voor een groot deel lijkt te bestaan uit ambitieuze mannen van middelbare leeftijd die graag in het middelpunt van de belangstelling staan, maar zich weinig plegen aan te trekken van het oordeel van anderen, ${ }^{128}$ wat het opzetten van een goed functionerende ledenorganisatie er niet gemakkelijker op zal maken. Voor een definitief oordeel lijkt het om al deze redenen te vroeg. Wat wel ergerlijk is, is dat er een spel wordt opgevoerd met juridische schijnconstructies, maar dát is nu juist veroorzaakt door de wetgever. Voor het aanzien van de politiek zou het misschien beter zijn om de eisen die de Kieswet aan naamsregistratie stelt, terug te brengen tot het vereiste van geregistreerde rechtspersoonlijkheid, vereniging of anderszins.

Dit alles neemt niet weg dat het beslist de voorkeur verdient als een partij probeert zo veel mogelijk gelijkgestemde leden te verwerven en ze die leden ook reële zeggenschap geeft binnen de partij.

De Venice Commission spreekt in dit verband van 'the basic intuitive concept of democratic organisation' en leidt daaruit af dat structuur en procedures van een politieke partij zeggenschap van de leden moeten waarborgen, dat partijorganen verantwoording en rekenschap moeten afleggen aan de leden, en dat statuten, programma en financiële verslagen openbaar moeten zijn. ${ }^{22}$ Met dit pleidooi stemmen wij van harte in. Een politieke partij die dit niet aandurft, is op den duur niet erg geloofwaardig. Voor het functioneren van het politieke bestel is het bovendien belangrijk dat mensen lid kunnen worden van de partij van hun keuze en daarbinnen kunnen deelnemen aan beraadslagingen over inhoudelijke thema's. Daarvoor zijn politieke partijen onmisbaar, juist omdat daarin het perspectief van nature gericht is op het bereiken van consensus over (een eigen visie op) het algemeen belang en niet uitsluitend op de handige behartiging van gegeven deelbelangen. De waarde daarvan kan in ons tijdsgewricht niet genoeg benadrukt worden.

Dit betekent echter niet zonder meer dat hier ook een opgave voor de wetgever ligt. De aangehaalde aanbevelingen van de Venice Commission staan in een tot de par-

Dat gold bijvoorbeeld ook voor de beginjaren van de in paragraaf 2 genoemde Antirevolutionaire Partij.

I28 Zie: 'Wilders in trek bij hoger opgeleide kiezer', Volkskrant 2I februari 2009 (gebaseerd op een onderzoek van TNS Nipo) en F. Spangenberg c.s. (Motivaction research \& strategy), De achterban van de PVV, Amsterdam 2009 (onderzoek in opdracht van het TV-programma Netwerk).

I29 Venice Commission 2009a, p. 9. 
tijen zelf gerichte gedragscode van de commissie. Aan de wetgevers van de lidstaten had de commissie eerder al eens een heel andere boodschap afgegeven:

'Matters of internal organisation of political parties, in principle, should not be subject to control by public authorities.'

Eventuele regels op dit punt moeten voldoen aan de maatstaf "necessary in a democratic society'. ${ }^{130}$ Die maatstaf noopt op dit moment in Nederland niet tot nieuwe wetgeving, lijkt ons. Dat zou misschien anders kunnen komen te liggen als het fenomeen van de ledenloze partij om zich heen zou grijpen, een permanent karakter zou krijgen en in handen zou dreigen te raken van vermogende geldschieters of baantjesjagers, iets waarvoor dit 'model' gevoeliger is dan de klassieke partijorganisatie. Maar ook dan is het voorschrijven van een ledenstructuur en interne democratie waarschijnlijk niet een effectieve oplossing. ${ }^{13 \mathrm{I}}$

\subsubsection{Het SGP-vrouwenstandpunt}

Ook de SGP had geen Nederlandse wet overtreden. ${ }^{132}$ Uit de uitlatingen en de gemoedsrust van de nationale wetgever mocht de SGP tevens afleiden dat er voor haar uit het Vrouwenverdrag niet rechtstreeks verplichtingen voortvloeiden. De uitspraak van de Hoge Raad komt er echter op neer dat de Nederlandse regering de betekenis van het Vrouwenverdrag voor de Nederlandse situatie kennelijk steeds verkeerd heeft beoordeeld en dat ze dus ook op verkeerde gronden heeft aangenomen dat een voorbehoud bij het verdrag op dit punt niet nodig was. De uitspraak is in veel opzichten voor tegenspraak vatbaar, zoals uit de gepubliceerde noten bij het arrest al kan worden afgeleid. ${ }^{\mathrm{I} 3}$ Dat gaan wij hier niet samenvatten of overdoen. In het kader van dit preadvies is vooral interessant hoe het college redeneert over de rol van politieke partijen bij het verzekeren van het passief kiesrecht en welk belang het hecht aan de zeer geringe omvang en het volstrekt ontbreken van enig wervingsvermogen van een orthodoxieconfessionele partij als de SGP.

Over het eerste punt redeneert de Hoge Raad als volgt: de uitoefening van het passief kiesrecht is in ons stelsel afhankelijk van kandidaatstelling door een politieke partij; daarom is het 'onaanvaardbaar dat een politieke groepering bij het samenstellen van de kandidatenlijst in strijd handelt met een grondrecht dat de kiesrechten van alle burgers waarborgt'. We hopen maar dat de Hoge Raad hier niet bedoelt (wat er wel lijkt te staan) dat elke partij zijn kandidatenlijsten zou moeten openstellen voor 'iedere Nederlander' aan wie krachtens artikel 4 van de Grondwet het passief

I30 Venice Commission 2004, p. 3.

I3I Zie hierover en over de neveneffecten en de effectiviteit van de Duitse regelgeving op dit punt, Elzinga 2008.

I32 Een eerdere poging om de partij strafrechtelijk vervolgd te krijgen wegens discriminatie strandde op inhoudelijke gronden. Zie Hof's-Gravenhage, 30 november 1995, NJ 1996, 324.

I33 Zie de laatste noot bij paragraaf 4.3. Daarnaast over eerdere uitspraken van andere rechters: Peters en Bleeker 2008, Kortmann 2008b, Busstra 2008, Dölle 2006. 
kiesrecht toekomt. Maar ook dan. Zoals de procureur-generaal in zijn conclusie ergens opmerkt, hebben vrouwen in de Nederlandse kieswetgeving reeds de mogelijkheid zich verkiesbaar te stellen en beschermt het passief kiesrecht het recht om aan de verkiezingen deel te nemen als kandidaat, niet het recht om aan de verkiezingen deel te nemen als kandidaat voor een bepaalde politieke partij. Vanwege de centrale rol die politieke partijen bij de kandidaatstelling spelen, gaat de Hoge Raad hieraan voorbij. Men kan zich afvragen of hij daarbij niet uitgaat van een veel te statisch beeld van het Nederlandse partijenstelsel. Anders gezegd: of hij niet de grote flexibiliteit miskent die aan dat stelsel inherent is, dankzij ons kiesstelsel (evenredige vertegenwoordiging met een zeer lage kiesdrempel), de verenigingsvrijheid (iedereen kan zonder veel moeite een partij oprichten) en ons kiesrecht (elke kiezer kan een kandidatenlijst indienen; zie paragraaf 3). Dat politieke partijen, bestaande of nieuwe, een centrale rol spelen bij de kandidaatstelling is in die situatie in feite een tautologie, omdat een groep mensen die met wat steun van anderen zichzelf kandideert, al per definitie een politieke partij is. Het is juist dankzij deze kenmerken van ons kiesstelsel dat een marginale groepering als de SGP steevast enkele van de 150 leden van de Tweede Kamer kan leveren.

Naar valt aan te nemen zou de Nederlandse regering wel degelijk actie hebben ondernomen als de SGP niet een zeer kleine partij was geweest uit een heel specifieke godsdienstige minderheidshoek met een stabiele aanhang en zonder enige wervingskracht bij andersdenkenden. Bij de implementatie van het Vrouwenverdrag is ze er kennelijk van uitgegaan dat de openstelling voor deelname door vrouwen niet noodzakelijk zonder enige uitzondering op alle partijen hoefde te slaan. In het geding bij de Hoge Raad heeft de Nederlandse Staat dit ook als reden aangevoerd met een beroep op de EHRM-uitspraak over de Turkse Refah Partij, waarin de omvang en wervingskracht van die partij, mede gelet op de historische context van de Turkse staat, belangrijke overwegingen waren voor het Hof om een partijverbod aanvaardbaar te achten. ${ }^{134}$ Dit argument van de Staat slaat niet aan doordat de procureur-generaal, het Hof 's-Gravenhage en (impliciet) de Hoge Raad een vergelijking met het partijverbod afwijzen en men verder niet meer op het punt ingaat. ${ }^{135}$ Meer in het algemeen valt op dat het belang van pluriformiteit in het politieke debat, dat door de regering werd aangevoerd en dat ook een belangrijke rol speelde in een eerdere uitspraak van de Afdeling bestuursrechtspraak van de Raad van State over subsidietoekenning aan de SGP, bij de burgerlijke rechter geen gewicht in de schaal lijkt te leggen. De procureur-generaal begrijpt het argument wel, waar hij de centrale vraag van het geding treffend als volgt formuleert:

'Is de democratische rechtsstaat meer gebaat met een gelijke toegang van mannen en vrouwen tot de kandidatenlijsten van alle politieke partijen, niet één partij uitgezonderd,

I34 Zie over deze uitspraak ook paragraaf 5.

I35 In Brems 2009, waarin een vergelijking wordt gemaakt tussen het 'dossier SGP' en het 'dossier Vlaams Blok', is de omvang van de partij wel een van de overwegingen om de SGP 'gelijk te geven' (en het Blok niet). 
óf is de democratische rechtsstaat meer gebaat met een pluriformiteit van politieke partijen waaruit de kiezers en kandidaat-volksvertegenwoordigers zelf een keuze kunnen maken en waar ruimte is voor een samenstelling van de lijsten van kandidaten voor verkiezingen die overeenstemt met het eigen politieke standpunt?' ${ }^{\prime 36}$

Hij doet daar echter niet veel mee en misschien kon hij dat cassatietechnisch ook wel niet meer. De vaststelling door het Hof's-Gravenhage dat de pluriformiteit niet in het geding was, leunde op diens twijfel aan het principiële karakter van het SGPstandpunt. De SGP kon in zijn ogen eenvoudig haar statuten en eventueel ook haar program van beginselen wijzigen en vervolgens gewoon haar standpunten blijven uitdragen in het parlement. ${ }^{137}$

Afijn, de uitspraak van de Hoge Raad is er. De vraag is nu welke gevolgen aan de uitspraak moeten worden verbonden. Hoe hebben de rechters zich dit eigenlijk voorgesteld? De uitspraak noch de eventueel daaruit voortvloeiende maatregelen, zullen de SGP-aanhang op andere gedachten brengen. Het tegendeel is eerder het geval. ${ }^{13^{8}}$ Dat betekent dat de wetgever in actie zal moeten komen. Betekent de uitspraak nu dat daaraan pas is voldaan als naar aanleiding van de door de Staat getroffen maatregelen de SGP niet meer meedoet aan de verkiezingen ofwel één van haar twee parlementszetels door een vrouw laat bezetten, die vervolgens van de rechter best het SGP-vrouwenstandpunt mag uitdragen? Of is het voldoende als vrouwen in de statuten van de SGP niet langer met zoveel woorden van de kandidaatstelling worden uitgesloten? Het eerste is alleen bereikbaar als voor alle fracties in de volksvertegenwoordiging een quotumregeling zou gaan gelden. ${ }^{139}$ Nog afgezien van de grondwettelijke aanvaardbaarheid van zo'n maatregel, lijkt de rechter een dergelijke vergaande maatregel niet voor ogen gehad te hebben, als wij tenminste aannemen dat de uitspraak niet onbegrijpelijk is. Met alleen statutenwijziging zou de SGP al, in de woorden van de Hoge Raad, het 'passief kiesrecht' aan vrouwen kunnen toekennen. Wij houden het erop dat dit voldoende is, temeer daar de Hoge Raad tevens als voorwaarde stelt dat 'de minste inbreuk' moet worden gemaakt op de grondrechten van (de leden van) de SGP. Bij het niet voldoen aan deze eis zijn als sancties eventueel denkbaar het niet kunnen registreren van de partijnaam of het vervallen of verminderen van de aanspraken op subsidie, al heeft het met de ratio van de desbetreffende regelingen weinig te maken. Beide typen sancties zijn uitvoerbaar en niet onoverkomelijk voor deelname aan de verkiezingen. ${ }^{\mathrm{I}{ }^{\circ} \mathrm{O}}$ Een inbreuk op de verenigingsvrijheid is een dergelijke maatregel wel. Daar staat dan tegenover

I36 Onderdeel 5.I4 van zijn conclusie. Cursivering is van de PG zelf.

I37 Overweging II in de uitspraak van het Hof. Van veel begrip voor het orthodox-protestantse milieu geeft de rechter in deze redenering niet blijk, in onze ogen.

I38 Zie over het daarnaar gedane onderzoek Oomen 2010.

I39 Een quotum voor alleen de kandidatenlijsten zal geen gegarandeerd effect hebben omdat het eenvoudig is voor een goed georganiseerde kleine partij om de zetelbezetting daarvan te laten afwijken.

I40 Zie hierover ook Schutgens \& Sillen 2010. 
dat een steen des aanstoots voor veel vrouwen- en grondrechtenorganisaties ermee zou zijn weggenomen, maar meer waarschijnlijk ook niet.

En wat als het om een veel grotere partij zou gaan die wel aanzienlijke wervingskracht zou blijken te hebben? In zo'n, gelukkig hypothetisch, geval zouden de afwegingen anders kunnen komen te liggen. Dan zouden meer of minder dwingende maatregelen in overweging genomen moeten worden, en dan zou uiteindelijk zelfs een partijverbod kunnen voldoen aan het criterium 'necessary in a democratic society'. Dat was uiteraard het punt dat de regering tegenover de rechter heeft geprobeerd te maken met haar beroep op de Refah Partisi-uitspraak van het EHRM.

\section{$5 \quad$ Het partijverbod}

\section{I Inleiding}

In de afgelopen jaren is in de Tweede Kamer verschillende keren de vraag aan de orde geweest of politieke partijen wier doelstellingen in strijd zijn met de beginselen van de democratische rechtsstaat, verboden moeten worden en of daarvoor wel toereikende instrumenten aanwezig zijn in het Nederlandse recht. Deze discussie werd telkens aangezwengeld door de cultureel meer behoudende fracties. Anders dan vroeger, ging het daarbij niet in de eerste plaats om een eventueel verbod van rechts-radicale en racistische groeperingen, maar om de vrees voor het ontstaan van of zelfs de dreigende oprichting van islamitische partijen met radicale standpunten. Sinds $200 \mathrm{I}$ is dit bij herhaling aan de orde geweest in Kamerdebatten over terrorismebestrijding ${ }^{\mathrm{II}}$ en verder onder meer in 2003 in Kamervragen van het lid Eerdmans (Lijst Pim Fortuyn) over de voorgenomen oprichting van een Nederlandse tak van de Arabisch Europese Liga (AEL), ${ }^{\text {I42 }}$ in 2005 in het debat over de regeringsnota Grondrechten in een pluriforme samenleving, ${ }^{143}$ in 2006 in een debat naar aanleiding van uitspraken van de minister van Justitie over de sharia, ${ }^{144}$ en in 2007 naar aanleiding van een nota van de Christendemocraten (CDA) over weerbare democratie $^{\mathrm{I} 45}$ en naar aanleiding van het kabinetsstandpunt over het rapport Dynamiek in islamitisch activisme van de Wetenschappelijke Raad voor het Regeringsbeleid. ${ }^{14^{6}}$ In 2006 is aan deze discussie de casus toegevoegd van de oprichting van de Partij voor Naastenliefde, Vrijheid en Diversiteit, die seksuele omgang met minderjarigen en het bezit van kinderpornografie uit het Wetboek van Strafrecht wilde verwijderen. ${ }^{\text {I47 }}$

I4I Kamerstukken 29754.

I42 Aanhangsel Handelingen 2002-2003, nr. I300.

I43 Kamerstukken 296 I4.

I44 Kamerstukken 30697.

I45 Kamerstukken 30449 .

I46 Kamerstukken II 2006-2007, 30 80o VI, nr. II5.

I47 Zie vragen van het Kamerlid Wilders (Groep Wilders), Aanhangsel Handelingen 2005-2006, nr. I859; van het lid Van der Staaij (SGP), Aanhangsel Handelingen 2005-2006, nr. I860; en van de leden Arib en Dubbelboer (beiden PvdA), Aanhangsel Handelingen 2005-2006, nr. 2079. 
Vooral de christendemocratische fractie maakt zich sterk voor ruimere mogelijkheden voor een partijverbod dan Nederland thans kent of althans in praktijk brengt. Zij verwijst daarbij naar de Duitse (grond)wetgeving en naar de uitspraak van het Europese Hof voor de Rechten van de Mens uit 2003 over het Turkse verbod van de Refah Partij. ${ }^{148}$ In zijn advies van april 2008 over de opdracht aan de Staatscommissie Grondwet wees de Raad van State eveneens op deze uitspraak. De Raad leidde daaruit af, dat het EVRM toelaat dat van politieke partijen respect wordt verlangd voor de democratie en de rechten en vrijheden die in een democratie worden erkend, en hij pleitte ervoor te onderzoeken of het aanbeveling verdient in de Nederlandse Grondwet een regeling op te nemen inzake de rol van politieke partijen binnen de democratische rechtsstaat. ${ }^{149}$ Het onderwerp is uiteindelijk niet in de opdracht aan de Staatscommissie Grondwet opgenomen. ${ }^{150}$

\subsection{Het partijverbod naar positief recht}

Een politieke partij, aannemend dat zij rechtspersoonlijkheid heeft, kan in Nederland bij rechterlijke uitspraak worden verboden verklaard en ontbonden als haar werkzaamheid in strijd is met de openbare orde (Burgerlijk Wetboek, artikel 2:20, eerste lid). De rechter kan hiertoe slechts overgaan op verzoek van het Openbaar Ministerie. Spreekt hij een verbodenverklaring uit, dan moet hij de rechtspersoon tevens ontbinden. Wanneer alleen het doel van de rechtspersoon in strijd is met de openbare orde, kan dit niet leiden tot een verbodenverklaring, maar slechts tot ontbinding (artikel 2:20, tweede lid). De rechter moet de rechtspersoon in dat geval in beginsel nog de gelegenheid geven om zijn doelstellingen aan te passen.

De betrokken bepaling ziet niet speciaal op politieke partijen, maar betreft alle soorten rechtspersonen. Ze heeft een plaats in het Burgerlijk Wetboek sinds 1976. De uit 1855 stammende verbodsprocedure van de Wet vereniging en vergadering ${ }^{151}$ kwam daarmee te vervallen. De regeling in het Burgerlijk Wetboek is sinds 1976 alweer enkele malen gewijzigd en ook vernummerd. In 1988 vond een voor ons onderwerp belangrijke wijziging plaats (wetsvoorstel 17476 ). Deze wijziging had tot doel het verhelpen van onvolkomenheden in de regeling die aan de dag waren gekomen bij een uitspraak van de Rechtbank Amsterdam in 1978, waarin de rechtbank weliswaar vaststelde dat de Nederlandse Volksunie een verboden karakter had, maar deze vaststelling zonder rechtsgevolgen bleef. ${ }^{152}$ Bij de behandeling van het wetsvoorstel gingen de Tweede Kamer en daarna (pas in de memorie van antwoord) ook de regering uitgebreid in op de betekenis van de bepaling voor de positie van politieke partijen.

I48 EHRM I3 februari 2003, 4I340/98, 4I342/98, 4I343/98 and 4I344/98 (Refah Partisi tegen Turkije).

I49 Kamerstukken II 2007-2008, 3I 570, nr. 3, p. 20.

I50 Zie daarover het slot van paragraaf 2.

I5I Wet van 22 april I855, Stb. 32, tot regeling en beperking der uitoefening van het regt van vereeniging en vergadering.

I52 Rb Amsterdam, 8 maart I978, NJ I978, 28I, en HR 9 maart I979, NJ I979, 363, beide m.nt. Maeijer. Zie daarover Elzinga I982 p. I3I-I33, en ook, zeer uitgebreid, Eskes I988, p. 435-46o. 
Met de term 'openbare orde' is aansluiting gezocht bij artikel 8 van de Grondwet, waarin de vrijheid van vereniging is gegarandeerd. ${ }^{153}$ Noch de grondwetshistorie, noch een vergelijking met het gebruik van dezelfde term in andere grondwetsartikelen, geven veel houvast bij de interpretatie ervan. Het is een verzamelterm waar zeer uiteenlopende zaken onder kunnen vallen en waar in de loop van de tijd ook zeer uiteenlopende zaken onder zijn gebracht. ${ }^{154}$ In het Burgerlijk Wetboek, waarin de term ook in andere bepalingen voorkomt, zoals die over nietige rechtshandelingen (artikel 3:40), pleegt er echter een zeer beperkte uitleg aan te worden gegeven. ${ }^{155}$ Beperkter dan strijd met de wet en beperkter dan aantasting van andermans rechten, aldus de regering in haar memorie van antwoord. ${ }^{156} \mathrm{Om}$ daarover geen twijfel te laten bestaan, gaf ze in die memorie naar vermogen een zo volledig mogelijke - maar niet limitatief bedoelde - opsomming van wat in dit verband kon worden verstaan onder strijd met de openbare orde. In de literatuur en de jurisprudentie wordt die opsomming vaak volledig geciteerd en wij doen dat hier ook maar even, al lijken niet alle genoemde gronden voor politieke partijen even relevant:

\begin{abstract}
'Slechts handelingen die inbreuk maken op de algemeen aanvaarde grondvesten van ons rechtsstelsel, kunnen het verbod van een vereniging of andere rechtspersoon rechtvaardigen: ongerechtvaardigde aantasting van de vrijheid van anderen of van de menselijke waardigheid. Gebruik van geweld of bedreiging daarmee tegen het openbare gezag of tegen degenen met wier opvattingen men het, al dan niet op goede gronden, oneens is, valt eronder, evenals rassendiscriminatie en andere verboden discriminatie. Evenzo het heulen met een mogendheid waarvan valt te verwachten dat zij een geboden kans om ons volk te onderdrukken zou grijpen, het weerstreven van onherroepelijke rechterlijke uitspraken of onrechtmatige benadeling van anderen als middel om het bestaan van de rechtspersoon te rekken. Het stelselmatig niet afdragen van premies en frauderen valt daaronder. Ten slotte behoren als strijdig met de openbare orde en de goede zeden te worden aangemerkt uitlatingen zoals het aanzetten tot haat en uitingen die verboden discriminatie inhouden of een mensonterend streven zoals het in de literatuur gegeven voorbeeld van een pleidooi om het doden van bepaalde volksgroepen straffeloos te maken. Al deze voorbeelden hebben gemeen dat zij een aantasting inhouden van de als wezenlijk ervaren beginselen van ons rechtsstelsel die, indien op grote schaal toegepast, ontwrichtend zou blijken voor de samenleving.' ${ }^{157}$
\end{abstract}

Andersom zag de regering strijd met de wet kennelijk wel als een noodzakelijke (zij het dus nog niet een voldoende) voorwaarde voor een partijverbod, al hield ze daarbij een kleine slag om de arm, waar ze in dezelfde memorie van antwoord stelde:

I53 Artikel 8 Grondwet luidt: Het recht tot vereniging wordt erkend. Bij de wet kan dit recht worden beperkt in het belang van de openbare orde.

I54 Zie voor een overzicht Burkens I97I, p. 57-75.

I55 Kamerstukken I I986-I987, I7 476, nr. 57b, p. 4.

I56 Kamerstukken II I984-I985, I7476, nrs. 5-7, p. 2.

I57 Kamerstukken II I984-I985, I7476, nrs. 5-7, p. 3. 
'een politiek programma dat langs wettige weg wordt nagestreefd, kan nauwelijks tot verbodenverklaring leiden'. ${ }^{158}$

De gevolgen van verbodenverklaring en ontbinding zijn ten eerste burgerrechtelijk. Door de ontbinding komt de rechtspersoon in een toestand van liquidatie te verkeren en na vereffening houdt hij op te bestaan. ${ }^{59}$ De verbodenverklaring heeft burgerrechtelijk geen gevolgen. In het strafrecht is dat precies andersom. Deelneming aan de voortzetting van de werkzaamheid van een organisatie die bij onherroepelijke rechterlijke beslissing verboden is verklaard, is een misdrijf (Wetboek van Strafrecht, artikel I40, tweede lid). ${ }^{160}$ De memorie van antwoord bij wetsvoorstel 17476 sprak in dit verband van 'het opzettelijk schenden van een op grond van (...) het Burgerlijk Wetboek uitgesproken verbodenverklaring'. ${ }^{6 r}$ Van de politieke groepering die als vereniging bij onherroepelijke rechterlijke uitspraak verboden is verklaard en deswege is ontbonden, wordt verder de aanduiding van de naam uit het desbetreffende register geschrapt door het centraal stembureau (Kieswet, artikel G I, zevende lid, G 2, zevende lid, en G 3, zevende lid). Het stembureau maakt dit bekend in de Staatscourant. Het schrappen van de naamsaanduiding heeft drie gevolgen. Ten eerste kan niemand meer onder de desbetreffende of een daar sterk op gelijkende benaming deelnemen aan verkiezingen. Daarnaast is de groepering per definitie geen politieke partij meer in de zin van de Wet subsidiëring politieke partijen (artikel I, onderdeel b), en van de Mediawet 2008 (artikel I, eerste lid), waarmee dus ook het recht op subsidie en op zendtijd vervalt. ${ }^{162}$ Voor het Kamerlidmaatschap heeft een en ander geen gevolgen. Daarover moeten de kiezers oordelen en niet de rechter. ${ }^{1{ }^{6} 3}$

Anders dan de tot 1976 geldende Wet vereniging en vergadering ${ }^{164}$, die eenvoudigweg van verenigingen sprak, is de regeling in het Burgerlijk Wetboek beperkt tot rechtspersonen. Dat roept de vraag op of men verbodenverklaring of de gevolgen daarvan kan voorkomen door zelf schielijk de rechtspersoon te ontbinden of door te voorkomen dat men rechtspersoonlijkheid verkrijgt. Volgens De Monchy en Snijder-Kuipers is verbodenverklaring van een intussen ontbonden rechtspersoon denkbaar, omdat de wettekst en de parlementaire geschiedenis geen duidelijke aanwijzing voor het tegendeel bevatten en een andere uitkomst (niet-ontvankelijkheid van het OM)

I58 Kamerstukken II I984-I985, I7476, nrs. 5-7, p. I4.

I59 Asser-Maeijer 1997, p. I77.

I60 In het Nederlandse strafrecht is een 'misdrijf' een relatief zwaar strafbaar feit. Lichtere strafbare feiten worden aangeduid als overtredingen.

I6I Kamerstukken II I984-I985, I7476, nrs. 5-7, p. 20.

I62 Daarnaast en dus zonder ontbinding van de rechtspersoon, kunnen zowel de subsidiëring als de zendtijdtoedeling tijdelijk vervallen wanneer de partij (als rechtspersoon) is veroordeeld tot een onvoorwaardelijke geldboete voor een van de discriminatiedelicten van het Wetboek van Strafrecht. Zie ook paragraaf 6.

I63 Kamerstukken I I986-I987, I7 476, nr. 57b, p. 5 .

$\mathrm{I} 64$ De tekst van die wet is opgenomen onder de bijlagen in Eskes I988. 
zeer onbevredigend zou zijn. ${ }^{165}$ Daarmee blijft strafrechtelijke vervolging wegens deelneming aan de voortzetting van de rechtspersoon (artikel I40, tweede lid) dus mogelijk. Zonder ontbinding door de rechter lijkt het echter de vraag of datzelfde kan worden volgehouden voor de gevolgen die de Kieswet en de Wet subsidiëring politieke partijen verbinden aan de verbodenverklaring en de ontbinding 'deswege'.

Het voorkomen van verbodenverklaring en ontbinding door rechtspersoonlijkheid te vermijden, is in het Nederlandse rechtspersonenrecht nagenoeg onmogelijk, aldus de minister van Justitie bij de behandeling van wetsvoorstel I7476: een bestendige organisatie, waarin volgens vaste, al dan niet geschreven regels taken worden verdeeld en besluiten worden genomen, kan er in Nederland nauwelijks aan ontkomen om als rechtspersoon te worden aangemerkt. ${ }^{166}$

\section{$5 \cdot 3$ De praktijk}

Afgezien van de Nationaal Socialistische Beweging in Nederland (NSB), die in 1944 door de regering werd verboden, ${ }^{167}$ is in de periode tot aan 1988 twee keer een partij verboden door de rechter: in 1894 de Sociaal Democratische Bond op basis van de Wet vereniging en vergadering en in 1953 de Nationaal Europese Sociale Beweging op basis van het NSB-besluit uit 1944, omdat deze een voortzetting van de NSB was. In 1978 , in de hiervoor al vermelde procedure op grond van de nieuwe regeling in het Burgerlijk Wetboek, kwalificeerde de rechtbank ook de Nederlandse Volksunie (NVU) als een verboden vereniging, maar die kwalificatie bleef zonder rechtsgevolgen doordat de rechtbank de rechtspersoon niet tevens ontbond. ${ }^{168}$ De in 1988 verbeterde wettelijke regeling in het Burgerlijk Wetboek is tot nu toe eenmaal toegepast: in 1999 werd de Nationale Volkspartij/CP'86 (CP'86) door de rechter verboden verklaard en ontbonden. ${ }^{169}$

Zowel de uitspraak over de NVU als die over de NVP/CP'86 laat zien dat de rechter de nodige aarzelingen moest overwinnen om deze stap te zetten. ${ }^{100}$ In de NVUzaak gaat de rechtbank zeer uitgebreid in op de hele historie van het partijverbod in Nederland en op de totstandkomingsgeschiedenis van de regeling in het Burgerlijk Wetboek. Hij concludeert daaruit dat de voor het leven benoemde rechter in een democratische samenleving als de Nederlandse een bijzondere terughoudend-

I65 De Monchy 20I0, Aantekening 3. In een van de hierna te bespreken zaken (CP'86) lijkt dit aan de orde te zijn. Volgens een bij de rechtbank binnengekomen bericht van het bestuur van de partij, kon deze zich de moeite besparen daar de vereniging inmiddels, maar na de start van de procedure, al ontbonden was. Zowel rechter als OM negeren dit volledig.

I66 Kamerstukken II I985-I986,I7476, nr. I2, p. 5. Zie ook paragraaf 4.

I67 In het Londense Besluit ontbinding landsverraderlijke organisaties, Stb. E I02, dat pas in I988 werd ingetrokken. Het verbod trof naast de NSB ook veertig met die partij verbonden organisaties, alsmede alle organisaties die het streven van een of meer van de ontbonden organisaties trachten voort te zetten.

I68 Zie de vermelding 'sinds I97I', direct onder het logo van de partij op de huidige website van de NVU, www.nvu.info.

I69 Rechtbank Amsterdam I8 november 1998, NJ I999, 377 en AB I999, 329 (m.nt. Kanne).

I70 Dat was ook al het geval bij het verbod van de Sociaal-Democratische Bond in I894. Zie Eskes I988, p. 49 . 
heid in acht heeft te nemen bij het vormen van zijn oordeel in dit soort kwesties, omdat de formulering van de wettelijke verbodsgrond vaag is en de rechter voor zijn beslissingen aan geen minister of gekozen college verantwoording schuldig is. Het zijn vervolgens het onversneden racistische karakter van de NVU-uitingen en de door deze organisatie gehanteerde agitatiemethoden (tezamen 'van een aan het misdadige grenzende en potentieel gevaarlijke aard') die de rechter doen concluderen dat hij toch buiten twijfel de NVU kan kwalificeren als een verboden vereniging. Daarbij zal geholpen hebben dat de voorzitter van de partij, Glimmerveen, al tot tweemaal toe wegens rassendiscriminatie was veroordeeld.

Ook aan de uitspraak in de CP'86-zaak was al het nodige voorafgegaan, zoals de rechtbank vaststelde:

'Diverse (oud)bestuursleden en leden (...) zijn veroordeeld wegens strafbare feiten gepleegd in de periode 1994 tot en met 1996 , welke feiten onder meer daarin bestaan dat zij zich schuldig hebben gemaakt aan het zich opzettelijk beledigend uitlaten over een groep mensen wegens hun ras, godsdienst of levensovertuiging en/of het aanzetten daartoe onder meer in het kader van activiteiten ten behoeve van de politieke partij CP'86.'

Door de discussies die aan de wetswijziging van 1988 waren voorafgegaan, had de rechter in deze zaak meer houvast dan zijn collega in de NVU-zaak. Hij stelde vast dat, blijkens die wetsgeschiedenis, het bij herhaling aanzetten tot en het uitlokken en propageren van discriminatie, ook bij een zeer restrictieve interpretatie van het begrip openbare orde in ieder geval onder deze verbodsgrond vallen. De stelselmatigheid en onverbeterlijkheid van dit gedrag bestempelden het tot een 'werkzaamheid' in de zin van de bepaling in het Burgerlijk Wetboek en daarom werd de partij verboden verklaard en ontbonden.

De impact van beide uitspraken valt moeilijk vast te stellen. De NVU heeft jaren onder interne twisten geleden, maar is sinds 1996 weer actief. Ze deed de afgelopen jaren enkele keren mee aan verkiezingen voor gemeenteraden en provinciale staten, maar heeft nimmer een zetel behaald. Verder houdt ze zo nu en dan een openbare demonstratie waar doorgaans meer tegendemonstranten en politieagenten aanwezig zijn dan NVU-deelnemers. Een deel van de aanhangers van CP'86 heeft de activiteiten voortgezet in allerlei splintergroeperingen die geen politieke deelname meer leken na streven en die meestal na korte tijd weer aan onderlinge twisten ten onder gingen, maar dat proces was al lang en breed aan de gang voordat de rechterlijke ontbinding werd uitgesproken. Een veroordeling voor deelneming aan de voortzetting van de verboden verklaarde rechtspersoon is voor zover wij weten nimmer aan de orde geweest.

Duidelijk is, dat volgehouden, openlijke en agressieve discriminatie op grond van ras of herkomst een partij in aanmerking kunnen doen komen voor een verbod. ${ }^{171}$

I7I Vanaf I97I werd rassendiscriminatie zelfs met zoveel woorden vermeld in de Wet Vereniging en Vergadering die in dat jaar was aangepast in verband met het Internationaal verdrag inzake de 
Bij stelselmatige intimidatie of geweldgebruik door een politieke partij, of het uitlokken van ernstige delicten, laat zich eenzelfde gedachtegang voorstellen. Dat wil overigens niet zeggen dat het Openbaar Ministerie in dergelijke gevallen snel een verzoek tot verbodenverklaring en ontbinding zal doen. Men wil uit de aard der zaak niet het risico lopen van een mislukt verzoek en zoekt zijn heil daarom liever in andere bepalingen van het Wetboek van Strafrecht, zoals de CP'86-casus duidelijk laat zien: pas na verschillende veroordelingen en nadat in I997 zelfs de bestuursleden van de partij en de partij zelf waren veroordeeld voor deelneming aan een misdadige organisatie op grond van artikel I40, eerste lid, van het Wetboek van Strafrecht, ${ }^{172}$ en er bovendien vanuit de Tweede Kamer zware druk was uitgeoefend om na alle veroordelingen tevens een verbodsactie in te stellen, durfde men uiteindelijk een verbodsactie aan, of kon men er althans niet meer onderuit. ${ }^{173}$ In de gedachtewisselingen met de Kamer hierover noemde de regering steeds als voorwaarde voor een verbodsactie dat sprake moet zijn van 'stelselmatige, zeer ernstige verstoring van het democratisch proces', daarbij overigens ontkennend dat dit een inperking zou inhouden ten opzichte van de oorspronkelijk beoogde reikwijdte van de betrokken bepaling. ${ }^{174}$

De nauwe band met het strafrecht en vooral ook de voorkeur voor het, in voorkomend geval, benutten van de 'normale' strafrechtelijke mogelijkheden, blijkt een constant gegeven in de benadering van Justitie. De minister van Justitie sprak deze voorkeur al uit tijdens de behandeling van wetsvoorstel I7476: die aanpak leek hem doeltreffender en daarom aantrekkelijker dan het bewerkstelligen van een burgerrechtelijke verbodenverklaring, waaraan hij om die reden eigenlijk geen behoefte had. ${ }^{175}$ Dezelfde voorkeur komt naar voren in de veel recentere antwoorden op Kamervragen over de aangekondigde oprichting van een Nederlandse tak van de Arabisch Europese Liga en van een 'pedofielenpartij'. ${ }^{176}$ Het feit dat het OM de afgelopen jaren bij de burgerrechtelijke aanpak van terrorisme en criminaliteit enkele malen zijn hoofd heeft gestoten bij verzoeken tot verbodenverklaring en ontbinding van omstreden rechtspersonen, ${ }^{177} \mathrm{zal}$ deze voorkeur slechts versterkt hebben.

uitbanning van alle vormen van rassendiscriminatie, maar bij de integratie van het verbodsregime in het Burgerlijk Wetboek werd het niet meer nodig geacht om deze specificatie met zoveel woorden in de wet op te nemen. Zie o.a. Kamerstukken II I985-I986, I7 476, nr. I2, p. 2.

I72 Hoge Raad 30 september 1997, NJ I998, II8.

I73 Zie het antwoord op de vragen over CP'86 van 3 oktober 1997 van de Kamerleden Rehwinkel (PvdA), Koekkoek (CDA), De Graaf (D66) en Oedayraj Singh Varma (GroenLinks), Aanhangsel Handelingen I997-I998, nr. 290.

I74 Zie o.a. de antwoorden op vragen van het lid Rehwinkel van 26 april I996 (Aanhangsel Handelingen I995-I996, nr. 1303), de brief van de Minister van Binnenlandse Zaken van I7 september 1996 over optreden tegen extremistische groeperingen (Kamerstukken II 1996-I997, 25 033, nr. I) en het verslag van een Algemeen Overleg daarover op 28 november 1996 (Kamerstukken II I996-I997, 25 033, nr. 2).

I75 Handelingen II, 22 september 1986 UCV I, p. I-22.

I76 Aanhangsel Handelingen II, 2005-2006, nrs. I859, I860 en 2079.

I77 Zie Rechtbank Amsterdam 3I maart 2005, NJF 2005, I8I en Hof Amsterdam, 5 januari 2006, NJF 2006, 28I, beide over de o.a. op de VN-Sanctielijst opgenomen stichting Al Haramain, alsmede Hoge Raad 26 juni 2009, NJ 2009, 396, over de stichting en vereniging Hells Angels in Harlingen. Daarover ook Kamervragen van het lid Wilders (Groep Wilders) van I2 januari 2006, Aanhangsel 
In de huidige situatie lijkt hiermee het bereik van de verbodsmogelijkheid wel ongeveer geschetst: ze figureert in feite als een extraatje naast en na de strafrechtelijke mogelijkheden om gedragingen van een rechtspersoon, zijn bestuurders of zijn leden te sanctioneren. Bij een partij die geen parlementszetels heeft en die dus geen subsidie ontvangt en geen zendtijd krijgt toegewezen, is bovendien het effect van verbodenverklaring vooral symbolisch, wat de animo van rechter noch OM zal versterken. Heeft een partij wel Kamerzetels verworven en kan zij dus kennelijk rekenen op steun onder een deel van de kiezers, dan maakt dat gegeven het voor Openbaar Ministerie en rechter alleen al daarom extra lastig. In de (sterke) bewoordingen van Löwensteyn, naar aanleiding van de NVU-zaak, kan dit ook als volgt worden samengevat: 'Wie de staatkundige problematiek door middel van "Generalklauseln" naar de rechter afschuift, pleegt roofbouw op het rechterlijk gezag. In een zo essentieel politieke materie als de onderhavige ligt het echter in de rede, dat de rechter op zijn gezag geen roofbouw laat plegen, dat hij om de politieke voetangels en klemmen heenloopt met dezelfde grote boog, waarmee de wetgever die zelf heeft ontweken, dat hij de hem ter hand gestelde criteria op marginale wijze hanteert. ${ }^{178}$

\subsection{Is een andere toepassing van het partijverbod voorstelbaar?}

Kort samengevat, blijken we het eigenlijk wel zonder de mogelijkheid van een partijverbod te kunnen stellen, althans in de welvarende en vredige halve eeuw die achter ons ligt. Het rechts-radicalisme bleef beperkt tot steeds weer andere excentrieke splintergroeperingen die in voorkomend geval door hun onbezonnen uitingen en gedragingen wel via het strafrecht konden worden aangepakt, en de enkele parlementaire partijen die een wat ongemakkelijke verhouding hadden tot de neutrale, pluralistische democratie (zoals de Communistische Partij Nederland) gedroegen zich netjes en bleken geen enkele wervende kracht buiten hun directe achterban te hebben. Zijn er omstandigheden denkbaar waarin dit anders zou komen te liggen? Wij zien die eerlijk gezegd niet op afzienbare termijn, maar op de wat langere termijn kan men zoiets natuurlijk nooit uitsluiten, zoals de historie genoegzaam heeft bewezen. Onder heel andere, zeer ongelukkige, maar niet perse onvoorstelbare omstandigheden is ook in Nederland een situatie denkbaar waarin langs democratische weg een groepering aan de macht komt die van plan is, teneinde 'orde op zaken te stellen', om grondrechten op te schorten, het parlement uit te schakelen en via machtigingswetten in feite dictatoriaal te regeren. Het is een illusie te denken dat de kiezer de opkomst van een dergelijke groepering in een vrije democratie altijd wel zal afstraffen. ${ }^{179} \mathrm{Kan}$ de huidige regeling van het partijverbod helpen om een dergelijke situatie tijdig te voorkomen, of is daarvoor misschien een andere vormgeving ervan nodig en is dat ook wenselijk? Dat zijn in feite de vragen die aan de orde waren in de Kamerdebatten die in de inleiding van dit hoofdstuk al werden vermeld.

Handelingen 2005-2006, nr. 956, en van het lid Van Haersma Buma (CDA) van 3 juni 2009, Aanhangsel Handelingen 2008-2009, nr. 3389.

I78 Löwensteyn I982.

I79 Zie voor een illustratie Haffner 2003. 
In de pleidooien van de Kamerfracties die voorstander lijken van een verruimde toepassing van het partijverbod, komen telkens twee elementen naar voren. Ten eerste willen zij kennelijk dat al kan worden ingegrepen op basis van uitsluitend de doelstellingen van een politieke partij, dus zonder dat er strafbare feiten zijn gepleegd. Dit zou bijvoorbeeld ook moeten kunnen 'wanneer hun doelstellingen onvermijdelijk tot strafbare feiten of het terzijde schuiven van onze democratische rechtsorde leiden'. Ten tweede pleiten zij voor preventief optreden tegen dergelijke partijen, dat wil zeggen dat in hun ogen in een 'weerbare democratie' niet gewacht wordt tot een beweging een zodanige omvang heeft dat ze een politieke factor van belang is geworden, maar dat er juist zo vroeg mogelijk wordt ingegrepen, om te voorkomen dát ze dat stadium ooit kan bereiken. Dit alles, omdat 'in onze democratie geen ruimte is voor groeperingen die de democratische rechtsorde willen gebruiken om diezelfde rechtsorde omver te werpen. ${ }^{180}$ De woordvoerders in de Tweede Kamer die hiertegen ingingen, spraken hun vertrouwen uit in het gezond verstand van de Nederlandse kiezers en in de reinigende werking van het openbare debat waarin onwelgevallige denkbeelden vanzelf worden ontmaskerd. Men hoeft dit optimisme niet te delen om in te zien dat er wel enige vraagtekens kunnen worden geplaatst bij de hier gedane voorstellen. Die vraagtekens zijn niet alleen principieel maar ook praktisch van aard.

De principiële kwestie bij dit onderwerp is steeds in hoeverre een democratische staat het risico loopt de democratie zelf te ondergraven, als hij 'ondemocratische' middelen, zoals een partijverbod, hanteert. Het Europese Hof voor de Rechten van de Mens acht een verbod onder omstandigheden toelaatbaar, maar zegt daar altijd bij dat ze dergelijke maatregelen zeer strikt toetst, vanwege de essentiële rol van politieke partijen voor het verzekeren van pluralisme en een goede werking van de democratie. ${ }^{\mathrm{I} 8 \mathrm{I}}$ Ook de meeste staatsrechtelijke schrijvers erkennen het recht op bescherming van de democratie door de staat en sommigen zien het zelfs als een plicht, maar voor zover ze zich erover uitlaten, dringen ze steevast aan op uiterste terughoudendheid daarbij. Zo waarschuwt Kortmann dat bij een te weinig behoedzaam overheidsingrijpen inzake politieke partijen, de machthebber van een bepaald ogenblik (wetgever of rechter) zijn begrip van recht en democratie gaat opleggen aan anderen, waardoor de democratie zelf gevaar loopt. ${ }^{182}$ Ook Koopmans waarschuwt voor oneigenlijke toepassing door de zittende politieke klasse die immers niet erg van nieuwkomers pleegt te houden. ${ }^{183}$ Burkens wijst erop dat niet goed valt aan te

I80 Citaten zijn ontleend aan de motie die Van Hearsma Buma (CDA), mede namens Wilders (Groep Wilders), Van der Vlies (SGP) en Herben (LPF) indiende in het debat over de sharia-uitspraak van de minister van Justitie, Kamerstukken II 2005-2006, 30 697, nr. 2. De motie werd door de Tweede Kamer verworpen. Wel aangenomen werd een motie van het lid Van Schijndel (Groep Van Schijndel) waarin de regering werd verzocht actiever gebruik te maken van de bevoegdheden om politieke verenigingen verboden te laten verklaren en te ontbinden, indien hun werkzaamheid gericht is op het omverwerpen van de democratische rechtsstaat. Zie Handelingen II, I4 september 2006, p. I07-6547.

I8I Van Dijk \& Van Hoof 2006, p. 828.

I82 Kortmann 2008, p. 226/227.

I83 Koopmans 1992. 
geven waar de grenzen liggen van toelaatbaar politiek streven. ${ }^{184}$ Het positieve recht biedt daarvoor zelf geen houvast, omdat het immers gewijzigd mag worden. ${ }^{185} \mathrm{Het}$ zoeken naar aanknopingspunten in achterliggende, meer fundamentele beginselen, zoals in de jaren dertig wel is bepleit, ${ }^{186}$ levert altijd arbitraire uitkomsten op. Het Duitse Bundesverfassungsgericht kwam hier volgens Burkens ook niet uit. Wat hij zich nog wel kan voorstellen, is dat aansluiting wordt gezocht bij de rechtswaarborgen die in internationale mensenrechtenverdragen 'notstandsfest' zijn verklaard. ${ }^{187}$ Elzinga is van oordeel dat het vraagstuk van ondemocratisch optreden alleen met rechtsmiddelen kan worden aangepakt als het zich beperkt tot uitgesproken minderheden en als er in de samenleving een grote mate van consensus bestaat over de fundamenten van de democratie. Maar ook dan moet volgens hem met partijverboden de uiterste terughoudendheid worden betracht, wil de democratie haar eigen legitimiteit niet ondergraven. Wanneer de maatschappelijke consensus over de democratie afbrokkelt, wordt de bedreiging van de democratie indringender en de noodzaak tot ingrijpen groter, maar de democratische legitimatie voor dat ingrijpen wordt juist geringer. In een dergelijke situatie valt een partijverbod, zo al mogelijk, volgens Elzinga niet meer te verdedigen. Pogingen om de ontwikkelingen dan nog met rechtsmiddelen te keren, zullen een neerwaartse spiraal in gang zetten die voor de democratie zelf fatale gevolgen kan hebben. ${ }^{188}$

Los hiervan lijken de wensen van de voorstanders van een verruimde toepassing van het partijverbod niet zonder meer realiseerbaar of zullen ze althans niet de ervan verwachte effecten kunnen hebben. Op zeker drie punten rijzen praktische bewaren. Het mogelijk maken van een vroegtijdig verbod op basis van uitsluitend de doelstellingen van een partij leidt om te beginnen tot tegenstrijdigheden met de vrijheid van meningsuiting en kan waarschijnlijk ook niet door de beugel van het Europese Hof voor de rechten van de mens (EHRM). Ten tweede is de verwachting dat een rechter met een dergelijke mogelijkheid iets zou doen, waarschijnlijk onterecht. Ten slotte kan getwijfeld worden aan de effectiviteit van een zodanig verbod, tenzij de daaraan te verbinden gevolgen aanzienlijk worden uitgebreid, wat weer op gespannen voet staat met het idee dat ingrijpen juist al vroegtijdig zou dienen plaats te vinden.

De Grondwet zegt er niets over, maar de huidige Nederlandse wetgeving staat geen verbodenverklaring toe op de enkele grond dat de doelstellingen van een rechtspersoon in strijd zijn met de openbare orde. In dat geval kan een rechtspersoon op zijn hoogst worden ontbonden, hetgeen slechts burgerrechtelijke gevolgen heeft.

I84 Burkens i989, p. I63-I65.

I85 Daarover ook Nieuwenhuis 2003.

I86 Door Van den Bergh in zijn oratie: Van den Bergh 1936.

I87 De 'notstandsfeste'-bepalingen volgens artikel I5 EVRM zijn het recht op leven (artikel 3), het verbod op marteling (artikel 4), het verbod op slavernij of lijfeigenschap (artikel 4, eerste lid) en het beginsel dat strafoplegging uitsluitend is toegestaan op basis van de wet (artikel 7). Artikel I4 IVBPR voegt daar onder meer nog aan toe de vrijheid van geweten en godsdienst.

I88 Elzinga I982, hoofdstuk 6. 
Alleen de werkzaamheid van een partij kan tot een verbodenverklaring leiden. $\mathrm{Nu}$ is de grens tussen doelstellingen en werkzaamheid bij een politieke partij nooit scherp te trekken. Een rechter zal de (werkelijke) doelstellingen altijd mede uit de werkzaamheid proberen af te leiden en, andersom, bestaat een groot deel van de werkzaamheid van een politieke partij uit de aard der zaak uit het op allerlei manieren actief uitdragen van de eigen doelstellingen. Toch zou het in de Nederlandse context, waarin aan politieke partijen geen wettelijke eisen worden gesteld, vreemd zijn als een opvatting die elke burger vrijelijk mag ventileren, ineens sancties uitlokt wanneer ze afkomstig is van een rechtspersoonlijkheid bezittend groepje dat zich politieke partij noemt en dat verder niets anders doet dan proberen om voor deze opvatting medestanders te vinden. De wens om vroegtijdig te kunnen optreden op basis van alleen partijdoelstellingen, vergt dus al gauw een bijzondere regeling van de positie en de verantwoordelijkheden van politieke partijen (en daarmee dus een definitie van het begrip 'politieke partij'). Dat zien we dan ook in de bekendste landen die het concept van de 'streitbare demokratie' hanteren (Duitsland sinds I948 en Turkije sinds I980). Voor zover de voorstanders van een verruimde verbodsmogelijkheid zich beroepen op de Duitse praktijk en op de uitspraak van het EHRM in de zaak Refah Partisi (Welvaartspartij) tegen Turkije, ${ }^{189}$ lijkt dat overigens maar voor de helft terecht.

In Duitsland is slechts tweemaal een partij verboden door het Bundesverfassungsgericht, beide gevallen kort na de Tweede Wereldoorlog. In de laatste uitspraak, het verbod van de Kommunistische Partei Deutschland in 1956, waar het gerecht met kennelijke tegenzin vijf jaar over heeft gedaan, overwoog de rechter dat het voor een verbod niet voldoende is als een partij de hoogste waarden van de Verfassungsordnung verwerpt, maar dat daarnaast sprake moet zijn van een actieve, vechtlustige en agressieve houding tegenover de bestaande orde en van het planmatig beïnvloeden daarvan (in dit geval door het voeren van een systematische hetze). ${ }^{190}$ Als daar sprake van was, was het verder niet van belang dat de partij naar menselijke maatstaven gemeten, geen enkel uitzicht had op het verwerkelijken van haar doeleinden.

In de uitspraak over het verbod van de Refah Partij hanteert de Grote Kamer van het EHRM als criteria dat een politieke partij alleen wettige en democratische middelen dient te gebruiken en dat de doelen die zij nastreeft verenigbaar moeten zijn met fundamentele democratische beginselen (alinea 98), maar als daaraan niet is voldaan, is daarmee nog niet de noodzaak van een verbod in een democratische samenleving aangetoond. In dezelfde uitspraak benadrukt het Hof dat die noodzaak alleen aanwezig is als aannemelijk is gemaakt dat 'the risk to democracy was sufficiently imminent' (alinea ro4). ${ }^{\text {19 }}$

I89 EHRM I3 februari 2003, nr. 4I344/98,4I343/98,4I342/98,4I340/98, LJN: AN7452; NJ 2005, 73 (m.nt. Alkema); AB 2003, I52 (m.nt. Kanne).

I9o De volledige uitspraak valt na te lezen via het project Verfassungsgeschichte van het Institut für Oeffentliches Recht van de Universität Bern: www.verfassungsgeschichte.ch.

I9I Onduidelijk blijft of de eis van een onmiddellijke bedreiging van de democratie eveneens opgaat als een partij het niet bij wettige en democratische middelen laat. Als dat zo is, zou het Nederlandse verbod van CP'86 waarschijnlijk al niet door de EHRM-beugel kunnen, al is het de vraag of betrokkenen in een dergelijk geval de bescherming van het EVRM zouden kunnen inroepen 
Ten slotte verdient nog vermelding dat de Venice Commission van de Raad van Europa in 1999 in haar richtlijnen over het onderwerp stelde dat een partijverbod alleen toelaatbaar is als een partij geweld propageert of gebruikt om de democratische constitutionele orde omver te werpen. ${ }^{\text {I92 }}$ Resolutie I308 (2002) van de Parlementaire Assemblée van de Raad van Europa, die op dit rapport is gebaseerd, stelt dat

'restrictions on or dissolution of political parties should be regarded as exceptional measures to be applied only in cases where the party concerned uses violence or threatens civil peace and the democratic constitutional order of the country.'

Zo veel mogelijk moet met minder radicale maatregelen worden volstaan (bijvoorbeeld intrekken van subsidies). Een partijverbod is ultimum remedium volgens de Assemblée ('a last resort').

Een ander probleem met de voorstellen is dat ze voorbij gaan aan het feit dat de rechter, zoals we hiervoor al vaststelden, begrijpelijkerwijs niet erg geneigd zal zijn om een verbodenverklaring uit te spreken en, bijgevolg, het Openbaar Ministerie dus niet om een verbodsactie te starten. Een mislukt verbod is in dit soort kwesties immers veel erger dan het niet geprobeerd te hebben. Als de verbodsgronden ook nog eens verruimd zouden worden, zal de animo van de rechter er niet groter op worden, omdat hij dan nog minder houvast heeft. Het is waarschijnlijk ook niet toevallig dat de staten die een uitgesproken strijdbare intentie hebben op dit punt (vooral Duitsland en Turkije), de beslissingen over partijverboden hebben opgedragen aan een constitutioneel hof, iets wat de Venice Commission in de eerder vermelde richtlijnen overigens ook aanbeveelt, maar wat Nederland (vooralsnog) niet heeft. In Duitsland heeft dat overigens de aarzelingen kennelijk niet doen wegnemen. In de literatuur wordt de lange duur van de hiervoor genoemde KPD-zaak hiermee in verband gebracht. Illustratief in dit verband is ook de openbare waarschuwing die de vicepresident van het Bundesverfassungsgericht begin 2009 in een kranteninterview uitte, inhoudende dat de drempel voor een eventueel verbod van de extreemrechtse Nationaldemokratische Partei Deutchlands (NPD) door het hof waarschijnlijk zeer hoog zou liggen. Hij deed dit nadat bekend was geworden dat de ministers van Binnenlandse Zaken van vijf bondslanden overwogen om een verbodzaak aanhangig te maken. ${ }^{193}$ Alleen Turkije lijkt op dit punt weinig aarzelingen te hebben. Voorafgaand aan het verbod van de Refah Partij had het Turkse constitutionele hof al veertien keer eerder een partij verboden, waarvan vier zaken het tot het EHRM hadden gebracht, die in alle vier die gevallen schending van het EVRM (artikel II) vaststelde. ${ }^{194}$ Anders

wegens artikel I7 EVRM. Vgl. ECRM II oktober 1979, Glimmerveen en Hagenbeek tegen Nederland, NJ I980, 525 .

I92 Venice Commission 1999.

I93 Vermeld in Vogel 2009. Daarin ook een uiteenzetting over een eerdere procedure om de NPD verboden te krijgen, die noodgedwongen werd opgeschort nadat geleidelijk bleek dat de te horen NPD-getuigen bijna allemaal voor de Duitse geheime dienst werkten.

I94 Gegevens ontleend aan de noot van Alkema onder NJ 2005, 73. 
dan bij de Refah Partij ging het in die andere zaken steeds om beginnende partijen die volgens de regering de Koerdische minderheid steunden of stimuleerden in hun streven naar een bijzondere status of naar afscheiding, wat als een bedreiging werd gezien voor de integriteit van de Turkse staat. Dat Turkije een apart geval is, wordt bevestigd in een rapport over de Turkse verbodswetgeving dat de Venice Commission in 2009 uitbracht op verzoek van de Parlementaire Assemblée van de Raad van Europa. De commissie concludeert daarin dat er in de wetgeving van de Europese landen over partijverboden geen enkele duidelijke Europese standaard valt te ontdekken, maar dat de praktijk die juist wel laat zien: wat er aan wetgeving op dit punt is, wordt niet toegepast. De enkele uitzondering op die regel bevestigt hem slechts. ${ }^{195}$

Uit de voorstellen voor een verruimde toepassing van het partijverbod spreekt ten slotte een vertrouwen in de effecten van het verboden verklaren en ontbinden van een partij, dat niet erg gerechtvaardigd lijkt. Als een partij toch al aan het desintegreren is, zoals CP' 86 destijds, dan kan een verbod misschien het laatste zetje zijn dat betrokkenen definitief ontmoedigt of uiteendrijft, al zal de bijdrage van een rechterlijke uitspraak daaraan wel nooit kunnen worden vastgesteld. Maar als het om een partij met een substantiële en gemotiveerde achterban gaat, en er dus echt redenen zouden zijn om zich zorgen te maken, dan zal een verbod in het Nederlandse systeem waarschijnlijk vooral een symbolische daad blijken. Een nieuwe partij is snel opgericht en het delict 'voortzetten van een verboden rechtspersoon' is niet eenvoudig te bewijzen als men er een beetje op bedacht is. Elzinga, die zelf trouwens niet in de effectiviteit van het instrument gelooft, wijst erop dat het Duitse KPDverbod naar verluidt voor die partij wel degelijk desastreuze effecten heeft gehad. ${ }^{196}$ Wat hij er niet bij zegt, is dat de gevolgen van een partijverbod in Duitsland (en ook in Turkije trouwens) aanmerkelijk ingrijpender kunnen zijn dan in Nederland. Naast de ontbinding van de rechtspersoon kan ook het vermogen van de partij worden geconfisceerd en kunnen volksvertegenwoordigers hun zetels kwijtraken. Het KPD-verbod ging verder vergezeld van een omvangrijke en langdurige praktijk van 'Berufsuerbote' waardoor de aanhangers van de partij geweerd konden worden uit een groot aantal betrekkingen. Dat soort maatregelen verhoogt de effectiviteit natuurlijk aanmerkelijk, ${ }^{197}$ maar de inzet ervan vergt dan ook een navenante legitimatie.

Samenvattend kan geconcludeerd worden dat we in Nederland gerust het Duitse model van de 'streitbare demokratie' zouden kunnen overnemen, inclusief de extra sancties die men daar aan het partijverbod heeft verbonden, maar dat het voor de

I95 Venice Commission 2009. Volgens de commissie betroffen de enkele recente gevallen over het algemeen extremistische groeperingen met weinig leden (Frankrijk, Italië). Het rapport vermeldt nog niet het Spaanse verbod van de Baskische partij Herri Batasuna in 2009.

I96 Elzinga I982, p. I46, noot 83 .

I97 Hoewel de Communistische Partij Nederland nooit verboden werd, gold tot I970 ook in Nederland een verbod voor ambtenaren in zogenoemde vertrouwensfuncties, op dat moment zo'n dertig procent van alle functies bij de rijksoverheid, om lid te zijn van die partij of van een van haar mantelorganisaties. Zie daarover Olde Kalter I979, p. 2 I9 e.v. 
praktijk vermoedelijk niets uitmaakt; nu niet en waarschijnlijk ook niet in onverhoopte tijden waarin het er echt om zou spannen. De politieke en maatschappelijke werkelijkheid en de door de rechterlijke onafhankelijkheid bepaalde speelruimte van de rechterlijke macht blijken meer bepalend voor de praktijk dan de wettelijke vormgeving van een partijverbod. Wat het staatsrecht betreft, zijn er andere punten die misschien eerder aandacht vragen voor het geval de maatschappelijke gemoedsbewegingen zich in een noodlottige richting zouden ontwikkelen. Bijvoorbeeld vasthouden aan de regel dat er twee lezingen en in tweede lezing een tweederde meerderheid nodig zijn voor een wijziging van de Grondwet. Daarnaast kan het onder onverhoopte omstandigheden belangrijk blijken te zijn dat de bevoegdheden op basis van de noodwetgeving niet te ruim zijn en dat de procedures om die wetgeving in werking te stellen en te houden met voldoende waarborgen zijn omgeven. Maar de val van de Weimar-republiek zou ook daarmee niet zijn voorkomen. Hoogstens had men meer moeite gehad om de schijn van legaliteit overeind te houden. Juist de Duitse geschiedenis leert dat het van groot belang is om radicalisering en extremisme in een zo vroeg mogelijk stadium tegen te gaan, maar daarvoor zijn heel andere en vooral ook zeer veel en zeer uiteenlopende maatregelen nodig. ${ }^{198}$

\section{De financiering van politieke partijen}

\section{I Inleiding}

In de afgelopen decennia is er in Nederland met enige regelmaat een discussie gevoerd over de subsidiëring en financiering van politieke partijen en over de vraag of wijziging van de wetgeving op dat punt wenselijk is. Politieke partijen in Nederland zijn grofweg van drie inkomstenbronnen afhankelijk: contributies, overheidssubsidies en donaties. Het aandeel van de inkomsten dat afkomstig is van private financiers, lijkt nooit overheersend te zijn geweest, behalve misschien bij de liberalen. ${ }^{199}$ Daarin is verandering gekomen met de opkomst van nieuwe populistische partijen die soms geen leden hebben en die daardoor contributies noch subsidies ontvangen. ${ }^{200}$ Deze ontwikkeling bracht een adviesraad van de regering onlangs tot de aanbeveling om ook partijen zonder of met weinig leden voor overheidssubsidie in aanmerking te laten komen. ${ }^{201}$

Tot nu toe zijn er in Nederland geen grote schandalen geweest rond de partijfinanciering. We kunnen echter niet met zekerheid zeggen dat daar ook helemaal nooit aanleiding voor geweest zou zijn. Buitenlandse schandalen kwamen veelal aan het licht na een onafhankelijke wettelijk verplichte controle van de financiering van politieke partijen. Doordat de wetgeving op dit punt in Nederland zeer summier is,

I98 Zie daarover o.a. de regeringsnota Radicalisme en radicalisering, Kamerstukken II 2004-2005, 29754 , nr. 26.

I99 Koole i992, p. Ior.

200 Voor subsidie komen alleen partijen in aanmerking die meer dan duizend leden hebben en die bovendien minstens één zetel hebben verworven in het parlement.

201 Raad voor het Openbaar Bestuur 2009, p. 64. 
kennen wij een dergelijke intensieve controle niet. We moeten ons voorstellingsvermogen gebruiken om ons af te vragen of de bekende buitenlandse voorbeelden zich ook in Nederland zouden kunnen voordoen. Ter inspiratie kan dan bijvoorbeeld dienen de CDU-Spendenaffäre in Duitsland, die voormalig Bondskanselier Helmut Kohl eind jaren negentig van de vorige eeuw in opspraak bracht omdat hij zijn partij illegaal met miljoenen liet financieren. ${ }^{202}$ Of de oud-premier van de Labour-party, Tony Blair, die in 1997 werd beschuldigd van het verlenen van gunsten in ruil voor donaties. ${ }^{203}$ Meer recent valt te wijzen op het gerucht dat de Oostenrijkse politicus Jörg Haider een geheime bankrekening zou hebben gehad met daarop miljoenen euro's die hij als steun uit het buitenland zou hebben ontvangen. ${ }^{204}$

Sinds 2008 wordt uit internationale hoek druk uitgeoefend op de Nederlandse regering om te komen tot nieuwe wetgeving op het gebied van de partijfinanciering. In dat jaar publiceerde de Groep van Landen tegen Corruptie (GRECO), een orgaan van de Raad van Europa, een zeer kritisch rapport over de wettelijke voorzieningen op dit punt in Nederland. ${ }^{205}$ De Nederlandse regering heeft aangekondigd met nieuwe wetgeving te zullen komen.

\subsection{Partijfinanciering naar positief recht}

Vanaf het begin van de jaren zeventig van de vorige eeuw worden politieke partijen in Nederland door de rijksoverheid financieel ondersteund. Aanvankelijk was die ondersteuning beperkt tot zogeheten 'indirecte' kosten, zoals wetenschappelijke activiteiten en jongerenorganisaties. ${ }^{206}$ In 1999 werd een nieuw subsidiesysteem geïntroduceerd, waardoor politieke partijen rechtstreeks en voor specifieke kosten overheidsgelden ontvangen: de Wet subsidiëring politieke partijen. ${ }^{207}$ De wet is na I999 enkele keren gewijzigd en geeft op dit moment een opsomming van tien soorten activiteiten waarvoor subsidie kan worden verstrekt: politieke vorming en scholing, informatievoorziening, contacten met zusterpartijen buiten Nederland, ondersteunen van vormings- en scholingsactiviteiten ten behoeve van het kader van zusterpartijen buiten Nederland, politiekwetenschappelijke activiteiten, bevordering van de politieke participatie van jongeren, werven van leden, betrekken van niet-leden bij subsidiabele activiteiten van de politieke partij, werving, selectie en begeleiding van politieke ambtsdragers en verkiezingscampagnes. ${ }^{208}$ Vooral door de opname van activiteiten in het kader van verkiezingscampagnes in dit lijstje, waaronder van alles kan vallen, kan de subsidie in feite worden gezien als een lump sum waaraan geen strikte voorwaarden zijn verbonden. ${ }^{209}$ In de afgelopen jaren zijn de subsidie-

202 Zie o.a. http://www.spiegel.de/thema/cdu_spendenaffaere/.

203 Zie o.a.: Secret papers reveal Tony Blair's Fi tobacco deal, in The Sunday Times, I2 oktober 2008.

204 'Weekblad: Haider had zwart geld in Liechtenstein' in NRC Handelsblad, 2 augustus 2010.

205 Group of States against Corruption, Evaluatierapport over Nederland inzake 'Transparantie in de financiering van politieke partijen', Straatsburg, I3 juni 2008, Greco Evaluation III Rep (2007) 8E.

206 Hierover: Dragstra 2008, p. 20 e.v. en Koole I992, p. I8I e.v.

207 Wet van I5 juni 1999, Stb. I999, 475. De naam is in de hiernavolgende noten afgekort tot: Wspp.

208 Artikel 5 Wspp.

209 Koole 2008. 
bedragen een aantal keren verhoogd. Vooral de verhoging die met de uitbreiding van de subsidiabele doeleinden gepaard ging, was aanzienlijk. ${ }^{210}$ Samen krijgen de politieke partijen sindsdien ongeveer 20 miljoen euro aan overheidssubsidie. In het kader van een algemene bezuinigingsronde heeft de regering in 2009 een verlaging van de subsidie voorgesteld. ${ }^{211}$

Niet alle politieke partijen komen voor subsidie in aanmerking. De wet ziet alleen op partijen die een zetel hebben in het parlement (Tweede Kamer en/of Eerste Kamer). Partijen die uitsluitend lokaal of regionaal actief zijn, kunnen er dus geen aanspraken aan ontlenen. Dat geldt ook voor nieuwe partijen die nog geen parlementszetel hebben verworven. Daarnaast moet een politieke partij ten minste duizend leden hebben om subsidie te kunnen krijgen. ${ }^{212}$ Deze eis is opgenomen om zogeheten 'lege-hulsconstructies' uit te sluiten: partijen die weinig meer inhouden dan een aan een Kamerfractie gelieerde organisatie zonder enige binding met de samenleving. ${ }^{213}$ Wanneer een partij op grond van strafrechtelijke discriminatiebepalingen onherroepelijk is veroordeeld, vervalt de subsidieaanspraak van rechtswege voor een bepaalde periode. ${ }^{214}$ Dit heeft zich overigens nog nooit voorgedaan.

In de verdeelsleutel voor de te verstrekken subsidies wordt rekening gehouden met het aantal parlementszetels, het aantal leden van de partij en het al of niet aanwezig zijn van een eigen politiekwetenschappelijk instituut en een jongerenorganisatie. ${ }^{215}$ Partijen moeten hun administraties, begrotingen, activiteitenplannen en financiële verslagen zodanig inrichten en bijhouden dat de gegevens die nodig zijn voor de vaststelling van de subsidieaanspraken en voor de controle op de besteding van de subsidies, daaruit blijken. ${ }^{26}$ De wet eist voorts dat de jaarrekening die het partijbestuur krachtens het Burgerlijk Wetboek elk jaar aan de algemene ledenvergadering moet overleggen, ${ }^{217}$ aan controle door een accountant wordt onderworpen. ${ }^{218} \mathrm{Bij}$ ministeriële regeling kunnen nadere regels worden gesteld over de reikwijdte en de intensiteit van het accountantsonderzoek. ${ }^{219}$

Naast subsidie in euro's kunnen partijen ook aanspraak maken op een vorm van subsidie in natura. Op grond van de Mediawet wordt elk jaar een aantal uur zendtijd op de publieke zenders verdeeld over de politieke partijen die bij de laatstgehouden verkiezingen zetels in het parlement hebben verworven. Ook hier geldt dat een

2I0 Wet van 30 juni 2005, Stb. 2005, 373.

2II Kamerstukken II 2008-2009, 3I 906, nrs. I-3. Dit wetsvoorstel is nog in behandeling in de Tweede Kamer.

2I2 Artikel 2, derde lid, Wspp.

2I3 Kamerstukken II I997-I998, 25 704, nr. 3, p. 7.

2I4 Artikel I6 Wspp.

2I5 Artikelen 5-7 Wspp.

2I6 Artikelen 8-Io Wspp. De administratie moet bovendien tien jaar bewaard worden.

2 I7 Burgerlijk Wetboek, Boek 2, artikel 49.

2I8 Artikel II, eerste lid, Wspp waarin artikel 2:393, van het Burgerlijk Wetboek van overeenkomstige toepassing is verklaard.

2I9 Artikel II, tweede lid, Wspp. Dat is gebeurd in de Regeling subsidiëring politieke partijen, 27 juli I999, Stcrt. I999, nr. I4I. 
veroordeling voor discriminatie tot gevolg heeft dat de aanspraken van een partij tijdelijk komen te vervallen. ${ }^{20}$

De Wet subsidiëring politieke partijen verplicht partijen voorts om bepaalde giften die zij ontvangen openbaar te maken. ${ }^{221}$ Deze verplichting geldt niet alleen voor partijen die subsidie ontvangen, maar voor elke partij die onder de begripsomschrijving van de wet valt. In de praktijk zijn dat alle partijen die met enige kans op succes aan de parlementsverkiezingen meedoen. ${ }^{222}$ Elke gift aan een politieke partij van $4.537,80$ euro of meer die niet afkomstig is van een natuurlijke persoon, moet door de partij openbaar worden gemaakt. Die openbaarmaking geschiedt in ieder geval door vermelding in het financieel verslag van de politieke partij. Giften van één gever met een gezamenlijk bedrag van $4.537,8$ o euro of meer per jaar worden beschouwd als één gift. Bij de openbaarmaking moeten de hoogte van het bedrag, de datum waarop de gift is gedaan en de naam van de gever worden vermeld. Indien de gever bezwaar heeft gemaakt tegen vermelding van zijn naam, kan vermelding ervan achterwege blijven, maar dan moet wel een omschrijving worden gegeven van de categorie van instellingen of organisaties waartoe hij behoort. In het financieel verslag van een politieke partij wordt ook het totaal aan giften vermeld.

\subsection{De praktijk}

Het is niet eenvoudig een beeld te krijgen van de praktijkvan financieringvan politieke partijen. Weliswaar moeten de partijen die overheidssubsidie ontvangen jaarlijks een door een accountant gecontroleerde jaarrekening aan de overheid toesturen, maar zij hoeven die jaarrekeningen niet openbaar te maken en de overheid doet dat ook niet. Geïnteresseerden moeten zich dus tot de politieke partijen wenden, dan wel tot de minister met een beroep op de Wet openbaarheid van bestuur. ${ }^{223}$ De bedragen van de aan politieke partijen verstrekte overheidssubsidies zijn wel openbaar. ${ }^{224}$ De websites van de politieke partijen verschillen onderling sterk in de mate van openheid over de financieringsbronnen. ${ }^{225}$

Beschikt men overigens over de jaarrekeningen van een politieke partij, dan moet men zich niet teveel voorstellen van de informatie die daarin wordt verstrekt. Het

220 Artikel 6.2 Mediawet.

22I Artikel I8 Wspp.

222 Tenzij men zich niet heeft laten registreren en dus geen aanduiding van de partijnaam mag vermelden boven de kandidatenlijst op het stembiljet, maar dat komt in de praktijk nauwelijks voor.

223 Waarna deze eerst weer de partijen consulteert, met het oog op eventuele privacygevoelige gegevens. Bij de toepassing van de Wet openbaarheid van bestuur geldt het adagium 'eens openbaar altijd openbaar'. Doordat iemand kennelijk daarnaar een keer gevraagd heeft, zijn nu de jaarrekeningen van de meeste politieke partijen van het jaar 2006 op de website van de rijksoverheid terug zijn te vinden, zie: www.rijksoverheid.nl/documenten-en-publicaties/wob-verzoeken/2008/Io/2I/inzage-in-subsidieverantwoordingen-2007-van-alle-politieke-partijen.html.

224 Artikel I7 Wspp.

225 Anno 2010 lijkt de Partij van de Arbeid de meeste openheid van zaken te geven. Deze partij heeft zelfs een eigen regeling voor de openbaarheid van ontvangen giften. Boven de 500 euro worden de naam en de hoogte van het bedrag op de website en in de jaarrekening gepubliceerd. Zie www. pvda.nl. 
betreft een standaard balans met daarop de activa en passiva. Indien de partij subsidie van de overheid krijgt, moet deze balans zijn opgemaakt volgens een bepaald model. ${ }^{226}$ De partijen die overheidssubsidie genieten, lijken aan deze eis te voldoen en bovendien aan de plicht tot openbaarmaking van giften vanaf het in de wet genoemde bedrag. Interessant is voorts te zien dat de meeste partijen nog steeds het merendeel van hun inkomsten genereren uit contributiegelden. Goede tweede is echter de overheidssubsidie. Uit de jaarrekeningen die zijn onderzocht voor dit preadvies, blijkt verder dat de gifteninkomsten over het algemeen relatief bescheiden zijn. ${ }^{227}$

De financiering van de recent opgekomen politieke partijen zoals de Lijst Pim Fortuyn, Trots op Nederland ${ }^{228}$ en de Partij voor de Vrijheid, is het minst transparant. Geen van deze partijen ontving overheidssubsidie en aan de verslagverplichtingen die daarmee samenhangen, hoefden en hoeven zij dus niet te voldoen. Alleen de bepaling over de openbaarheid van giften is op hen van toepassing. Of zij daaraan hebben voldaan, valt uit openbare gegevens niet af te leiden. Het burgerlijk recht draagt bij een partij als de PVV, met één bestuurslid, tevens enig partijlid, ook niet bij aan het in bredere kring bekend worden van de jaarstukken der vereniging. In feite zijn we hier aangewezen op de onderzoeksjournalistiek. Zo berichtte de Volkskrant medio 2009 dat Wilders naast de politieke vereniging tevens een 'Stichting Vrienden van de PVV' heeft opgericht, die niet alleen partijkosten financiert, maar die tevens de kosten betaalt voor de juridische procedures waarin hij is verwikkeld. Volgens het bericht zou Wilders minstens roo.00o euro in de Verenigde Staten van Amerika hebben ingezameld, afkomstig van anti-jihadsympathisanten. ${ }^{229}$

Grote schandalen rond private financiering van politieke partijen hebben zich in Nederland nauwelijks voorgedaan..$^{20}$ Het enige bekende schandaal naar aanleiding van giften van particulieren is nog steeds de zogeheten 'lintjesaffaire' uit I909. ${ }^{23 \mathrm{I}}$ Affaires met giften van bedrijven of maatschappelijke organisaties kwamen vaker voor, maar ook hier lijkt eerder sprake te zijn geweest van incidenten dan van structurele patronen, al kunnen we dat door het gebrek aan openheid van de partijen niet met zekerheid zeggen. In de literatuur wordt het geringe aantal affaires verklaard uit het feit dat het ten tijde van de verzuiling aanvaardbaar werd geacht om giften te

226 Artikel 5 Regeling subsidiëring politieke partijen.

227 Er is gebruik gemaakt van de informatie afkomstig van de websites van de politieke partijen die zitting hebben in het parlement (Eerste en Tweede Kamer) en de informatie van het ministerie van Binnenlandse Zaken en Koninkrijksrelaties.

228 Over de financiering van Trots op Nederland zie Elsevier, Favorita houdt financiers Verdonk buiten beeld, I9 maart 2008.

229 De Volkskrant, Financiering onduidelijk, I9 juni 2009. Zie tevens een uitgebreid artikel over dit onderwerp: Vrij Nederland, 'Wie betalen Wilders', november 2009, alsmede Dragstra 2008, p. 338.

230 Zie voor deze conclusie o.a. Dragstra 2008, p. 332 e.v., waar hij ook een overzicht geeft van alle bekende affaires. Daaraan is hierna het nodige ontleend.

23I De voorman van de Antirevolutionaire Partij en destijds minister van Binnenlandse Zaken Abraham Kuyper had in I903 een Amsterdamse zakenman voorgedragen voor een Koninklijke onderscheiding. Niet lang daarna had de zakenman via Kuyper aanzienlijke bedragen aan de kas van de partij geschonken. Zie uitvoerig over deze affaire: De Bruijn 2005. 
ontvangen van bedrijven en andere organisaties binnen de eigen zuil, zoals kerken en vakbonden. ${ }^{232}$ Met de ontzuiling nam misschien de tolerantie daarvoor af, maar dat gold ook voor de bereidheid van het bedrijfsleven en van andere organisaties om geld aan politieke partijen te doneren. Zij hadden voldoende andere mogelijkheden om invloed uit te oefenen op de politiek, bijvoorbeeld door rechtstreekse contacten met ministeries. ${ }^{233}$ Toch zijn er in het recente verleden wel enige incidenten, of zo men wil schandalen, op het gebied van de partijfinanciering geweest, vooral rond de opkomst van de Lijst Pim Fortuyn. Zo gingen er geruchten dat bepaalde kandidaat-Kamerleden in ruil voor een royale bijdrage een verkiesbare plaats op de kandidatenlijst hadden gekregen. Wegens gebrek aan bewijs is het Openbaar Ministerie echter niet tot vervolging overgegaan.

Naast contributies, subsidies en giften, ontvangen de meeste partijen ook zogenoemde afdrachten van de tot hun partij behorende bestuurders en volksvertegenwoordigers. Daarop zijn we in paragraaf 3 al ingegaan. Deze afdrachten behoeven niet openbaar gemaakt te worden, omdat ze van natuurlijke personen afkomstig zijn.

\subsection{Wetgeving in ontwikkeling}

Vanuit de Raad van Europa is Nederland aangespoord om tot nieuwe regelgeving te komen voor de partijfinanciering. De Raad richtte in 1999 de zogeheten GRECOgroup (Groups of States against Corruption) op met als doel het bestrijden van corruptie binnen de lidstaten. Bij de groep zijn 47 Europese staten aangesloten, waaronder Nederland en België, alsmede de Verenigde Staten van Amerika. Zij onderwerpen zich vrijwillig aan evaluaties van anti-corruptiemaatregelen die worden uitgevoerd door expertteams van collega-lidstaten. Sinds 2007 worden evaluaties uitgevoerd van de regels over de transparantie van partijfinanciering nadat de Venice Commission van de Raad van Europa had aangegeven dat een gebrekkige regulering op dit terrein aanleiding kan zijn voor ongewenste beïnvloeding van het politieke proces. ${ }^{234}$ Eind 2007 heeft een GRECO-expertteam de Nederlandse regels over transparantie van partijfinanciering geëvalueerd. Medio 2008 werd het eindrapport van deze evaluatie geaccordeerd door de algemene vergadering van GRECO. Het eindrapport bevat maar liefst dertien aanbevelingen om tot verbeteringen te komen. Het algemene oordeel was dat het huidige wettelijk kader in Nederland geen waarborgen biedt dat het electoraat voldoende toegang heeft tot informatie over de financiële belangen van politieke partijen en dat er onvoldoende toezicht wordt gehouden. Samengevat in zeven punten komen de GRECO-aanbevelingen, die overigens niet bindend zijn, op het volgende neer: (I) het invoeren van een algemene

232 Dragstra 2008, p. 333 en Koole 1992, p. 195.

233 Aldus Koole I992, p. I97 en Jansen, 'Van staatskas naar partijkas. Directe subsidiëring politieke partijen: een taboe doorbroken', Elsevier 3 augustus I99I, p. 20-22, die zich afvraagt of bedrijven eigenlijk wel geld aan politieke partijen willen geven.

234 Venice Commission 2001. 
rapportageplicht van partijen en groeperingen in het Nederlandse parlement over hun financiële situatie en het verplichten van het indienen van een financieel jaarverslag; (2) het openbaar maken van schenkingen en legaten van zowel rechtspersonen als natuurlijke personen, inclusief partijleden, en het verlagen van de daarvoor geldende drempel van 4.537,80 euro naar een geschikt niveau; (3) het treffen van voorzieningen voor de inzichtelijkheid van de financiering van regionale en lokale partijen; (4) het tevens onder de wet brengen van direct of indirect met een partij verbonden instanties; (5) het instellen van onafhankelijk toezicht op de financiering van politieke partijen en van de verkiezingscampagnes door een orgaan dat daartoe beschikt over voldoende financiële en personele middelen; (6) het geven van duidelijke definities van overtredingen van regels inzake de financiering van politieke partijen en het invoeren van effectieve, evenwichtige en afschrikwekkende sancties bij overtreding van de regels, waaronder administratieve sancties voor minder ernstige overtredingen; en ten slotte (7) het aanbieden van advies en training over de toepasselijke regels aan politieke partijen en aan verkiezingskandidaten

Ten tijde van de GRECO-evaluatie had de Nederlandse regering het onderwerp van transparantie van partijfinanciering reeds ter hand genomen door het opstellen van een voorstel voor een Wet financiën politieke partijen (WFPP). Al in september 2006 had de Raad van State over dit wetsvoorstel advies uitgebracht. Ondanks of, waarschijnlijker, dankzij de aanbevelingen van GRECO is het voorstel echter nog niet bij de Tweede Kamer ingediend. Daardoor is de tekst ervan nog niet openbaar. Over de richting waarin de regering denkt, valt echter wel iets te zeggen aan de hand van andere bronnen, zoals krantenberichten, een advies dat de Kiesraad ${ }^{235}$ heeft uitgebracht over een concepttekst en dat wel openbaar is, en het onlangs door GRECO gepubliceerde compliance report, waarin is bezien welke maatregelen Nederland heeft getroffen na het kritische evaluatierapport uit 2008. Uit deze stukken kan worden afgeleid dat de regering overweegt om giften vanaf 750 euro, ook van natuurlijke personen en ook giften in natura, verplicht te laten registreren en om deze openbaar te laten maken bij bedragen van meer dan 4.500 euro (aanvankelijk 3.000 euro). Bovendien wordt een limiet vermeld van 25.000 euro jaarlijks per donateur. Verder wordt overwogen om het toezicht op de naleving van de wet op te dragen aan de Kiesraad. Ook nieuwe politieke partijen zullen onder bepaalde voorwaarden financiële gegevens openbaar moeten maken. Wat opvalt, is dat de nieuwe regels vermoedelijk alleen zullen gelden voor partijen die deelnemen aan de landelijke verkiezingen. Dat betekent dat, anders dan GRECO adviseerde, lokale en regionale partijen niet onder het nieuwe wettelijke regime zullen vallen. De Kiesraad stemt daarmee in: volgens de raad zijn het nieuwe openbaarmakingsregime en het toezicht daarop van zodanige aard, dat het beste eerst ervaring kan worden opgedaan met deze beperkte reikwijdte. Uit het compliance report van GRECO kan worden afgeleid dat de Nederlandse regering bij dit standpunt blijft.

235 De Kiesraad is een onafhankelijk orgaan van de rijksoverheid dat vanouds fungeert als nationaal stembureau en dat daarnaast de regering adviseert over vraagstukken rond Kieswet en verkiezingen. 
Aanvankelijk zou de Kiesraad alleen bevoegd worden om de jaarrekeningen van politieke partijen te controleren. Indien hij een overtreding zou vermoeden, zou het Openbaar Ministerie moeten beoordelen of strafrechtelijke vervolging aangewezen is. De Kiesraad meende dat het opleggen van een administratieve boete eveneens tot de mogelijkheden zou moeten behoren. Uit het compliance report van GRECO kan worden afgeleid dat de Nederlandse regering inmiddels dit standpunt deelt. Van het opleggen van administratieve boetes wordt nu zelfs meer heil verwacht dan van de strafrechtelijke weg. Slechts in uitzonderingsgevallen zou nog strafrechtelijke vervolging dienen plaats te vinden. Kennelijk heeft de Nederlandse regering het advies van GRECO in dezen opgevolgd.

De nieuwe regering en de nieuwe Kamers zullen uiteindelijk moeten beslissen hoe de nieuwe regelgeving er zal gaan uitzien. De huidige regering heeft toegezegd dat eind 20II wederom aan GRECO zal worden gerapporteerd over de geboekte voortgang.

\subsection{Is aanpassing van de wetgeving wenselijk?}

\subsubsection{De wetgeving over giften aan partijen}

Het antwoord van de regering op de vraag of over dit onderwerp meer geregeld moet worden, luidt kennelijk: ja. Daarmee zijn wij het eens, maar de interessantste vraag is natuurlijk hoe ver deze wetgeving zal moeten gaan en waarom. Een wettelijke regeling kan meer of minder verstrekkend zijn. Ze kan alleen betrekking hebben op transparantie van giften, waarbij de nodige keuzen gemaakt moeten worden over de hoogte van de te hanteren ondergrens en over waarborgen voor de privacy van de gevers. Ze kan daarnaast ook limieten stellen aan de hoogte of de herkomst van giften, zoals in veel landen gebruikelijk is.

Als er financiële banden zijn tussen een partij en organisaties of personen die concrete belangen kunnen hebben bij de inhoud van te nemen politieke beslissingen, dan moeten de kiezers dat in onze ogen zonder veel inspanning te weten kunnen komen. Men zou kunnen redeneren dat de kiezer het enkele feit dát een partij daarover geen openheid geeft, wel kan meewegen in zijn beslissing over de uit te brengen stem, en dat regels hierover dus helemaal niet nodig zijn, maar dat is ons wat te gemakkelijk. Wie liberaal denkt, wil natuurlijk niet ineens socialistisch stemmen, alleen maar omdat de eerste stroming geen en de tweede wel openheid lijkt te bieden over de financiering. Een waarborg tegen slechts schijnbare openheid heeft hij evenmin als daarop geen toezicht bestaat. Enige regelgeving om transparantie te waarborgen en ook toezicht op de naleving daarvan lijkt in beginsel dus wel gewenst. Een beperking tot de partijen die enige kans maken op daadwerkelijke politieke invloed, zoals in de huidige wetgeving, is aanvaardbaar en waarschijnlijk ook onvermijdelijk. Wel zullen de regels uiteindelijk tevens, misschien wel juist ook, moeten gelden voor partijen die alleen lokaal of regionaal actief zijn. Een beperking tot giften boven een bepaald bedrag is uit het oogpunt van transparantie ook aanvaardbaar, omdat het uit de aard der zaak gaat om de in het oog springende 
uitschieters. Of de voorgestelde drempels uit dat oogpunt voldoen, kunnen wij niet goed beoordelen, maar met GRECO en de regering zijn wij het wel eens dat de huidige wetgeving en praktijk onvoldoende openheid en controle garandeert, terwijl de afhankelijkheid van giften in de toekomst eerder zal toenemen dan afnemen. Ook flinke giften van particulieren zouden geregistreerd moeten worden en in beginsel tevens openbaar gemaakt, al realiseren wij ons dat het waarborgen van de privacy daarbij een lastig op te lossen probleem kan vormen. ${ }^{236}$ Andere lastige vragen voor de wetgever betreffen de opgave om ongewenste neveneffecten en ontduikingsmogelijkheden te voorkomen. Als ook bonafide donateurs door de nieuwe regels worden afgeschrikt, dan is niemand daarmee gediend. Wettelijke regels over openbaarheid van financiële bijdragen aan partijen, kunnen bovendien tot gevolg hebben dat juist de minder bonafide donateurs overgaan op giften in natura of de minder bonafide politici op het werven van fondsen voor hen persoonlijk. De organisatie die met het toezicht wordt belast, zal ook daarop zicht moeten kunnen krijgen. De ervaringen in andere landen leren overigens al dat een sluitend systeem niet goed mogelijk lijkt. ${ }^{237}$

Een heel andere vraag is, of er ook een limiet moet worden gesteld aan de hoogte van giften. Het stellen van een dergelijke limiet gaat verder dan alleen het doel openheid te waarborgen. Het dient de gelijkheid van kansen tussen partijen onderling. ${ }^{238}$ Financiële middelen zijn immers niet gelijkelijk over de bevolking verspreid en sommige politieke partijen hebben nu eenmaal een rijkere achterban dan andere. Veel landen kennen daarom een regeling op dit punt. Sommige landen hebben zelfs gekozen voor het geheel verbieden van giften aan politieke partijen, zoals Frankrijk en Canada, maar de meeste landen stellen bepaalde grenzen aan de hoogte van donaties. ${ }^{239}$ Dat laatste geldt zelfs voor de Verenigde Staten van Amerika, waar het geven van geld aan een politieke partij valt onder de grondwettelijke bescherming van het recht op vrijheid van meningsuiting, een recht dat in de VS slechts onder zware voorwaarden mag worden beperkt..$^{20}$ Een reden voor beperking wordt daar gezien in de gedachte dat politieke partijen op een gelijkwaardige wijze over financiële middelen moeten kunnen beschikken (level playing field). In Duitsland komt men deze gedachte eveneens tegen in het uitgangspunt van Chancengleichheit. In Nederland trekt dit aspect van de partijfinanciering tot nu toe veel minder aandacht dan dat van de transparantie. Misschien komt dit doordat het wel meevalt met de ongelijkwaardigheid in posities van partijen op dit punt, maar misschien komt het ook doordat we daar, door het gebrek aan openheid, alleen maar geen weet van hebben. Logisch gezien moet de wetgeving daarom beginnen met regels over registratie en openbaarheid. Misschien zou de wetgever zich daar voorlopig maar toe

236 Koole 2008 , p. 47.

237 Zie daartoe de overige evaluatierapporten van GRECO op http://www.coe.int/t/dghl/monitoring/greco/default_en.asp.

238 Koole, 2008 , p. 47 e.v.

239 Koole 2008, p. 48.

240 US Supreme Court, 30 januari I976, 424 U.S. I, Buckley v. Valeo, http://www.law.cornell.edu/ supct/html/historics/USSC_CR_0424_oooI_ZS.html. 
moeten beperken. Zoals we zagen is dat waarschijnlijk al ingewikkeld genoeg. Als die wetgeving effect heeft, valt vanzelf meer te zeggen over de vraag of in Nederland ook het waarborgen van een gelijkwaardig speelveld een opgave voor de wetgever is.

\subsubsection{De subsidieregels}

Ook wat de subsidiëring van politieke partijen betreft, staan er enkele vragen op de agenda. Ten eerste de vraag of daaraan überhaupt niet een eind moet worden gemaakt, zoals de Partij voor de Vrijheid (PVV) wil. Die partij vindt dat subsidiëring de overheid ongewenste invloed geeft op de organisatie en het functioneren van partijen. Partijen kunnen best zonder subsidie functioneren, waarvan zij zelf het bewijs levert. ${ }^{24}$ Het PVV-voorstel klinkt aantrekkelijk in het licht van de verenigingsvrijheid en ook omdat subsidiëring onvermijdelijk leidt tot bevoordeling van gevestigde partijen boven nieuwkomers, maar het lijkt een onbegaanbare weg. Een keuze voor afschaffing van subsidies zal partijen weliswaar kunnen aanzetten om meer energie te steken in de ledenwerving, maar het is de vraag of dit ook veel nieuwe leden zou opleveren De afname van ledenaantallen zien we immers niet alleen bij politieke partijen en de oorzaken ervan lijken te liggen in algemene maatschappelijke ontwikkelingen die niet vallen te beïnvloeden. Per saldo zou het afschaffen van subsidies de partijen dus afhankelijker maken van donaties. Dat zou een extra druk zetten op de wetgeving daarover en op het toezicht daarop. Vermindering van overheidsbemoeienis mag er daarom niet van worden verwacht. ${ }^{242}$ De bereidheid om geld te doneren, zal er evenmin door toenemen, waardoor veel politieke partijen in financiële nood kunnen komen. De relatief nadelige positie van nieuwe partijen zou er wel door worden beëindigd en zelfs worden omgekeerd, omdat het onvermijdelijk is dat de financieringsregels aanknopen bij het behalen van zetels of op zijn vroegst bij het stellen van kandidaten voor verkiezingen.

Een tweede vraag is of het nog wel verdedigbaar is dat alleen partijen met ten minste duizend leden in aanmerking komen voor subsidiëring. Het is een wat rare eis in het systeem van de Wet subsidiëring politieke partijen, die voor het overige uitgaat van het aantal verworven zetels in het parlement en dus van het behaalde verkiezingssucces. Nieuwe partijen hebben tegenwoordig bovendien meer en vooral ook heel andere mogelijkheden dan vroeger om zich een aanhang te verwerven, ook zonder daarbij te vervallen in de door de wetgever gevreesde 'lege huls' die alleen ten dienste van de parlementsfracties staat. Ondanks onze voorkeur voor de klassieke ledenpartij, ${ }^{243}$ menen wij dat de wetgever hier geen taak heeft en dat de ledeneis daarom zou moeten vervallen. Iets heel anders is, dat het aantal leden uiteraard wel een criterium kan zijn bij het subsidiëren van activiteiten die nu eenmaal duurder

24 I O.a. Kamerstukken II 2009-20Io, 3I 906, nr. 6, p. I-2.

242 De jurisprudentie van het Europees Hof voor de rechten van de mens staat overigens ook toe dat een lidstaat door middel van financieringsregels ingrijpt in de verenigingsvrijheid van politieke partijen Zie vooral EHRM 7 september 2007, Parti Nationaliste Basque - Organisation Régionale D'Iparralde v. France, EHRC 2007, 87, m.nt. Ph. Kiiver.

243 Zie daarover paragraaf 4.4.I. 
uitvallen naarmate een partij meer leden heeft. Aan de oplossing die de Raad voor het openbaar bestuur voorstelt - het meetellen van donateurs bij het vaststellen van de aanspraak op subsidie en het tegelijkertijd waarborgen dat die donateurs dan nagenoeg dezelfde rechten krijgen als partijleden ${ }^{244}$ - heeft waarschijnlijk niemand behoefte. Ze maakt de zaken ook onnodig ingewikkeld.

De derde vraag is of ook lokale en regionale partijen in aanmerking zouden moeten komen voor subsidie. De regering schatte in 2006 dat er ongeveer 700 politieke partijen in Nederland uitsluitend actief zijn in een bepaalde gemeente of regio en dus op zijn hoogst zetels verwerven in de gemeentelijke of provinciale volksvertegenwoordiging. ${ }^{25}$ Van de bijna tienduizend gemeentelijke volksvertegenwoordigers in Nederland was op dat moment een kwart afkomstig van een lokaal georganiseerde partij. In veel gemeenten maken lokaal georganiseerde partijen tevens deel uit van het bestuurscollege. Begin 2006 was een op de vier gemeentelijke bestuurders, burgemeesters niet meegerekend, afkomstig uit een lokaal georganiseerde partij. Lokale partijorganisaties die onderdeel zijn van een landelijke partij, ontlenen voordelen aan de algemene financiële situatie van hun partij die meestal gunstig beïnvloed wordt door partijsubsidies. Het is begrijpelijk dat dit lokale partijen steekt. ${ }^{246}$ De nationale regering heeft altijd het standpunt ingenomen dat het niet op haar terrein ligt om hieraan desgewenst iets te doen, maar dat dit het terrein is van de gemeentelijke en provinciale overheden. ${ }^{247}$ Als men zich voorstelt hoe dat zou kunnen gaan, lijkt dit een wat lastig standpunt. Ofwel de lokale partijen zijn lokaal in de minderheid en dan zal het lokale bestuur niet zo snel beslissen dat er een subsidieregeling moet komen teneinde de levendigheid van de lokale democratie in algemene zin te bevorderen. Ofwel de lokale partijen (of één enkele lokale partij) hebben een meerderheid in de lokale volksvertegenwoordiging, maar dan krijgt het invoeren van een op henzelf gerichte subsidieregeling uit de algemene belastingmiddelen een wat onfris karakter. Voor zover wij weten is dit tot nu toe trouwens nergens gebeurd. Het regeringsstandpunt komt er dus in de praktijk op neer dat men vrede heeft met de huidige situatie en misschien kan het ook wel niet anders. Hoewel het uit principieel oogpunt sympathiek zou zijn, lijkt een uitvoerbare subsidieregeling die het omvangrijke en bovendien zeer beweeglijke veld van de lokale partijen in haar reikwijdte betrekt, niet goed voorstelbaar.

\footnotetext{
244 Raad voor het openbaar bestuur 2009.

245 Kamerstukken II 2005-2006, 29 869, nr. I7, p. 2.

246 Overigens kunnen lokale partijen wel aanspraak maken op tegemoetkomingen voor fractieondersteuning. Een recente subsidieregelingvoor devormingvan lokalevolksvertegenwoordigers was op aandringen van de Tweede Kamer eveneens op hen van toepassing. Zie Kamerstukken II 2008-2009, 3I 700 VII, nr. 74.

247 Kamerstukken II 2005-2006, 29 869, nr. I7, p. 2-3.
} 


\section{$7 \quad$ De constitutionele positie van Europese politieke partijen}

\section{I Inleiding}

Europese politieke partijen (hierna ook aangeduid als Europartijen) hebben een opvallende plaats gekregen in de Europese regelgeving. In het Verdrag van Lissabon $^{248}$ treft men ze al aan in artikel Io. Het vierde lid daarvan luidt:

'De politieke partijen op Europees niveau dragen bij tot de vorming van een Europees politiek bewustzijn en tot de uiting van de wil van de burgers van de Unie.'

Daarnaast draagt artikel 224 van het verdrag aan het Europees Parlement en de Europese Raad op een statuut voor de Europese politieke partijen vast te stellen. Ten slotte wordt in artikel I2, tweede lid, van het Handvest van de grondrechten van de Europese Unie geproclameerd dat de politieke partijen op Europees niveau bijdragen aan de uiting van de politieke wil van de burgers van de Unie. De Europese wetgever besteedt dus nadrukkelijk aandacht aan politieke partijen. Ondanks deze aandacht lijken de Europartijen in de praktijk nog niet goed in staat uitdrukking te geven aan de politieke (Europese) wil van burgers. ${ }^{249}$ Eén van de oorzaken daarvan is waarschijnlijk het politieke bestel van de Europese Unie, dat sterk afwijkt van dat van de lidstaten: er is in de Europese Unie geen regering die steunt op een parlementaire meerderheid van een bepaalde politieke signatuur. ${ }^{250}$ Europese politieke partijen hebben dan ook een nogal andere positie binnen de Europese Unie dan de nationale partijen binnen de afzonderlijke lidstaten. Bovendien zijn zij, ondanks recente wijzigingen in hun financiële positie, nog steeds voor een groot deel afhankelijk van de nationale politieke partijen.

Bij de huidige Europartij moet men zich overigens niet een homogene organisatie voorstellen. Zij bestaat uit een netwerk van drie structuren: (I) de nationale politieke partijen van de lidstaten, die de verbinding vormen met de politieke familie van verwante partijen in alle lidstaten samen; (2) de Eurofractie, de 'officiële vertegenwoordiger' van de Europese partijfamilie in het Europees parlement; en (3) de transnationale, buitenparlementaire partijorganisatie, de overkoepelende organisatie van de politieke partijen (van dezelfde familie) uit de lidstaten en de Eurofractie.

\subsection{Ontwikkeling van de Europartijen}

Aan het begin van het Europese integratieproces in het midden van de vorige eeuw was er nog geen sprake van Europese politieke partijen. Naarmate het proces van Europese integratie zich verbreedde, werd ook de samenwerking tussen verwante

248 Verdrag van Lissabon tot wijziging van het Verdrag betreffende de Europese Unie en het Verdrag tot oprichting van de Europese Gemeenschap, C 306, I7 december 2007.

249 Vgl. Voerman 2009, p. 216.

250 Vgl. Voerman, 2009, p. 2I6. Zie ook Zotti 20Io, hfd. 5, p. 89-I07. 
politieke partijen in de deelnemende lidstaten intensiever. Dit zou uiteindelijk leiden tot wat wij nu typeren als de Europese politieke partij.

Het Europese integratieproces nam een aanvang met het in 1952 in werking getreden verdrag tot oprichting van de Europese Gemeenschap voor Kolen en Staal (EGKS). ${ }^{251}$ Voor de controle van de Hoge Autoriteit van de EGKS werd een Gemeenschappelijke Vergadering geïnstitutionaliseerd die bestond uit afgevaardigden van de parlementen van de zes deelnemende landen. ${ }^{252}$ In de praktijk bleek dat deze afgevaardigden zich niet zozeer op nationaliteit maar op politieke kleur gingen groeperen. ${ }^{253} \mathrm{Na}$ de totstandkoming van de Verdragen van Rome in 1957 waarin de Europese Economische Gemeenschap (EEG) en de Europese Gemeenschap voor Atoomenergie (Euratom) werden geregeld, ${ }^{254}$ werd de Gemeenschappelijke Vergadering omgedoopt tot Europees Parlement. ${ }^{255} \mathrm{Al}$ snel bleek dat zowel de sociaaldemocraten als de communisten zich sterk Europees organiseerden. ${ }^{256}$ De sociaaldemocraten vormden de 'Socialistische Fractie' met een zelfstandig coördinerend bureau en een permanent secretariaat. De Nederlandse Partij van de Arbeid had in dit proces een voortrekkersrol. ${ }^{257}$ Andere partijen volgden het voorbeeld van de sociaaldemocraten waardoor aan het eind van de jaren zestig en het begin van de jaren zeventig van de vorige eeuw gesproken kan worden van het ontstaan van Europese fracties. Hoewel men binnen de fracties trachtte om ook bij het stemgedrag gezamenlijk op te trekken, kwam daar in de praktijk aanvankelijk weinig van terecht: de nationale partijen leverden niets van hun macht in..$^{25}$

De eerste aanzet voor de ontwikkeling van Europartijen ligt dus in het ontstaan van parlementaire fracties waarin nationale afgevaardigden zaten van dezelfde politieke familie. Aan het eind van de jaren zestig van de vorige eeuw groeide het besef dat deze ontwikkeling verder moest worden gestimuleerd en in I974 werd tijdens een Europese top in Parijs besloten om het Europees Parlement in de toekomst rechtstreeks te laten kiezen door de burgers van de lidstaten. Dit besluit gaf een sterke stimulans om de tot dan toe nog losse verbanden tussen de nationale partijorganisaties te intensiveren en tot een hechtere samenwerking te komen. Sindsdien werd gesproken van (Euro)federaties, de voorlopers van de huidige Europartijen. Het ging daarbij om samenwerkingsverbanden zowel binnen als buiten de Eurofractie tussen politieke partijen van de lidstaten met eenzelfde politiek signatuur. Doel van de federaties was om gezamenlijk de kiezers te mobiliseren en om als directe schakel te gaan fungeren tussen het Europese electoraat en de Europese instellingen,

25I Zie meer over het Verdrag inzake de EGKS: http://europa.eu/legislation_summaries/institutional_affairs/treaties/treaties_ecsc_nl.htm.

252 Duitsland, Frankrijk, Italië, België, Luxemburg en Nederland.

253 Zie Zotti 20Io, p. 28 en ook Voerman 2009, p. I94.

254 Zie hierover meer: http://europa.eu/legislation_summaries/institutional_affairs/treaties/treaties_eec_nl.htm.

255 De drie Europese entiteiten (EGKS, EEG en Euratom) werden vanaf 1967 met de overkoepelende naam Europese Gemeenschappen aangeduid.

256 Zie Voerman 2009, p. 194.

257 Van Rooyen \& Voerman 2008, p. I47.

258 Aldus Voerman 2009, p. 195 . 
maar in de praktijk bleek dat de rol van de nationale partijen dominant bleef bij het Europees integratieproces en binnen de diverse federaties. Dit werd voornamelijk veroorzaakt doordat er grote politieke verschillen bestonden tussen de politieke partijen van de nationale lidstaten van eenzelfde signatuur. ${ }^{259}$ De verkiezingen voor het Europees Parlement werden daarom in de literatuur wel aangeduid als second order elections: verkiezingen die zich afspeelden binnen een nationale context en die werden gekarakteriseerd door electorale verliezen voor regeringspartijen en electorale kansen voor kleinere en nieuwe partijen, gepaard gaande met een lage opkomst van kiezers. ${ }^{260}$ De directe verkiezing van de leden van het Europees Parlement leidde dus niet tot de opkomst van sterke Europese politieke partijen. De verschillen tussen de nationale partijen van dezelfde politieke families bleken daarvoor te groot.

Pas aan het eind van de jaren tachtig van de vorige eeuw brak een nieuwe periode aan voor de ontwikkeling van de (toen nog) Europese federaties. De ondergang van het communisme in Oost-Europa en het toekomstige lidmaatschap van de OostEuropese landen bleek aanleiding voor de federaties om banden aan te knopen met de nieuwe politieke partijen die in de Oost-Europese landen ontstonden. Bovendien werd in diezelfde tijd het proces van Europese integratie versneld. In 1992 werd het Verdrag van Maastricht ${ }^{26 \mathrm{I}}$ ondertekend, een verdrag dat onder andere voorzag in een versterking van de bevoegdheden van het Europees Parlement. Bovendien werd op aandringen van de politieke partijen zelf in dit verdrag een officiële verwijzing opgenomen naar de Europese politieke partij. Gevolg was dat ook de Europese federaties zich gingen versterken en dat zij zich omdoopten tot Europese politieke partijen. Politiek was deze erkenning van grote betekenis, juridisch gezien werd er vooralsnog geen verdere uitwerking aan gegeven. Niettemin nam het zelfvertrouwen van de Europese politieke partijen toe en voor het eerst zou de term Europartij in zwang raken. De Europese politieke partijen gingen zich in de jaren negentig van de vorige eeuw voor het eerst serieus gezamenlijk richten op de beïnvloeding van de Europese politieke agenda, in plaats van zich vooral te concentreren op het opstellen van verkiezingsprogramma's en electorale mobilisatie, zoals zij vanaf 1979 hadden gedaan. ${ }^{262}$ Ook veranderden zij hun interne organisatiestructuur. Een eerste belangrijke hervorming was de institutionalisering van de bijeenkomsten van de nationale partijleiders met de voornaamste geestverwanten binnen de organen van de Europese Unie. Doel van dit overleg was te komen tot een gezamenlijke opstelling in de Europese Raad van staats- en regeringsleiders om zodoende de politieke invloed te vergroten. ${ }^{263}$ Ook het aantal thematische werkgroepen binnen de Europartijen nam toe, gestimuleerd door de toename van het aantal deelnemende politieke partijen vanuit Midden- en Oost Europa. Binnen de (informele) overlegvormen van de politieke partijen van eenzelfde partijfamilie werd veelal afgesproken om de con-

259 Vgl. Ladrech 2002, p. 83. Zie ook uitgebreid Voerman 2009, p. I96-202.

260 Reifen \& Schmitt I980.

26I Officieel het Verdrag betreffende de Europese Unie geheten, Publicatieblad nr. C I9I, 29 juli I992.

262 Hix, I996, p. 312;. Hix \& Lord I997, p. I90; Voerman 2009, p. 209.

263 Moschonas 2004, p. II8-I2I. 
sensusregel in te ruilen voor de meerderheidsregel. ${ }^{264}$ In de praktijk bleek echter dat meestal toch op zoek wordt gegaan naar consensus. ${ }^{265}$

Een hinderpaal voor onafhankelijkheid van de Europartijen bleef intussen het feit dat zij niet beschikten over zelfstandige financiering voor bijvoorbeeld kantoorruimte en personeel. Deze kosten werden voor een groot deel door de verschillende Eurofracties betaald. Dat veranderde met de invoering van het zogeheten partijenstatuut. Dit statuut was gebaseerd op het in 2003 in werking getreden Verdrag van Nice ${ }^{266}$ waarin de bepaling over de Europese politieke partijen zoals vastgelegd in het Verdrag van Maastricht, werd uitgebreid met de opdracht om de Europese politieke partijen nader te regelen, waarbij in het bijzonder regels inzake hun financiering dienden te worden gesteld. ${ }^{267}$ Eind 2003 werden deze regels, het partijenstatuut, in een Europese verordening (nr. 2004/2003) vastgesteld. ${ }^{268}$

\subsection{Regulering}

Verordening 2004/2003 betreffende het statuut en de financiering van politieke partijen op Europees niveau (hierna: de verordening) bestaat uit veertien artikelen waarin voornamelijk de subsidiëring van Europese politieke partijen is geregeld. In artikel 2 van de verordening wordt een politieke partij omschreven als een vereniging van burgers die politieke doeleinden nastreeft en die erkend is door, of opgericht is in overeenstemming met de rechtsorde van ten minste één lidstaat. Daarnaast wordt onder een alliantie van politieke partijen verstaan: een gestructureerde samenwerking tussen minstens twee politieke partijen. Beide omschrijvingen zijn van belang, aangezien het derde lid van artikel 2 van de verordening stelt dat onder een politieke partij op Europees niveau wordt verstaan: een politieke partij of alliantie die voldoet aan de voorwaarden van artikel 3 van de verordening. Deze voorwaarden zijn achtereenvolgens: (a) de partij heeft rechtspersoonlijkheid in de lidstaat waar haar zetel is gevestigd; (b) de partij is in ten minste een kwart van de lidstaten vertegenwoordigd door leden van het Europees Parlement of leden van nationale dan wel regionale parlementen of leden van regionale assemblees of heeft in ten minste een kwart van de lidstaten bij de laatste verkiezingen van het Europees Parlement ten minste drie procent van de in ieder van die lidstaten uitgebrachte stemmen behaald; (c) de partij eerbiedigt in haar programma en optreden de beginselen waarop de Europese Unie is gegrondvest, te weten: vrijheid, democratie, eerbiediging van de mensenrechten en de fundamentele vrijheden alsmede de rechtsstaat; en ten slotte (d) de partij heeft deelgenomen aan de verkiezingen voor het Europees Parlement of heeft haar voornemen daartoe te kennen gegeven. Indien een partij aan deze voorwaarden voldoet, kan zij worden gekwalificeerd als een politieke partij op Europees

264 Vgl. Voerman 2009, p. 203 e.v.

265 Vgl. Voerman 2009, p. 210.

266 Publicatieblad C 80 van Io maart 200I.

267 In de geconsolideerde tekst van het Verdrag betreffende de Europese Unie werd deze bepaling in artikel IgI neergelegd en thans zoals reeds gezegd in artikel ro door de wijzigingen die het Verdrag van Lissabon heeft teweeggebracht.

268 Verordening (EG) nr. 2004/2003, Publicatieblad L 297 van I5 november 2003. 
niveau en kan zij een verzoek doen om financiering uit de algemene begroting van de Europese Unie (artikel 4). Het verzoek tot subsidie wordt ingediend bij het Europees Parlement dat tevens regelmatig controleert of de partijen aan de gestelde voorwaarden voldoen (artikel 5).

Politieke partijen op Europees niveau die op grond van de verordening financiering ontvangen, moeten voldoen aan enkele voorschriften inzake transparantie van hun financieringsbronnen (artikel 6). Zij moeten jaarlijks een staat van ontvangsten en uitgaven en een verklaring van activa en passiva publiceren. Daarnaast moeten zij een verklaring afleggen van hun inkomstenbronnen door overlegging van een lijst van donateurs met opgave per donateur van het geschonken bedrag. Dit voorschrift geldt alleen voor bedragen van 500 euro of meer. Verder mag een partij geen anonieme donaties ontvangen en evenmin donaties uit de begrotingen van de fracties van het Europees Parlement, donaties van ondernemingen waarop de overheid rechtstreeks of onrechtstreeks een overheersende invloed kan uitoefenen, of donaties van meer dan 12.000 euro per jaar per donateur van andere natuurlijke of rechtspersonen. Artikel 6 van de verordening bepaalt uitdrukkelijk dat bijdragen van nationale politieke partijen die lid zijn van een politieke partij op Europees niveau, wel zijn toegestaan. Dit bedrag mag echter niet hoger zij dan veertig procent van de jaarlijkse begroting van die partij. Het geld dat politieke partijen op Europees niveau ontvangen uit de algemene begroting van de Europese Unie of uit enige andere bron, mag niet worden gebruikt voor rechtstreekse of zijdelingse financiering van andere politieke partijen, met name niet van nationale partijen, waarop nationale regelgevingen van toepassing moeten blijven (artikel 7). Aanvankelijk mochten de ontvangen gelden uitsluitend worden gebruikt voor administratieve kosten, kosten in verband met logistieke steun, bijeenkomsten, onderzoek, grensoverschrijdende evenementen, studies, voorlichting en publicaties (artikel 8). In 2007 is dit uitgebreid en is uitdrukkelijk bepaald dat de subsidies tevens mochten worden aangewend voor de financiering van de campagne voor de Europese verkiezingen. Toekenning van deze gelden aan de nationale politieke partijen of kandidaten voor dit doel is echter niet toegestaan. In 2007 is nog een aantal andere wijzigingen in de verordening aangebracht. ${ }^{269}$ De belangrijkste daarvan is, dat ook politieke Europese stichtingen (gelieerd aan een politieke partij op Europees niveau) voor financiële steun in aanmerking kunnen komen (totaal 5 miljoen euro). Doel van deze stichtingen moet zijn het debat over Europa te bevorderen en burgers erbij te betrekken. De grote Europartijen hebben inmiddels alle een dergelijke stichting opgericht die veelal bestaat uit een netwerk van de wetenschappelijke bureaus van de nationale politieke partijen van de lidstaten. ${ }^{270}$ In 2006 ontvingen tien Europartijen in totaal 8,5 miljoen euro subsidie. Twee jaar later was dat Io, 6 miljoen euro..$^{271}$

269 Zie hierover uitvoerig Zotti 20Io, p. 8I. In de Verordeningen I524/2007 en I525/2007 zijn deze wijzigingen opgenomen.

270 Vgl. Voerman 2009, p. 2 I2.

27 I Vgl. Voerman 2009, p. 2 I2. 


\subsection{Praktijk}

De verordening heeft tot nu toe twee belangrijke effecten gehad. In de eerste plaats zijn de politieke partijen op Europees niveau niet langer financieel afhankelijk van de fracties van het Europees Parlement. De kantoren van grote Europartijen zoals de Partij van de Europese Socialisten (PES), de Europese Liberale, Democratische en Reformpartij (ELDR) en de Europese Partij voor de Groenen (EGP) verhuisden daarop ook naar locaties buiten het parlementsgebouw. ${ }^{272}$ In de tweede plaats ontstonden er naast de vier al bestaande politieke partijen op Europees niveau, vijf nieuwe. Vier daarvan met een Eurosceptische signatuur: de Party of the European Left, de Alliance of Independent Democrats in Europe, de EUdemocrats en de Alliance for Europe of the Nations. De eveneens nieuw opgerichte European Democratic Party was de enige nieuwe Europartij die de Europese integratie omhelsde. ${ }^{273}$ In totaal zijn er nu dus negen Europartijen. De praktijk laat overigens zien dat het rechtstreeks lid worden van een van deze Europartijen vaak lastig of zelfs onmogelijk is. Voor zover de mogelijkheid daartoe wel bestaat, lijkt de animo ervoor niet groot. ${ }^{274}$

Van een grotere transparantie lijkt van de kant van de politieke partijen op Europees niveau nog geen sprake te zijn, althans niet voor de kiezer. Een ronde langs de websites van de Europartijen laat zien dat een aantal daarvan wel een korte financiële jaarrekening publiceert, maar dat gegevens over de personen of instellingen die achter de opgegeven donaties zitten, daarbij achterwege blijven.

\subsection{Beoordeling}

De vermelding in de Europese verdragen van politieke partijen op Europees niveau is een erkenning van het belang van die partijen door de Europese wetgever. Met Verordening 2004/2003 betreffende het statuut en de financiering van politieke partijen op Europees niveau is daarnaast een stap gezet naar meer financiële zelfstandigheid van de Europartijen. Zij moeten daardoor beter in staat worden geacht om een eigen positie te creëren binnen het Europese integratieproces. Toch laat Verordening 2004/2003 nog een aantal belangrijke zaken ongeregeld waardoor ze op onderdelen meer van symbolische dan van praktische betekenis lijkt.

In de eerste plaats ziet de regeling slechts op politieke partijen die voldoen aan de in de verordening vastgelegde criteria. Niet iedere parlementariër in het Europees Parlement is echter gelieerd aan een dergelijke partij en ook niet iedere fractie. Een voorbeeld is de Europese tak van de Partij van de Vrijheid (PVV). De vier (straks vijf) leden van de PVV die momenteel zitting hebben in het Europees Parlement worden getypeerd als 'niet-ingeschrevenen', ${ }^{275}$ wat zoveel betekent als: niet aangesloten bij

272 Voerman 2009, p. 2I2.

273 Vgl. Voerman 2009, p. 2 I2.

274 Zie hierover verder Voerman 2009, p. 213.

275 Van de 736 leden van het Europees Parlement zijn er 28 leden gekwalificeerd als niet-ingeschrevenen; deze leden zijn dan ook niet verbonden met een Eurofractie die gelieerd is aan een politieke partij op Europees niveau, zie voor een overzicht: http://www.europarl.europa.eu/members/expert/groupAndCountry.do?language $=$ NL. 
een Eurofractie die allianties heeft met een Europartij. De Europese tak van de PVV is vooral verbonden met de Nederlandse PVV. Zou de PVV subsidie van de Europese Unie willen ontvangen, dan zou zij moeten voldoen aan de criteria van Verordening 2004/2003. Gelet op haar houding tegenover subsidiëring in Nederland, zal de partij daar vermoedelijk weinig voor voelen. Het voorbeeld toont een zwak punt van de verordening. Alleen die partijen die op basis van de verordening kunnen worden gekwalificeerd als Europartij en die financiering ontvangen uit de Europese middelen moeten voldoen aan de transparantieverplichtingen en aan de verboden van bepaalde typen partijfinanciering.

In de tweede plaats lijkt Verordening 2004/2003 eenzelfde omissie te hebben als de Nederlandse Wet subsidiëring politieke partijen: er is in de verordening geen sanctie voorzien voor het geval een Europartij geen openheid van zaken ten aanzien van zijn financiering geeft. Hetzelfde geldt voor het geval dat een Europartij een door de verordening verboden donatie aanneemt, tenzij we moeten aannemen dat in zo'n geval de volledige aanspraak op subsidie vervalt. Het gebrek aan een sanctiestelsel met sancties van oplopend gewicht, doet afbreuk aan de effectiviteit van de verordening.

Ten slotte ziet Verordening 2004/2003 alleen op de transparantie van de financiering van Europartijen en niet op die van de individuele leden van het Europees Parlement. De ervaring leert dat beide nodig zijn om tot een volledig beeld te komen.

De ontwikkeling en structuur van de Europartijen is enig in zijn soort. Het Verdrag van Lissabon, het Handvest van de grondrechten van de Europese Unie en Verordening 2004/2003 inzake het statuut en de financiering van de politieke partijen op Europees niveau hebben bijgedragen tot een intensivering van de samenwerking tussen de politieke partijen van de nationale lidstaten in de Europartijen. Van een zelfstandige positie van de nationale partijen is vooralsnog echter geen sprake, de banden tussen de nationale partijen en de vertegenwoordigers van het Europees Parlement blijven groot. Op het mobiliseren van kiezers en het ontwikkelen van EUbrede verkiezingsprogramma's lijken de Europartijen zich ook niet erg te richten. Ze zijn daardoor niet vergelijkbaar met de partijen zoals we die vanuit de nationale context kennen. Ze vormen vooral handzame constructies ten behoeve van de samenwerking bij financiering en besluitvorming. Of die samenwerking steeds ook de geloofwaardigheid vergroot, blijft de vraag. Partijen die nationaal tegenover elkaar staan, maken in Europees verband soms deel uit van dezelfde Europartij en dezelfde fractie in het Europees parlement. Dat wekt verwarring, omdat de band tussen het Europees electoraat en de volksvertegenwoordiger in het Europees Parlement vooralsnog door de nationale politieke partijen wordt gelegd en niet door de politieke partijen op Europees niveau. ${ }^{276}$

276 Vgl. ook Zotti 20Io, p. I05 en Bardi 2006, p. I3. 


\section{Lijst van verkort aangehaalde literatuur}

Asser-Maeijer 1997: Mr. C. Asser's Handleiding tot de beoefening van het Nederlands burgerlijk recht, Vertegenwoordiging en rechtspersoon. De rechtspersoon, achtste druk, bewerkt door J.M.M. Maeijer, Deventer 1997 .

Bannier 1936: G.W. Bannier, Grondwetten van Nederland: teksten der achtereenvolgende staatsregelingen en grondwetten sedert 1795 , met verschillende andere staatsstukken, historische toelichtingen en eenige tabellen, Zwolle 1936.

Bardi 2006: L. Bardi, EU enlargement, European Parliament Elections and Transnational Trends in European Parties, in: European View, nr. 3, 2006, p. 13-20.

Barkhuysen 2004: Tom Barkhuysen, Politieke participatie van discriminerende partijen: ondersteunen, gedogen of bestrijden? in: NJCM-bulletin, jrg. 29, nr. 4b, p. 596-605.

Van den Bergh 1936: G. van den Bergh, De democratische staat en de niet-democratische partijen (intreerede 1936), in: G. van den Bergh, Verzamelde staatsrechtelijke opstellen (eerste deel), Alphen aan den Rijn I949, p. I-2I.

Boogman 1978: J.C. Boogman, Rondom 1848. De politieke ontwikkeling van Nederland 1840-1858, Bussum, 1978 .

Bovend'Eert \& Kummeling 2004: P.T.T. Bovend'Eert en H.R.B.M. Kummeling, Het Nederlandse parlement, Deventer, 2004.

Brems 2009: Eva Brems, Botsende grondrechten. Over politieke partijen die discrimineren, artikel-I-lezing, Utrecht, I3 maart 2009, in: Tijdschrift voor Bestuurswetenschappen en Publiekrecht, 2009/8, p. 45I-460.

De Bruijn 2005: J. de Bruijn, Het boetekleed ontsiert de man niet, Abraham Kuyper en de lintjesaffaire, Amsterdam 2005.

Burgerforum 2006: Burgerforum Kiesstelsel, Met één stem meer keus. Advies over het toekomstige kiesstelsel. Het advies is te vinden door op de website www.rijksoverheid.nl te zoeken naar: Eindadvies Burgerforum.

Burkens I971: M.C.B. Burkens, Beperking van grondrechten, Deventer I97I.

Burkens 1989: M.C. Burkens, Algemene leerstukken van grondrechten naar Nederlands constitutioneel recht, Zwolle ig8g.

Burkens 200I: M.C. Burkens, H.R.B.M. Kummeling, B.P. Vermeulen \& R.J.G.M. Widdershoven, Beginselen van de democratische rechtstaat, vijfde druk, Deventer $200 I$.

Busstra 2008: M.J. Busstra, De afweging gewogen. Een analyse van twee tegenstrijdige uitspraken ten aanzien van de SGP en het vrouwenkiesrecht, in: Rechtsgeleerd Magazijn Themis, jrg. I69, nr. 6, december 2008, p. 235-242.

Buys \& Groeneveld-Louwerse I996: S.G.M. Buys \& J.G. Groeneveld-Louwerse, Politieke partijen: publieke activiteiten privaatrechtelijk gekaderd of gekneveld?, in: Stichting \& Vereniging I996, p. I03-II2.

Van Dijk \& Van Hoof 20o6: P. van Dijk, F. van Hoof, A. van Rijn \& L. Zwaak (red.), Theory and Practice of the European Convention on Human Rights, fourth edition, Antwerpen-Oxford 2006.

Dölle ig8r: A.H.M. Dölle, Het fractiereglement, in: Beleid en Maatschappij, jrg. 8, nr. 5, mei I98I, p. 156-I62.

Dölle 2006: A.H.M. Dölle, De SGP onder vuur, in: Documentatiecentrum Nederlandse Politieke Partijen, Jaarboek 2005, Groningen 2006, p. 99-I22. 
Van Doorn 2009: J.A.A. van Doorn, Herfsttij der democratie - Over de huidige malaise in de Nederlandse politiek, in: J.A.A. van Doorn, Nederlandse democratie. Historische en sociologische waarnemingen, Amsterdam 2009, p. 475-517.

Dragstra 2008: L. Dragstra, Enige opmerkingen over partijfinanciering. De regelgeving voor publieke en private financiering van politieke partijen in Nederland en Duitsland nader bekeken en beoordeeld, dissertatie, Nijmegen 2008.

Elzinga 1982: D.J. Elzinga, De politieke partij en het constitutionele recht, dissertatie, Nijmegen 1982.

Elzinga 1997: D.J. Elzinga, Het Nederlandse kiesrecht, Deventer 1997.

Elzinga 2004: D.J. Elzinga, De toekomst van de vertegenwoordigende partijendemocratie, in: De ontwikkeling en toekomst van de vertegenwoordigende democratie. Staatsrechtconferentie 2003, Deventer 2004, p. I-27.

Elzinga 2006: D.J. Elzinga, Cessieovereenkomsten met SP zijn rechtens nietige verbintenissen, in: De Gemeentestem 2006, nr. I48.

Elzinga 2008: D.J. Elzinga, Politieke partijen dienen een minimum aan interne partijdemocratie te bezitten: pro en contra, in: Ars Aequi, juni 2008, p. 422-423.

Elzinga \& Wisse I988: D.J. Elzinga \& C. Wisse, De parlementaire fracties, Groningen I 888.

Eskes I988: J.A.O. Eskes, Repressie van politieke bewegingen in Nederland, dissertatie, Zwolle 1988.

Goodin 2008: Robert E. Goodin, Innovating democracy. Democratic Theory and Practice After the Deliberative Turn, Oxford 2008.

Groenman 1997: L.S. Groenman e.a., Het Vrouwenverdrag in Nederland anno 1997. Verslag van de commissie voor de eerste nationale rapportage over de implementatie in Nederland van het Internationaal Verdrag tegen Discriminatie van Vrouwen, Den Haag 1997. Te raadplegen op de website www.vrouwenverdrag.nl.

Haffner 2003: Sebastian Haffner, Geschichte eines Deutschen. Die Erinnerungen 1914-1933, Stuttgart, 2003.

Hertogh \& Zoontjens 2006: M.L.M. Hertogh \& P.J.J. Zoontjens (red.), Gelijke behandeling: principes en praktijken. Evaluatieonderzoek Algemene wet gelijke behandeling, Nijmegen 2006.

Van der Hulst 2000: Marc van der Hulst, The Parliamentary Mandate. A global comparativestudy, Interparliamentary Union, Genève 2000.

Huart 1925: F.J.A. Huart, Grondwetsherziening 1917 en 1922, Arnhem, I925.

Hix 1996: S. Hix, The transnational party federations, in: John Gaffney (ed.), Political parties and the European Union, London/New York, I996, 308-331.

Hix \& Lord I997: S. Hix \& C. Lord, Political Parties in the European Union, Basingstoke, I997.

Koekkoek 2000: A.K. Koekkoek (red.), De Grondwet, derde druk, Deventer 2000.

Koole I992: Ruud Koole, De opkomst van de moderne kaderpartij. Veranderende partijorganisatie in Nederland 1960-1990, dissertatie, Utrecht 1992.

Koole 1995: R. Koole, Politieke partijen in Nederland: ontstaan en ontwikkeling van partijen en partijstelsel, Utrecht 1995.

Koole 200I: R. Koole, Interne partijdemocratie en representatie, in: Documentatiecentrum Nederlandse Politieke Partijen, Jaarboek 2000, Groningen 200I, p. 4I-59.

Koole 2006: Ruud Koole, Lijsttrekkersverkiezingen in Nederlandse politieke partijen, in: Beleid en Maatschappij, jrg. 33, nr. 4, oktober 2006, p. 253-265. 
Koole 2006b: R.A. Koole, Politiek en tegenpolitiek in de Nederlands democratie. Politici, journalisten en wetenschappers in de ban van het populisme, oratie, Leiden 2006.

Koole 2007: R. Koole, Beweging is net zo goed politieke partij. Ledenpartijen zijn beter voor de democratie dan partijen zonder leden, in: NRC Handelsblad, 3I oktober 2007.

Koole 2008: R. Koole, Nieuwe regels voor politieke financiën, in: Tijdschrift voor Socialisme en Democratie, nr. $7 / 8,2008$, p. 46-59.

Koopmans I992: T. Koopmans, Verbod van politieke partijen? In: Rechtsgeleerd Magazijn Themis $1992 / 7$, p. 263.

Kortmann 1987: C.A.J.M. Kortmann, De Grondwetsherzieningen 1983 en 1987, Deventer 1987.

Kortmann 2008: C.A.J.M. Kortmann, Constitutioneel recht, Deventer 2008.

Kortmann 2008b: C.A.J.M. Kortmann, Subsidie en vrouwen. Annotatie bij Afdeling bestuursrechtspraak Raad van State, 5 december 2007, LJN: BB9493, nr. 200609224/I, in: Ars Aequi, april 2008, p. 29I-297.

Kranenburg 1928: R. Kranenburg, Positief Recht en Rechtsbewustzijn, Groningen, I928.

Kuyper I879: A. Kuyper, Ons program, Amsterdam I879.

Ladrech 2002: R. Ladrech, Party of European Socialists, in: K.M. Johansson en P. Zervakis (red.), European Political Parties between Cooperation and Integration, Baden-Baden 2002, p. 8I-95.

Loots 2004: J. Loots, Voor het volk, van het volk: van districtenstelsel naar evenredige vertegenwoordiging, dissertatie, Amsterdam 2004.

Löwensteyn I982: F.J.W. Löwensteyn, Het recht van Vereniging/Het Verenigingsrecht; in: A.K. Koekkoek e.a. (red.), Grondrechten. Commentaar op Hoofdstuk 1 van de herziene Grondwet (Jeukensbundel), Nijmegen I982, p. I9I-208.

Lucardie 200I: A.P.M. Lucardie, Representatie zonder partijen: de vergeten alternatieven, in: Documentatiecentrum Nederlandse Politieke Partijen, Jaarboek 2000, Groningen 200I, p. 75-100.

Lucardie 2006: Paul Lucardie, Arjan Marchand en Gerrit Voermans, Frictie in de fractie, in: Eliora Van der Hout, Wytze van der Woude en Gerrit Voerman (red.), Representatie, fractiediscipline en financiering, Den Haag 2006, p. 59-I68.

Lucardie \& Voerman 2008: Paul Lucardie en Gerrit Voerman, Overzicht van de partijpolitieke gebeurtenissen van het jaar 2007, in: Documentatiecentrum Nederlandse Politieke Partijen, Jaarboek 2007, Groningen 2008.

De Monchy 20I0: De Monchy en Snijder-Kuipers, Groene Serie Rechtspersonen, Boek 2 BW, Aantekening 3, Kluwer 2010.

Moschonas 2004: G. Moschonas, The party of European Socialists. The difficult 'construction' of a European player, in: Delwit, Külahci \& Van de Walle (red.), The Europarties. Organisation and Influence, Brussel 2004, p. II3-I34

Nehmelman 2007: R. Nehmelman, De Grondwet voor het Koninkrijk der Nederlanden, in: H. Battjes en B.P. Vermeulen, Constitutionele klassiekers, Nijmegen 2007.

Nieuwenhuis 2003: A.J. Nieuwenhuis, Partijverbod en supraconstitutionalisme in rechtsvergelijkend perspectief: een drieluik. In: J.L. de Reede en J.H. Reestman (red.), Op het snijulak van recht en politiek, Opstellen aangeboden aan prof. mr. L. Prakke, Deventer 2003, p. 199-213.

Olde Kalter 1979: C.J.G. Olde Kalter, Overheidspersoneel en grondrechten. Geschriften van de Vereniging voor Administratief Recht LXXXIV, Alphen aan den Rijn I979. 
Oomen 2010: Barbara Oomen, Joost Guijt, Iris Meijvogel, Matthias Ploeg en Niels Rijke, Van Walswetten en de Wil van God, in: Nederlands Juristenblad 2010, afl. 4, p. 216-222.

Peters \& Bleeker 2008: Jit Peters en Karin Bleeker, Staat moet SGP aanpakken maar ook subsidiëren, in: Nederlands Juristenblad, nr. 10, 2008, p. 556-563.

Reifen \& Schmitt 1980: K. Reifen \& H. Schmitt, Nine Second Order National Elections: A Conceptual Framework for the Analysis of European Election Results, in: European Journal of Political Research, nr. 8, (1980), p. 3-44.

Van der Pot 1940: C.W. van der Pot, Handboek van het Nederlandse Staatsrecht, Zwolle, 1940.

Van der Pot 2006: Van der Pot, Handboek van het Nederlandse staatsrecht, bewerkt door D.J. Elzinga en R. de Lange m.m.v. H.G. Hoogers, Deventer 2006.

Raad voor het Openbaar Bestuur 2009: Raad voor het Openbaar Bestuur, Democratie vereist partijdigheid, Den Haag 2009.

Van Rooyen \& Voerman 2008: E. van Rooyen en G. Voerman, Het einde van een tijdperk? De PvdA en het verlangen naar Europese partijvorming, in: F. Becker, M. Hurenkamp en M. Sie Dhian Ho (red.), Het ongemak over Europa. Wiarda Beckman Stichting (WBS) jaarboek 2008, p. I46-I64.

Schutgens 2007a: R.J.B. Schutgens, SP mag geen afdracht van politici eisen, in: NRC Handelsblad, 24 augustus 2007.

Schutgens 2007b: R.J.B. Schutgens, Volksvertegenwoordiger en partijafdracht, in: Openbaar bestuur, jrg. 17, nr. II, november 2007, p. 2-7.

Schutgens \& Sillen 2010: Roel Schutgens en Joost Sillen, De SGP, het rechterlijk bevel en het kiesrecht, in: Nederlands Juristenblad, 30 april 20I0, afl. I7, p. III4-III7.

Simons I966: D. Simons, Twintig jaar later, Alphen aan den Rijn, Ig66.

Thomassen \& Andeweg 2006: J.J.A. Thomassen en R.B. Andeweg, Fractiediscipline: vooroordelen en misverstanden, in: Documentatiecentrum Nederlandse Politieke Partijen, Jaarboek 2005, Groningen 2006.

Tromp 2002: Bart Tromp, Een partijloze democratie, of: het einde van de politieke partij? in: S. Noorda e.a. Haagse tegenstrijdigheden. Vier essays over burgers, overheid en politieke partijen, Amsterdam 2002, p. 53-70.

Venice Commission 1999: Venice Commission, Guidelines on prohibition and dissolution of political parties and analogous measures, Straatsburg, I5 December 1999, CDL-INF (99) I5.

Venice Commission 200I: Venice Commission, Guidelines and Report on the Financing of Political Parties, Straatsburg 23 maart 200I, CDL-INF (200I) 8.

Venice Commission 2004: Venice Commission, Guidelines on Legislation on Political Parties: some Specific Issues, Straatsburg, 25 februari 2004, CDL-DEM (2003) 4 rev.

Venice Commission 2006: Venice Commission, Report on the Participation of Political Parties in Elections, Straatsburg, I4 juni 2006, CDL-AD (2006) 025.

Venice Commission 2007: Venice Commission, Opinion on the law on amendments to the legislation concerning the status of deputies of the Verkhouna Rada of the autonomous republic of Crimea and of local councils in Ukraine, Straatsburg 5 juni 2007, CDL-AD (2007) or8.

Venice Commission 2009: Venice Commission, Opinion on the constitutional and legal provisions relevant to the prohibition of political parties in Turkey, Straatsburg 13 maart 2009, CDL-AD (2009) 006.

Venice Commission 2009a: Venice Commission, Code of Good Practice in the Field of Political Parties, Straatsburg, 3 juni 2009, CDL-AD (2009) 02I. 
Venice Commission 2009b: Venice Commission, Report on the imperative mandate and similar practices, Straatsburg I6 juni 2009, CDL-AD (2009) 027.

Voerman 1994: Gerrit Voerman (red.), Politiek zonder partijen? Over de horizon van partijpolitiek, Amsterdam 1994 .

Voerman 2005: G. Voerman, Plebiscitaire partijen? Over de vernieuwing van de Nederlandse partijorganisaties, in: Documentatiecentrum Nederlandse Politieke Partijen, Jaarboek 2004, Groningen 2005.

Voerman 2009: G. Voerman, Partijformaties op Europees niveau. Van federaties naar Europartijen, in: Documentatiecentrum Nederlandse Politieke Partijen, Jaarboek 2007, Groningen 2009, p. I9I-22I.

Vogel 2009: H.H. Vogel, Prohibition of political parties in Germany, rapport voor de conferentie Constitutional Restrictions of Freedom of Association in Belgrado, 2 juni 2009, gepubliceerd door de Venice Commission, Straatsburg, r juli 2009, CDL-JU(2009)052.

Zotti 20ro: Stefan Zotti, Politische Parteien auf europäischer Ebene, Grundzüge der politischen und rechtlichen Entwicklung des europäischen Parteiensystems, BadenBaden 20I0. 